The Alaska Volcano Observatory is a cooperative program of the U.S. Geological Survey, University of Alaska Fairbanks Geophysical Institute, and the Alaska Division of Geological and Geophysical Surveys. The Alaska Volcano Observatory is funded by the U.S. Geological Survey Volcano Hazards Program and the State of Alaska.

\title{
2008 Volcanic Activity in Alaska, Kamchatka, and the Kurile Islands: Summary of Events and Response of the Alaska Volcano Observatory
}

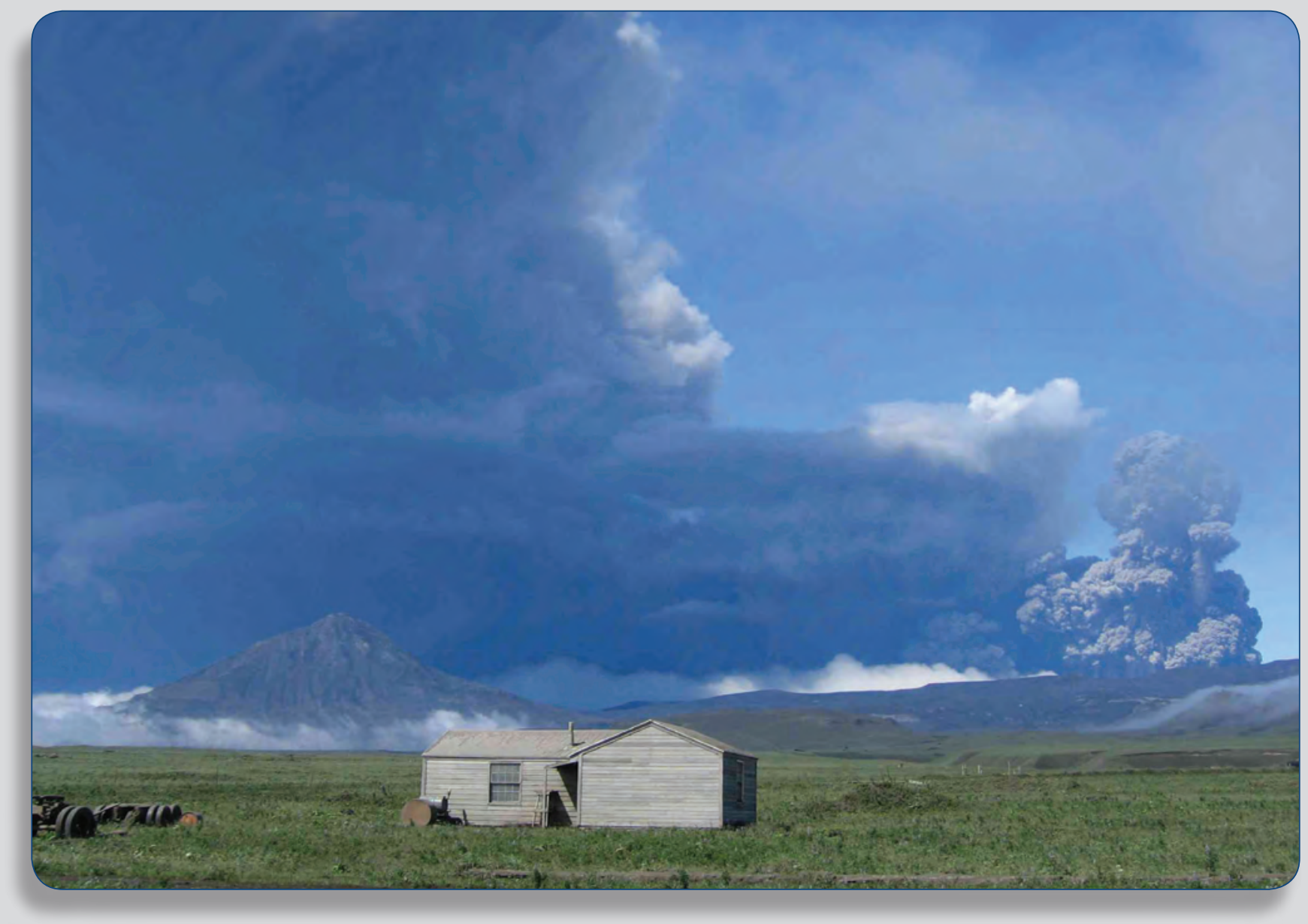

Scientific Investigations Report 2010-5243 
Cover: Photograph showing Okmok eruption plume as seen from Fort Glenn (ranch building in foreground) on August 3, 2008. Ash from this phase of the eruption ultimately reached the community of Nikolski on the west end of Umnak Island. Photograph by J. Larsen, AVO/UAFGI. 


\section{Volcanic Activity in Alaska, Kamchatka, and the Kurile Islands: Summary of Events and Response of the Alaska Volcano Observatory}

By Christina A. Neal, Robert G. McGimsey, James P. Dixon, U.S. Geological Survey, Cheryl E. Cameron, Alaska Department of Geological and Geophysical Surveys, Anton A. Nuzhdaev, Institute of Volcanology and Seismology, and Marina Chibisova, Institute of Marine Geology and Geophysics

The Alaska Volcano Observatory is a cooperative program of the U.S. Geological Survey, University of Alaska Fairbanks Geophysical Institute, and the Alaska Division of Geological and Geophysical Surveys. The Alaska Volcano Observatory is funded by the U.S. Geological Survey Volcano Hazards Program and the State of Alaska.

Scientific Investigations Report 2010-5243 


\section{U.S. Department of the Interior \\ KEN SALAZAR, Secretary \\ U.S. Geological Survey \\ Marcia K. McNutt, Director}

\section{U.S. Geological Survey, Reston, Virginia: 2011}

For more information on the USGS - the Federal source for science about the Earth, its natural and living resources, natural hazards, and the environment, visit http://www.usgs.gov or call 1-888-ASK-USGS

For an overview of USGS information products, including maps, imagery, and publications, visit http://www.usgs.gov/pubprod

To order this and other USGS information products, visit http://store.usgs.gov

Any use of trade, product, or firm names is for descriptive purposes only and does not imply endorsement by the U.S. Government.

Although this report is in the public domain, permission must be secured from the individual copyright owners to reproduce any copyrighted materials contained within this report.

Suggested citation:

Neal, C.A., McGimsey, R.G., Dixon, J.P., Cameron, C.E., Nuzhdaev, A.A., and Chibisova, Marina, 2011, 2008 Volcanic activity in Alaska, Kamchatka, and the Kurile Islands: Summary of events and response of the Alaska Volcano Observatory: U.S. Geological Survey Scientific Investigations Report 2010-5243, 94 p. 


\section{Contents}

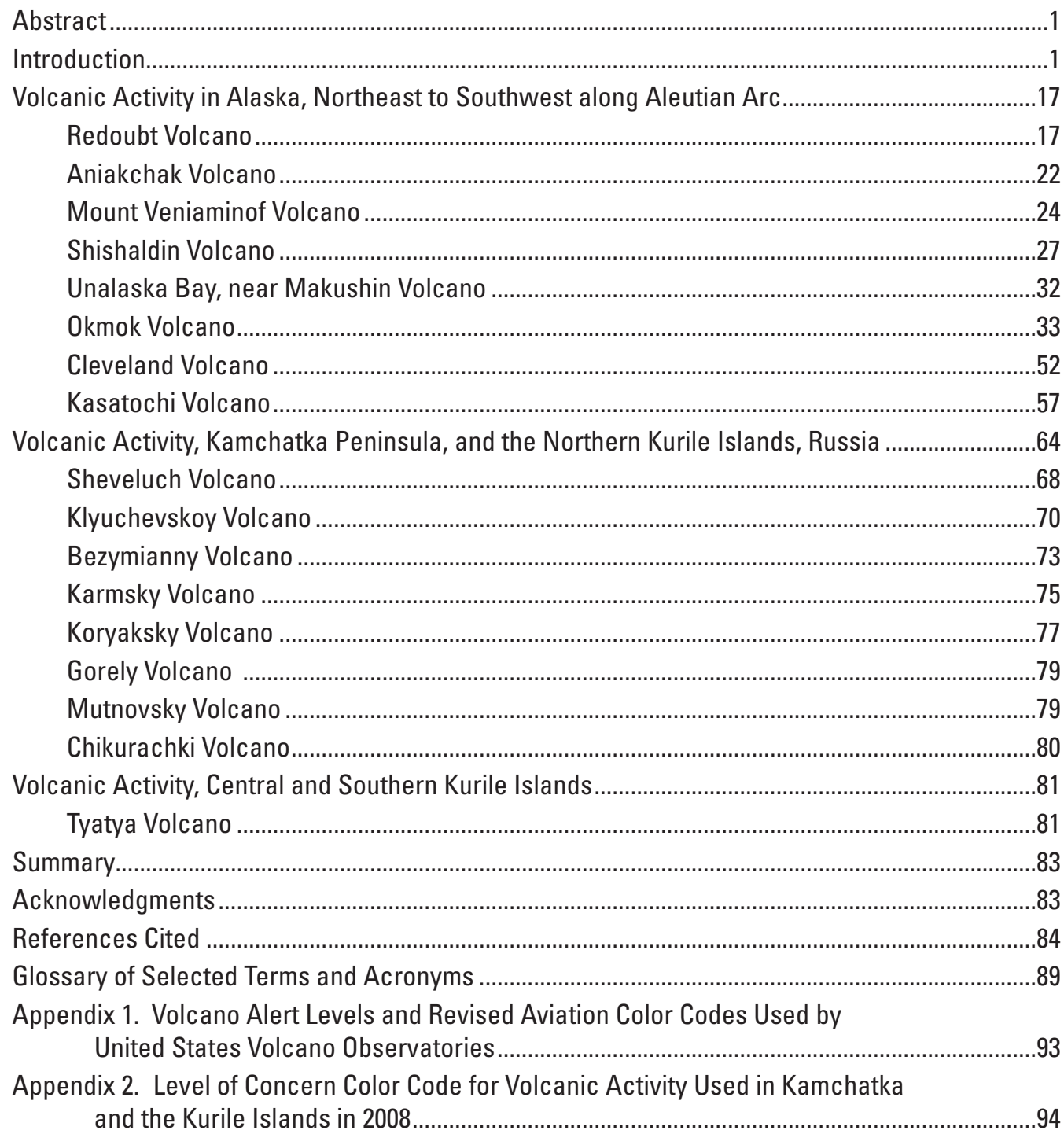




\section{Figures}

Figure 1. Map showing historically active volcanoes in Alaska along with place names used in this report

Figure 2. Graph showing number of earthquakes located per year in the AVO annual catalogs of seismicity and number of seismically monitored volcanoes per year

Figure 3. Photograph showing fumarolic activity through glacial ice that covered the 1990 lava dome in the summit crater of Redoubt, August 7, 2008

Figure 4. Map showing location of Redoubt Volcano in south-central Alaska, other volcanoes, and place names in this section

Figure 5. Photograph showing summit area and upper north flank of Redoubt Volcano ...... 20

Figure 6. Photograph showing an active cascade of water - about $40 \mathrm{~m}(130 \mathrm{ft})$ in height - and debris from atop the Drift glacier at the north base of Redoubt Volcano, November 7, 2008.

Figure 7. Photograph showing aerial view of the western portion of $10-\mathrm{km}$-diameter (6.2 mi) Aniakchak caldera on the Alaska Peninsula .... 23

Figure 8. Photograph showing small ash emission event at Veniaminof Volcano .......... 25

Figure 9. Seismicity related to the small 09:03 AKDT ash emission event at

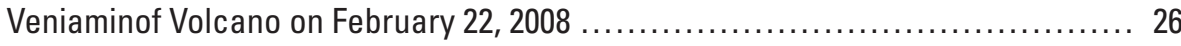

Figure 10. Photograph showing summit area of Shishaldin Volcano on August 1, 2008....... 28

Figure 11. Photograph showing summit crater of Shishaldin Volcano on August 1, 2008 ..... 29

Figure 12. Photograph showing a particularly spectacular vapor plume from the

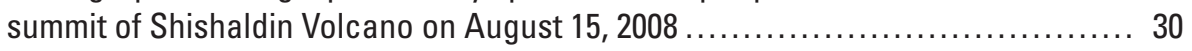

Figure 13. Photograph showing summit crater of Shishaldin Volcano on October 12, 2008 _.. 31

Figure 14. Photograph showing aerial view of Okmok Caldera, June 7, 2007.............. 33

Figure 15. Thermal infrared channel from the July 12, 2008, 22:12 UTC GOES satellite image showing the eastward drifting 0kmok eruption cloud $\ldots \ldots \ldots \ldots \ldots \ldots . \ldots 35$

Figure 16. Photograph showing Okmok Caldera in eruption on July 20, $2008 \ldots \ldots \ldots \ldots \ldots \ldots . \ldots 39$

Figure 17. Photograph showing 2008 Crater Creek lahar deposit delta and sediment plume into the Bering Sea ....................................... 40

Figure 18. Photograph showing active vents within Okmok Caldera on August 1, 2008....... 41

Figure 19. Photograph showing Okmok Volcano in eruption on August 2, $2008 \ldots \ldots \ldots \ldots \ldots . \ldots 2$

Figure 20. Photograph showing Okmok eruption plume as seen from Fort Glenn on August 3, 2008 43

Figure 21. Photograph showing eruption cloud at 0kmok on August 13, $2008 \ldots \ldots \ldots \ldots \ldots . \ldots 4$

Figure 22. Photograph showing new tephra cone-approximately $100-200 \mathrm{~m}(330-660 \mathrm{ft})$ high — with a summit crater about 750-800 $\mathrm{m}(2,460-2,620 \mathrm{ft})$ in diameterperched on the northeast flank of Cone $D$.....

Figure 23. Photograph showing stratigraphic section JFLOK016 on the northeast rim

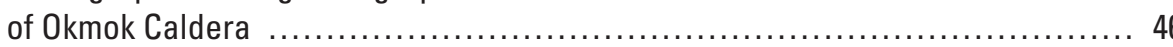

Figure 24. Photograph showing post-eruption oblique aerial view to the southeast across the caldera.

Figure 25. Sketch map showing principle features of the 2008 eruption atop topography and a geologic map of part of the Okmok caldera ....

Figure 26. Photograph showing new tephra cone formed over the longest-lived vent of the 2008 eruption 


\section{Figures-Continued}

Figure 27. Photograph showing collapse pits (circled area) in a zone extending southwest-northeast of Cone D.

Figure 28. Close-up view of Advanced Spaceborne Thermal Emission and Reflection Radiometer (ASTER) daytime visible and thermal infrared (TIR) imagery acquired at 22:29 UTC (2:29 PM AKDT) on April 24, 2008, showing continuing volcanic activity at Cleveland

Figure 29. Photograph showing ash and bombs erupting from the summit of Cleveland volcano as observed from the F/V Lady Gudny, July 21, 2008

Figure 30. Photograph showing a dusting of ash from Cleveland volcano on the deck of the F/V Lady Gudny, July 21, 2008

Figure 31. Photograph showing steam rising from a blocky deposit produced during explosive activity at Cleveland volcano on July 21, 2008

Figure 32. Map showing location of Kasatochi Volcano in the central Aleutians

Figure 33. Photograph showing tephra-fall deposit on the F/V Larisa M., which was about $13 \mathrm{~km}(8 \mathrm{mi}$ ) and traveling west from the volcano during a 1.5-3 hour period of intense tephra fall

Figure 34. AVHRR image of the Kasatochi eruption cloud caught in a counter-clockwise rotating low-pressure system in the north Pacific....

Figure 35. Photograph showing aerial view of the southwest flank of Kasatochi Volcano,

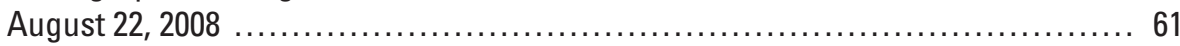

Figure 36. Photographs showing Kasatochi Volcano before and after the 2008 eruption ...... 62

Figure 37. Map showing Kamchatka Peninsula and the northern Kurile Islands of Alaid and Paramushir 65

Figure 38. Photograph showing ash cloud rising from a pyroclastic avalanche off the active lava dome at Sheveluch Volcano, September 13, 2008

Figure 39. Photograph showing a lava flow descending the Krestovskay channel on the northwest flank of Klyuchevskoy Volcano, December 10, 2008

Figure 40. Photograph showing small phreatic explosions and ash clouds forming as lava flowing down the northwest flank of Klyuchevskoy Volcano interacts with glacial ice, December 12, 2008

Figure 41. Photograph showing view of the west flank of Bezymianny Volcano on July 20, 2008

Figure 42. Photograph showing typical explosive activity at Karymsky Volcano on April 23, 2008

Figure 43. Photograph showing ash cloud and deposits of ash on the northwestern flank of Koryaksky Volcano, December 26, 2008

Figure 44. Photograph showing vigorous fumarolic plume reaching about $4.5 \mathrm{~km}$ ASL $(14,800 \mathrm{ft})$ from Koryaksky Volcano as seen from the Institute of Volcanology and Seismology in Petropavlovsk on January 10, 2009. View is to the north ....

Figure 45. Photograph showing an ash and gas cloud drifting to the southeast from Chikurachki Volcano on August 2, 2008 80

Figure 46. Map of Kurile Island Volcanoes with place names used in this report ............. 82

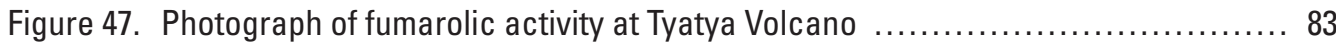




\section{Tables}

Table 1. History of seismic monitoring of Alaskan volcanoes from August 1971 through

December 2008

Table 2. Summary of 2008 VOLCANIC ACTIVITY in Alaska, including actual eruptions, possible eruptions, and unusual increases in seismicity or fumarolic activity ..... 6

Table 3. Alaskan volcanoes with Color Code changes in $2008 \ldots \ldots \ldots \ldots \ldots \ldots \ldots \ldots \ldots \ldots$

Table 4a. Compilation by year of volcanoes included in an Alaska Volcano Observatory Annual Summary, 1992-2008 .....

Table 4b. Compilation by volcano for particular years included in an Alaska Volcano Observatory Annual Summary, 1992-2008

Table 4c. Citations for Alaska Volcano Observatory Annual Summary reports, 1992-2008 ... 14

Table 5. Preliminary chronology of major events and selected formal Alaska Volcano Observatory notifications pertaining to the 2008 eruption of $0 \mathrm{kmok}$....

Table 6. Preliminary chronology of major events and selected formal Alaska Volcano Observatory notifications pertaining to the 2008 eruption of Kasatochi volcan. ... 63

Table 7. Seismically monitored volcanoes of Kamchatka as of December 2008 .......... 66

Table 8. Summary of VOLCANIC ACTIVITY on Kamchatka Peninsula and in the Kurile Islands, Russia, 2008 67

Table 9. Kamchatkan volcanoes with Color Code changes in 2008 67 


\title{
Conversion Factors and Datum
}

\author{
Conversion Factors
}

Inch-Pound to SI

\begin{tabular}{lcl}
\hline \multicolumn{1}{c}{ Multiply } & \multicolumn{1}{c}{ By } & \multicolumn{1}{c}{ To obtain } \\
\hline acre & 4,047 & square meter $\left(\mathrm{m}^{2}\right)$ \\
cubic mile $\left(\mathrm{mi}^{3}\right)$ & 4.168 & cubic kilometer $\left(\mathrm{km}^{3}\right)$ \\
foot $(\mathrm{ft})$ & 0.000305 & kilometer $(\mathrm{km})$ \\
foot $(\mathrm{ft})$ & 0.3048 & meter $(\mathrm{m})$ \\
inch (in.) & 2.54 & centimeter $(\mathrm{cm})$ \\
inch (in.) & 25.4 & millimeter $(\mathrm{mm})$ \\
mile (mi) & 1.609 & kilometer $(\mathrm{km})$ \\
\hline
\end{tabular}

Temperature in degrees Fahrenheit $\left({ }^{\circ} \mathrm{F}\right)$ may be converted to degrees Celsius $\left({ }^{\circ} \mathrm{C}\right)$ as follows:

$$
{ }^{\circ} \mathrm{C}=\left({ }^{\circ} \mathrm{F}-32\right) / 1.8
$$

SI to Inch-Pound

\begin{tabular}{lcl}
\hline \multicolumn{1}{c}{ Multiply } & \multicolumn{1}{c}{ By } & \multicolumn{1}{c}{ To obtain } \\
\hline cubic kilometer $\left(\mathrm{km}^{3}\right)$ & 0.2399 & cubic mile $\left(\mathrm{mi}^{3}\right)$ \\
kilometer $(\mathrm{km})$ & 0.6214 & mile $(\mathrm{mi})$ \\
kilometer $(\mathrm{km})$ & 3,281 & foot $(\mathrm{ft})$ \\
square kilometer $\left(\mathrm{km}^{2}\right)$ & 0.3861 & square mile $\left(\mathrm{mi}^{2}\right)$ \\
meter $(\mathrm{m})$ & 3.281 & foot $(\mathrm{ft})$ \\
centimeter $(\mathrm{cm})$ & 0.3937 & inch (in.) \\
metric ton per day & 1.1022 & ton per day (ton/d) \\
millimeter $(\mathrm{mm})$ & 0.03937 & inch (in.) \\
\hline
\end{tabular}

Temperature in degrees Celsius $\left({ }^{\circ} \mathrm{C}\right)$ may be converted to degrees Fahrenheit $\left({ }^{\circ} \mathrm{F}\right)$ as follows:

$$
{ }^{\circ} \mathrm{F}=\left(1.8 x^{\circ} \mathrm{C}\right)+32 .
$$

Datum

Altitude and elevation as used in this report, refers to distance above sea level, unless otherwise noted. 
viii

This page is intentionally left blank. 


\title{
2008 Volcanic Activity in Alaska, Kamchatka, and the Kurile Islands: Summary of Events and Response of the Alaska Volcano Observatory
}

\author{
By Christina A. Neal1, Robert G. McGimsey', James P. Dixon², Cheryl E. Cameron³, Anton A. Nuzhdaev4, and \\ Marina Chibisova ${ }^{5}$
}

\section{Abstract}

The Alaska Volcano Observatory (AVO) responded to eruptions, possible eruptions, and volcanic unrest or suspected unrest at seven separate volcanic centers in Alaska during 2008. Significant explosive eruptions at Okmok and Kasatochi Volcanoes in July and August dominated Observatory operations in the summer and autumn. AVO maintained 24-hour staffing at the Anchorage facility from July 12 through August 28. Minor eruptive activity continued at Veniaminof and Cleveland Volcanoes. Observed volcanic unrest at Cook Inlet's Redoubt Volcano presaged a significant eruption in the spring of 2009. AVO staff also participated in hazard communication regarding eruptions or unrest at nine volcanoes in Russia as part of a collaborative role in the Kamchatka and Sakhalin Volcanic Eruption Response Teams.

\section{Introduction}

The Alaska Volcano Observatory (AVO) monitors, studies, and warns of volcanic unrest at Alaskan volcanoes. In 2008, major eruptions at Okmok and Kasatochi Volcanoes dominated AVO's response and scientific efforts. AVO also responded to minor volcanic unrest at several other volcanoes in Alaska (igg. 1).
As of December 31, 2008, 31 of the 52 historically active volcanoes in Alaska are instrumented with a network of seismometers sufficiently reliable in their operation to detect and track earthquake activity (fig. 1). Seismic stations also are in place at two additional volcanoes (Little Sitkin and Semisopochnoi; fig. 1); however, telemetry links are intermittent and thus, AVO does not consider these volcanoes formally monitored with seismic instrumentation. AVO's volcano monitoring program also includes twice-daily analysis of satellite imagery, web cameras, occasional overflights, airborne-gas measurements, and compilation of pilot reports (PIREPS) and observations of local residents and mariners. In addition, AVO receives real-time deformation data from permanent Global Positioning System (GPS) stations at four Alaskan volcanoes (Okmok, Augustine, Akutan, and Mount Spurr). In recent years, periodic analysis of Interferometric Synthetic Aperture Radar (InSAR) imagery also has been used to detect deformation at volcanoes in Alaska (for example, Lu, 2007).

AVO also participates in satellite monitoring of Russian volcanoes and assists in disseminating hazard information on behalf of the Kamchatkan Volcanic Eruption Response Team (KVERT; Kirianov and others, 2002; Neal and others, 2009a) and the Sakhalin Volcanic Eruption Response Team (SVERT; Rybin and others, 2004; Neal and others, 2009a). In 2008, AVO assisted in broadcasting alerts about eruptive activity at five volcanoes in Kamchatka (Sheveluch, Klyuchevskoy, Bezymianny, Karymsky, and Koryaksky) and one in the northern Kurile Islands (Chikurachki).

\footnotetext{
${ }^{1}$ U.S. Geological Survey, Volcano Science Center, Alaska Volcano Observatory, 4200 University Drive, Anchorage, Alaska 99508-4664.

${ }^{2}$ U.S. Geological Survey, Alaska Volcano Observatory, 903 Koyukuk Drive, Fairbanks, Alaska 99775-7320.

${ }^{3}$ Alaska Division of Geological and Geophysical Surveys, College Road, Fairbanks, Alaska 99775.

${ }^{4}$ Kamchatka Volcanic Eruptions Response Team, Institute of Volcanology and Seismology, Piip Boulevard, 9 Petropavlovsk-Kamchatsky, Russia 683006.

${ }^{5}$ Sakhalin Volcanic Eruptions Response Team, Institute of Marine Geology and Geophysics, Nauki Street Yuzhno-Sakhalinsk, Russia 693022.
} 


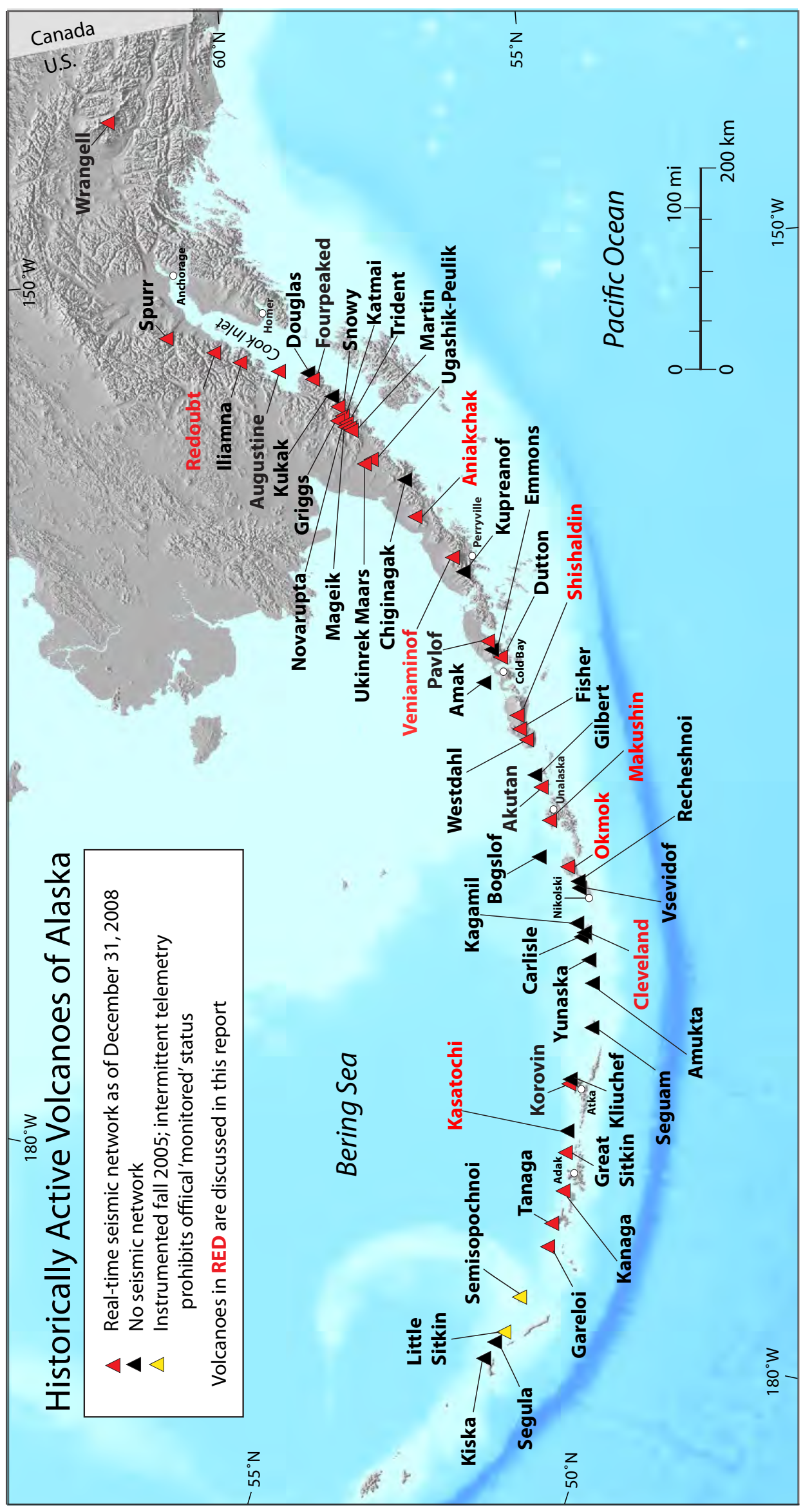

.

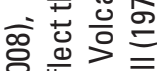

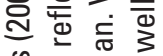

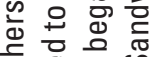

형 d

究离 总

흔.

ब元

志

说范?

उ०

인응

들

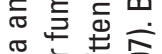

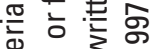

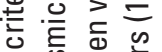

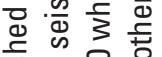

흫 흥응무

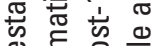

흐음

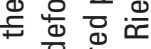

일 के

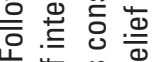

tن응

흥믕

这这更

号的

드응ㅇㅇㅇ

을 힝

농

\&

즏 웡 음

d

음

둔

워

듬웧응

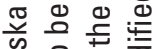

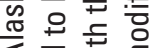

《

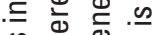

क 흥

훙

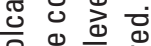

잉 $\frac{0}{3}$

\&

离㐫

元的步

중

응 है

.

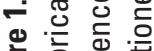

言 总边 
This report summarizes volcanic activity in Alaska, Kamchatka, and the Kuriles in 2008 and briefly describes AVO's operational response. We include information on all volcanoes at elevated alert status and those that prompted significantly increased attention by AVO staff, even if no formal notification of unrest ensued. Descriptions are presented in geographic order from northeast to southwest along the Aleutian Arc, and north to south in the Russian Far East. For each entry, a title block containing the volcanoes unique identifier (CAVW\#) from the Catalog of Active Volcanoes of the World (Simkin and Siebert, 1994) is followed by the volcano's latitude and longitude, summit elevation, and region of occurrence. Each event summary ends with a paragraph of background comments about the volcano in question. Information is derived from published material as well as AVO daily status reports, weekly updates and special information releases, AVO email and online electronic logs, and the Smithsonian Institution Global Volcanism Network Bulletins that are available at http://www.volcano.si.edu/ reports/bulletin/index.cfm. Note that spelling of Russian volcano names may vary slightly from source to source; we use here spellings that have been in use since the early 1990s by AVO, KVERT, and SVERT.

Table 1 is a history of seismic monitoring of Alaskan volcanoes from August 1971 through December 2008. Table 2 summarizes 2008 volcanic activity in Alaska. Table 3 summarizes changes in Color Codes in 2008 for Alaskan volcanoes. Descriptions of Aviation Color Codes and Alert Levels used in Alaska and Russia are presented in appendixes 1 and 2 . Tables 4a, 4b, and 4c present cross-referenced lists of volcanic activity by year and by volcano for this and all previous AVO annual activity reports (1992-2008). Citations for all AVO Annual Summary reports, 1992-2007 also are available at http://www.avo.alaska.edu/ downloads/classresults.php?pregen=annsum.

Altitudes and elevations reported are in feet or meters above sea level (ASL) unless noted otherwise. Time is reported as Alaska Standard Time (AKST), Alaska Daylight Time (AKDT), Kamchatkan Standard Time (KST), or Kamchatkan Daylight Time (KDT) as needed. For most satellite or geophysical instrumentation references, times are given in UTC. We preserve English or Inch-Pound units of measurement especially where they reflect the primary observations of distance or altitude, such as those commonly received via pilot reports and aviation authorities in the United States. Elsewhere, measurements are presented in International System of Units (SI) with approximate conversions to Inch-Pound Units in parentheses for convenience. Volcano locations in latitude and longitude (presented in degrees and minutes rounded to the nearest minute) and summit elevations are taken from the Alaska Volcano Observatory database (WGS 1984 datum) and may differ slightly from previously published compilations. For Russian volcanoes, we adopt the location and elevation information of KVERT and SVERT. These, too, may differ slightly from previous compilations and from the Smithsonian Global Volcanism database. 
Table 1. History of seismic monitoring of Alaskan volcanoes from August 1971 through December 2008.

[History of seismic monitoring compiled by J. Dixon. "First station installed" refers to the date when AVO first received real-time data from the station. This date can be many months following initial fieldwork at the volcano. Alaska Volcano Observatory (AVO) considers the seismic network "complete" following installation and data transmission from a minimum of four seismic stations. Typically, AVO seismologists wait about 6 months or more to understand background rates of seismicity before formally declaring a volcano seismically monitored and adding it to the monitored list. We note here the first mention of the seismic status of each monitored volcano in the AVO weekly update. Regularly issued written information statements began during the Redoubt eruption in 1989-90 and were expanded to include all Cook Inlet volcanoes in April 1991. The Magnitude of Completeness is the lowest magnitude that can confidently be located for activity detected in 2008. For more information on specific seismic network histories, readers are referred to the series of annual seismic summaries prepared by AVO (for example, Dixon and Stihler, 2009]

\begin{tabular}{|c|c|c|}
\hline Volcano & Approximate start date of seismic monitoring & $\begin{array}{l}\text { Magnitude of } \\
\text { completeness }\end{array}$ \\
\hline Wrangell & $\begin{array}{l}\text { First station installed - July } 2000 \\
\text { Network complete - August } 2001 \\
\text { Added to monitored list in weekly update - November } 2001\end{array}$ & 1.0 \\
\hline Spurr & $\begin{array}{l}\text { First station installed - August } 1971 \\
\text { Network complete - August } 1989 \\
\text { Added to monitored list in weekly update - April } 1991\end{array}$ & 0.1 \\
\hline Redoubt & $\begin{array}{l}\text { First station installed - August } 1971 \\
\text { Network complete - August } \mathbf{1 9 8 8} \\
\text { Added to monitored list in weekly update - April } 1991\end{array}$ & 0.2 \\
\hline Iliamna & $\begin{array}{l}\text { First station installed - September } 1987 \\
\text { Network complete (Min } 4 \text { stations) - September } 1994 \\
\text { Added to monitored list in weekly update - April } 1991\end{array}$ & 0.7 \\
\hline Augustine & $\begin{array}{l}\text { First station installed - October } 1976 \\
\text { Network complete - August } \mathbf{1 9 7 8} \\
\text { Added to monitored list in weekly update - April } 1991\end{array}$ & 0.1 \\
\hline Fourpeaked & $\begin{array}{l}\text { First station installed - September } 2006 \\
\text { Network complete (Min } 4 \text { stations) - October } 2006 \\
\text { Added to monitored list in weekly update - October } 2006\end{array}$ & 0.9 \\
\hline Katmai-North (Snowy) & $\begin{array}{l}\text { First station installed - August } 1988 \\
\text { Network complete - October } \mathbf{1 9 9 8} \\
\text { Added to monitored list in weekly update - December } 1998\end{array}$ & 0.9 \\
\hline $\begin{array}{l}\text { Katmai-Central (Griggs, Katmai, } \\
\text { Novarupta, Trident) }\end{array}$ & $\begin{array}{l}\text { First station installed - August } 1988 \\
\text { Network complete (Min } 4 \text { stations) - July } 1991 \\
\text { Added to monitored list in weekly update - November } 1996\end{array}$ & 0.8 \\
\hline Katmai-South (Martin, Mageik) & $\begin{array}{l}\text { First station installed - August } 1988 \\
\text { Network complete - July } 1996 \\
\text { Added to monitored list in weekly update - November } 1996\end{array}$ & 0.4 \\
\hline Ukinrek Maars/ Peulik & $\begin{array}{l}\text { First station installed - March } 2005 \\
\text { Network complete (Min } 4 \text { stations) - March } 2005 \\
\text { Added to monitored list in weekly update - April } 2005\end{array}$ & 1.3 \\
\hline Aniakchak & $\begin{array}{l}\text { First station installed - July } 1997 \\
\text { Network complete - July } 1997 \\
\text { Added to monitored list in weekly update - November } 1997\end{array}$ & 1.3 \\
\hline Veniaminof & $\begin{array}{l}\text { First station installed - February } 2002 \\
\text { Network complete - February } 2002 \\
\text { Added to monitored list in weekly update - September } 2002\end{array}$ & 1.3 \\
\hline Pavlof & $\begin{array}{l}\text { First station installed - July } 1996 \\
\text { Network complete - July } 1996 \\
\text { Added to monitored list in weekly update - November } 1996\end{array}$ & 0.5 \\
\hline
\end{tabular}


Table 1. History of seismic monitoring of Alaskan volcanoes from August 1971 through December 2008.—Continued

[History of seismic monitoring compiled by J. Dixon. "First station installed" refers to the date when AVO first received real-time data from the station. This date can be many months following initial fieldwork at the volcano. Alaska Volcano Observatory (AVO) considers the seismic network "complete" following installation and data transmission from a minimum of four seismic stations. Typically, AVO seismologists wait about 6 months or more to understand background rates of seismicity before formally declaring a volcano seismically monitored and adding it to the monitored list. We note here the first mention of the seismic status of each monitored volcano in the AVO weekly update. Regularly issued written information statements began during the Redoubt eruption in 1989-90 and were expanded to include all Cook Inlet volcanoes in April 1991. The Magnitude of Completeness is the lowest magnitude that can confidently be located for activity detected in 2008. For more information on specific seismic network histories, readers are referred to the series of annual seismic summaries prepared by AVO (for example, Dixon and Stihler, 2009]

\begin{tabular}{|c|c|c|}
\hline Volcano & Approximate start date of seismic monitoring & $\begin{array}{l}\text { Magnitude of } \\
\text { completeness }\end{array}$ \\
\hline Dutton & $\begin{array}{l}\text { First station installed - July } 1988 \\
\text { Network complete - July } \mathbf{1 9 9 6} \\
\text { Added to monitored list in weekly update - November } 1996\end{array}$ & 1.2 \\
\hline Shishaldin (and Isantoski) & $\begin{array}{l}\text { First station installed - July } 1997 \\
\text { Network complete - July } \mathbf{1 9 9 7} \\
\text { Shishaldin added to list in weekly update - November } 1997 \\
\text { Isantoski added to list in weekly update - December } 1998\end{array}$ & 0.9 \\
\hline Westdahl (and Fisher) & $\begin{array}{l}\text { First station installed - August } 1998 \\
\text { Network complete - October } 1998 \\
\text { Added to monitored list in weekly update - December } 1998\end{array}$ & 1.5 \\
\hline Akutan & $\begin{array}{l}\text { First station installed - March } 1996 \\
\text { Network complete - July } 1996 \\
\text { Added to monitored list in weekly update - November } 1996\end{array}$ & 0.3 \\
\hline Makushin & $\begin{array}{l}\text { First station installed - July } 1996 \\
\text { Network complete - July } 1996 \\
\text { Added to monitored list in weekly update - November } 1996\end{array}$ & 0.7 \\
\hline Okmok & $\begin{array}{l}\text { First station installed - January } 2003 \\
\text { Network complete - January } 2003 \\
\text { Added to monitored list in weekly update - January } 2004\end{array}$ & 1.1 \\
\hline Korovin & $\begin{array}{l}\text { First station installed - July } 2004 \\
\text { Network complete - July } 2004 \\
\text { Added to monitored list in weekly update - December } 2005\end{array}$ & 1.3 \\
\hline Great Sitkin & $\begin{array}{l}\text { First station installed - September } 1999 \\
\text { Network complete - September } 1999 \\
\text { Added to monitored list in weekly update - December } 1999\end{array}$ & -0.5 \\
\hline Kanaga & $\begin{array}{l}\text { First station installed - September } 1999 \\
\text { Network complete - September } 1999 \\
\text { Added to monitored list in weekly update - December } 2000\end{array}$ & 1.2 \\
\hline Tanaga & $\begin{array}{l}\text { First station installed - August } 2003 \\
\text { Network complete - August } 2003 \\
\text { Added to monitored list in weekly update - June } 2004\end{array}$ & 1.1 \\
\hline Gareloi & $\begin{array}{l}\text { First station installed - August } 2003 \\
\text { Network complete - September } 2003 \\
\text { Added to monitored list in weekly update - June } 2004\end{array}$ & 1.7 \\
\hline Semisopochnoi (Cerberus) & $\begin{array}{l}\text { First station installed - September } 2005 \\
\text { Network complete - September } 2005 \\
\text { Added to monitored list in weekly update - not yet added }\end{array}$ & 0.8 \\
\hline Little Sitkin & $\begin{array}{l}\text { First station installed - September } 2005 \\
\text { Network complete - September } 2005 \\
\text { Added to monitored list in weekly update - not yet added }\end{array}$ & 0.4 \\
\hline
\end{tabular}


Table 2. Summary of 2008 VOLCANIC ACTIVITY in Alaska, including actual eruptions, possible eruptions, and unusual increases in seismicity or fumarolic activity.

[Location of volcanoes shown in figure 1]

\begin{tabular}{lll}
\hline \multicolumn{1}{c}{ Volcano } & \multicolumn{1}{c}{ Date of activity } & \multicolumn{1}{c}{ Type of activity } \\
\hline Redoubt & Summer (?) - end of 2008 & Increased gas and thermal flux; meltwater and debris discharge down Drift glacier. \\
Aniakchak & March 2008 & Weather-induced signals on seismic stations; not volcanic. \\
Veniaminof & February 11-29, 2008 & Sporadic seismicity, minor phreatic ash emissions and vapor plumes. \\
Shishaldin & Intermittently throughout 2008 & Minor phreatic ash (?) emission and vigorous vapor plumes. \\
Okmok & July 12-August 19, 2008 & Significant phreatomagmatic eruption. \\
Cleveland & Intermittently throughout 2008 & Explosions and small ash clouds, avalanches of hot debris into the sea. \\
Kasatochi & August 7-8, 2008 & Significant explosive eruption following intense seismic swarm. \\
\hline
\end{tabular}

Table 3. Alaskan volcanoes with Color Code changes in 2008.

[Description of Level of Concern Color Codes is shown in appendix 1. Local times are only shown where color code changes were short-lived during rapidly evolving events. Volcanoes that do not have a real-time seismic network are not assigned a color code GREEN because without seismic data, Alaska Volcano Observatory has no definitive information that the level of activity at the volcano is at background. For these volcanoes, AVO uses the designation

UNASSIGNED]

\begin{tabular}{|l|l|}
\hline \multicolumn{1}{|c}{ Color Code } & Date of change \\
\hline \multicolumn{2}{|c|}{ REDOUBT } \\
\hline GREEN & January 1-November 5 \\
\hline YELLOW & November 5-December 31 \\
\hline \multicolumn{2}{|c|}{ VENIMINOF } \\
\hline GREEN & January 1-February 22 \\
\hline YELLOW & February 22-May 3 \\
\hline GREEN & May 3-December 31 \\
\hline \multicolumn{1}{|c|}{ OKMOK } \\
\hline GREEN & January 1-July 12 \\
\hline RED & July 12-July 16 \\
\hline ORANGE & July 16-July 19 \\
\hline RED & July 19-July 20 \\
\hline ORANGE & July 20-July 25 \\
\hline RED & July 25-July 26 \\
\hline ORANGE & July 26-July 28 \\
\hline RED & July 28-July 30 \\
\hline ORANGE & July 30-August 2 \\
\hline RED & August 2 0442-1535 \\
\hline ORANGE & August 2 1535-August 27 \\
\hline YELLOW & August 27-November 19 \\
\hline GREEN & November 19-December 31 \\
\hline & \\
\hline
\end{tabular}

\begin{tabular}{|l|l|}
\multicolumn{1}{c}{ Color Code } & \multicolumn{1}{c|}{ CLEVELAND } \\
\hline \multicolumn{2}{|c|}{ Date of change } \\
\hline YELLOW & January 1-February 8 \\
\hline ORANGE & February 8-February 12 \\
\hline YELLOW & February 12-July 21 \\
\hline ORANGE & July 21-August 6 \\
\hline YELLOW & August 6-August 11 \\
\hline ORANGE & August 11-August 25 \\
\hline YELLOW & August 25-October 9 \\
\hline UNASSIGNED & October 9-December 24 \\
\hline YELLOW & December 24-December 31 \\
\hline \multicolumn{2}{|c|}{ KASATOCHI } \\
\hline UNASSIGNED & January 1-August 6 \\
\hline YELLOW & August 6-August 7 1357 \\
\hline ORANGE & August 7 1357-August 7 1526 \\
\hline RED & August 7 1526-August 9 2204 \\
\hline ORANGE & August 9 2204- September 4 \\
\hline YELLOW & September 4-October 30 \\
\hline UNASSIGNED & October 30-December 31 \\
\hline
\end{tabular}


Table 4a. Compilation by year of volcanoes included in an Alaska Volcano Observatory Annual Summary, 1992-2008.

[Volcanoes are presented in geographical order from northeast to southwest along the Wrangell-Aleutian volcanic arc and north to south along Kamchatka and the Kurile Islands. Prior to 1995, Alaska Volcano Observatory did not report on Russian volcanoes]

\begin{tabular}{lc}
\hline \multicolumn{1}{c}{ Volcanoes mentioned } \\
\hline \multicolumn{1}{c}{ Alaskan } & \multicolumn{1}{c}{ Russian } \\
\hline Spurr/Crater Peak & \\
Iliamna \\
Redoubt \\
Mageik (Katmai Group) \\
Westdahl \\
Akutan \\
Bogoslof \\
Seguam \\
\hline \\
\end{tabular}

Churchill

Sanford

Spurr/Crater Peak

Veniaminof

Shishaldin

Makushin

Seguam

Kliuchef (Atka)

Kanaga

1994

Sanford

Iliamna

Katmai Group (Martin,

Mageik, Trident)

Veniaminof

Kupreanof

Shishaldin

Makushin

Cleveland

Kanaga

\begin{tabular}{lc}
\hline & 1995 \\
\hline Katmai Group (Martin) & Bezymianny \\
Veniaminof & Karymsky \\
Shishaldin & \\
Makushin & \\
Kliuchef (Atka) & \\
Kanaga & \\
\hline & 1996
\end{tabular}

Wrangell
Iliamna
Katmai Group (Martin,
Mageik, Trident, Mount
Katmai)
Pavlof

Shishaldin

Westdahl

Klyuchevskoy

Bezymianny

Karymsky

Avachinsky

Mutnovsky

Alaid (Kurile Islands)

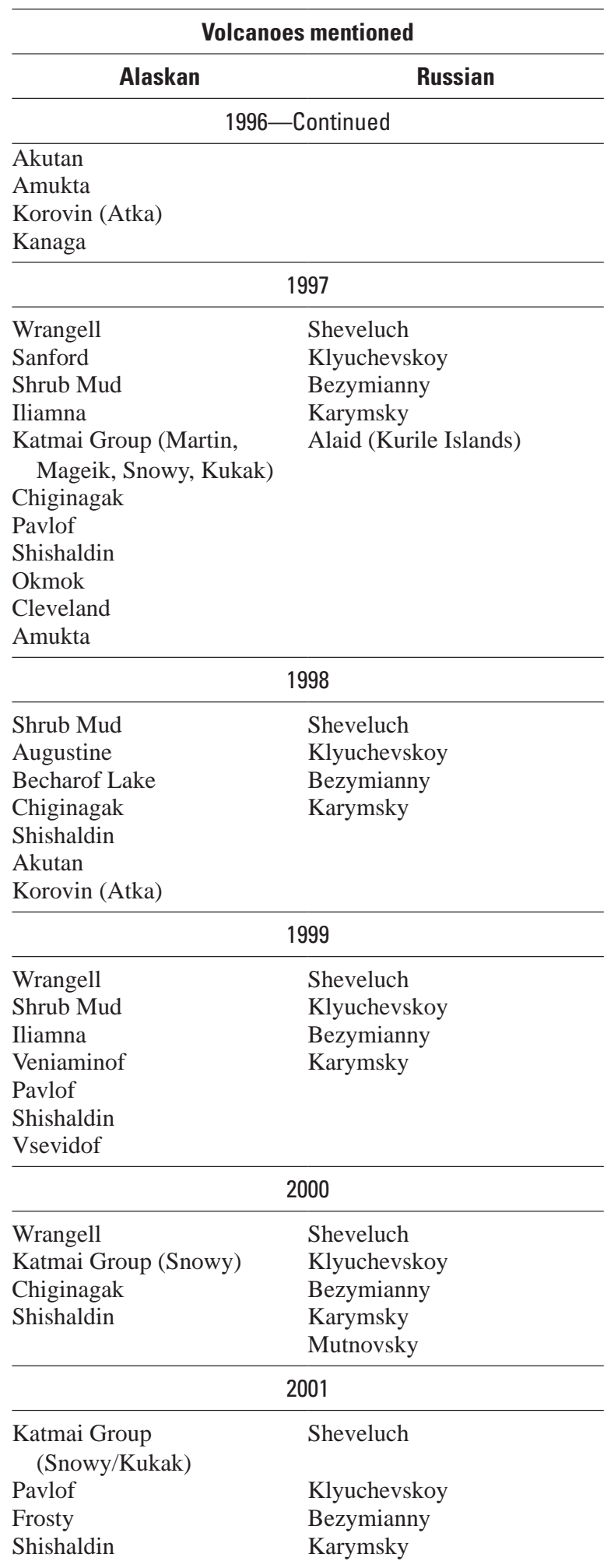


Table 4a. Compilation by year of volcanoes included in an Alaska Volcano Observatory Annual Summary, 1992-2008.—Continued

[Volcanoes are presented in geographical order from northeast to southwest along the Wrangell-Aleutian volcanic arc and north to south along Kamchatka and the Kurile Islands. Prior to 1995, Alaska Volcano Observatory did not report on Russian volcanoes]

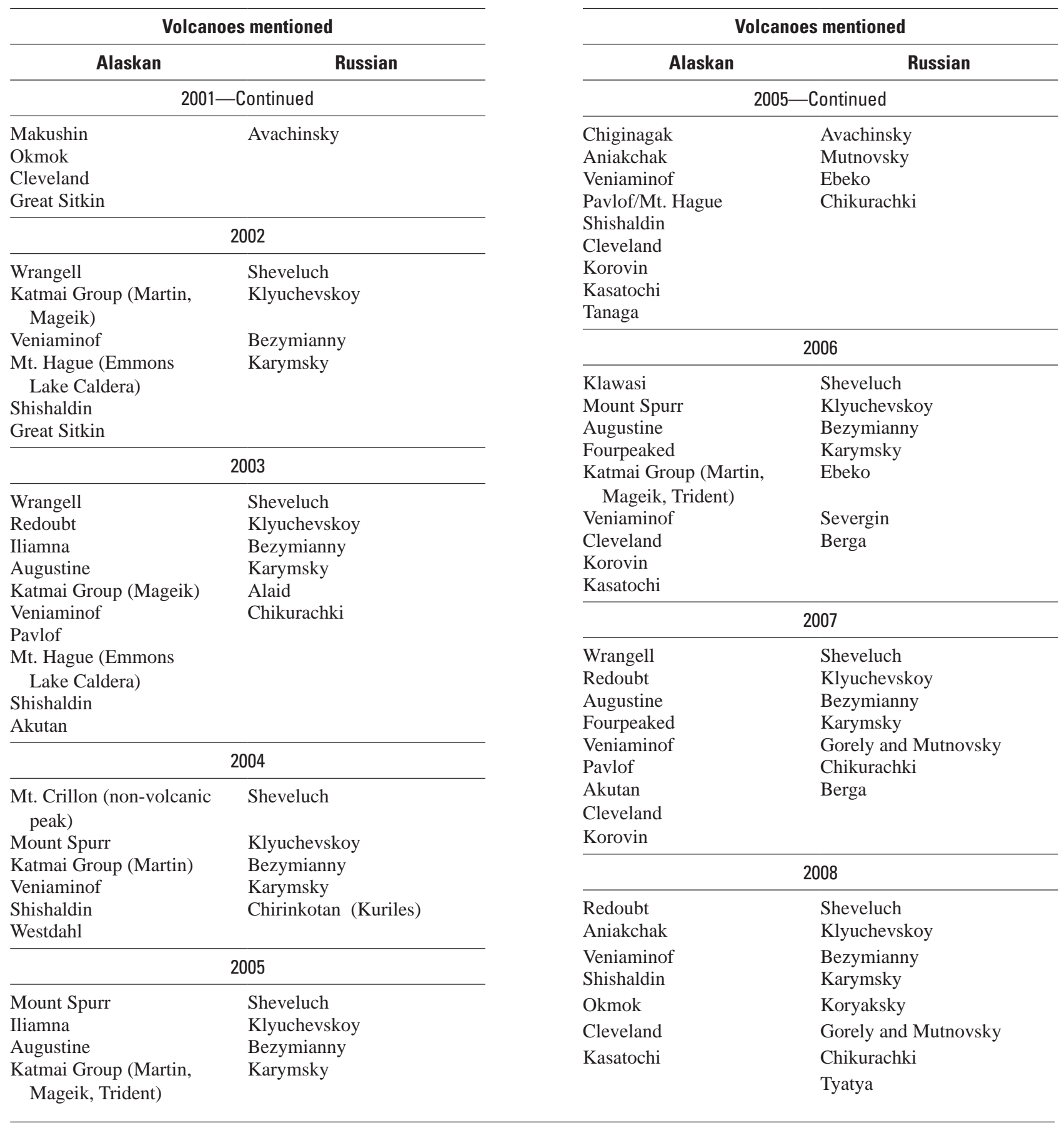


Table 4b. Compilation by volcano for particular years included in an Alaska Volcano Observatory Annual Summary, 1992-2008.

[Suspect Volcanic Activity (SVA) is defined as a report of eruption or possible eruption that is normal fumarolic activity or non-volcanic phenomena, such as weather related. PIREP, pilot weather report]

\begin{tabular}{|c|c|c|}
\hline Volcano & Year mentioned & Type of activity \\
\hline \multicolumn{3}{|c|}{ Alaska (east to west) } \\
\hline Churchill & 1993 & SVA, anomalous seismicity \\
\hline Wrangell & $\begin{array}{l}1996 \\
1997 \\
1999 \\
2000 \\
2002 \\
2003 \\
2007\end{array}$ & $\begin{array}{l}\text { SVA, steam plume } \\
\text { SVA, steam plume } \\
\text { SVA, steaming and phreatic ash emission } \\
\text { SVA, steam plumes } \\
\text { SVA, suspicious clouds, redistributed ash } \\
\text { SVA, anomalous clouds } \\
\text { Triggered seismicity; steam plumes and redistributed ash }\end{array}$ \\
\hline Sanford & $\begin{array}{l}1993 \\
1994 \\
1997\end{array}$ & $\begin{array}{l}\text { SVA, reported steam plume likely from avalanche } \\
\text { SVA, reported steam plume likely from avalanche } \\
\text { SVA, large steam cloud from SW face }\end{array}$ \\
\hline Shrub Mud & $\begin{array}{l}1997 \\
1998 \\
1999\end{array}$ & $\begin{array}{l}\text { Eruption; energetic ejection of saline mud and } \mathrm{CO}_{2} \\
\text { Eruption continues; saline mud and } \mathrm{CO}_{2} \text { ejected } \\
\text { Eruption continues; saline mud and } \mathrm{CO}_{2} \text { emission }\end{array}$ \\
\hline Klawasi Mud & 2006 & Possible new mud vent \\
\hline Spurr & $\begin{array}{l}1992 \\
1993 \\
2004 \\
2005 \\
2006\end{array}$ & $\begin{array}{l}\text { Subplinian eruptions; ash, pyroclastic flows, lahars } \\
\text { SVA, glacial outburst produces seismicity } \\
\text { Heat flux to summit; lahars; cauldron develops } \\
\text { Continued heat to summit; cauldron evolves } \\
\text { Continued heat to summit; cauldron evolves }\end{array}$ \\
\hline Redoubt & $\begin{array}{l}1992 \\
2003 \\
2007 \\
2008\end{array}$ & $\begin{array}{l}\text { SVA, steam plume from still-cooling dome } \\
\text { SVA, anomalous weather cloud } \\
\text { Possible first signs of precursory activity leading to eruption in } 2009 \\
\text { Precursory activity leading to } 2009 \text { eruption }\end{array}$ \\
\hline Iliamna & $\begin{array}{l}1992 \\
1994 \\
1996 \\
1997 \\
1999 \\
2003 \\
2005\end{array}$ & $\begin{array}{l}\text { SVA, PIREP of large steam plume, media frenzy } \\
\text { SVA, vigorous steam plume, avalanche } \\
\text { Intense seismicity related to magmatic intrusion } \\
\text { SVA; anomalous seismic swarm; avalanche } \\
\text { SVA, avalanche } \\
\text { SVA, avalanche } \\
\text { SVA, rock avalanche }\end{array}$ \\
\hline Augustine & $\begin{array}{l}1998 \\
2005 \\
2006 \\
2007\end{array}$ & $\begin{array}{l}1986 \text { dome spine partially collapses, generates mudflow } \\
\text { Precursory activity prior to eruption in early } 2006 \\
\text { Explosive and effusive eruption } \\
\text { Strong seismic events; reports of steam plumes }\end{array}$ \\
\hline Fourpeaked & $\begin{array}{ll}2006 \\
2007\end{array}$ & $\begin{array}{l}\text { Phreatic eruption } \\
\text { Ongoing fumarolic emissions }\end{array}$ \\
\hline
\end{tabular}


Table 4b. Compilation by volcano for particular years included in an Alaska Volcano Observatory Annual Summary, 1992-2008.-Continued

[Suspect Volcanic Activity (SVA) is defined as a report of eruption or possible eruption that is normal fumarolic activity or non-volcanic phenomena, such as weather related. PIREP, pilot weather report]

\begin{tabular}{|c|c|c|}
\hline Volcano & Year mentioned & Type of activity \\
\hline \multicolumn{3}{|c|}{ Alaska (east to west)—Continued } \\
\hline \multicolumn{3}{|l|}{ Katmai Group } \\
\hline Mageik & 1992 & SVA, anomalous cloud \\
\hline Martin/Mageik/Trident & 1994 & SVA, plume-like cloud \\
\hline Martin & 1995 & SVA, large steam plume \\
\hline Martin/Mageik/Trident/Mount Katmai & 1996 & SVA, anomalous seismicity \\
\hline Martin/Mageik/Snowy/Kukak & 1997 & SVA, PIREPS of ash and steam plumes \\
\hline Snowy & 2000 & SVA, steaming hole in glacier \\
\hline Snowy/Kukak & 2001 & SVA, steaming hole in glacier \\
\hline Martin/Mageik & 2002 & SVA, steam plume \\
\hline Mageik & 2003 & SVA, steaming, large cloud of re-suspended ash \\
\hline Martin & 2004 & SVA, large steam plume \\
\hline Martin & 2006 & Earthquake swarm \\
\hline Martin/Mageik/Trident & 2005 & SVA, steam cloud, re-suspended ash, new crater? \\
\hline Becharof Lake & 1998 & SVA, intense seismic swarm and inflationary episode \\
\hline \multirow[t]{4}{*}{ Chiginagak } & 1997 & Minor eruptive activity, new fumarole field \\
\hline & 1998 & SVA, continuation of increased fumarolic activity \\
\hline & 2000 & SVA, steam emissions from fumarole field \\
\hline & 2005 & Heat to summit; acidic flood; cauldron develops \\
\hline \multirow[t]{2}{*}{ Aniakchak } & 2005 & SVA, anomalous seismicity, thermal anomaly \\
\hline & 2008 & Weather related noise on seismic stations \\
\hline \multirow[t]{11}{*}{ Veniaminof } & 1993 & Low-level eruption and lava flows \\
\hline & 1994 & Strombolian eruption and lava flows \\
\hline & 1995 & Strombolian eruptions \\
\hline & 1999 & SVA, extreme discharge and turbid river \\
\hline & 2002 & Low-level phreatic eruptions \\
\hline & 2003 & Low-level phreatic eruptions \\
\hline & 2004 & Weak phreatic and Strombolian eruption \\
\hline & 2005 & Intermittent phreatic and Strombolian eruption \\
\hline & 2006 & Intermittent phreatic and Strombolian eruption \\
\hline & 2007 & Weak phreatic emissions and vapor plumes \\
\hline & 2008 & Weak phreatic emissions and vapor plumes \\
\hline Kupreanof & 1994 & SVA, PIREP of unusual steam plume \\
\hline \multirow[t]{6}{*}{ Pavlof } & 1996 & Strombolian eruption \\
\hline & 1997 & Strombolian eruption concludes \\
\hline & 1999 & SVA, summit snow melt, ash dustings, steam plumes \\
\hline & 2001 & SVA, steaming, possible ash, sulfur smell \\
\hline & 2005 & SVA, mis-located steam plume \\
\hline & 2007 & Strombolian eruption \\
\hline \multirow[t]{3}{*}{ Hague (Emmons Lake Caldera) } & 2002 & SVA, increase in fumarolic activity in summit crater \\
\hline & 2003 & SVA, crater lake drains, refills, drains \\
\hline & 2005 & SVA, steam plume \\
\hline Frosty & 2001 & SVA, rock fall avalanches \\
\hline
\end{tabular}


Table 4b. Compilation by volcano for particular years included in an Alaska Volcano Observatory Annual Summary, 1992-2008.-Continued

[Suspect Volcanic Activity (SVA) is defined as a report of eruption or possible eruption that is normal fumarolic activity or non-volcanic phenomena, such as weather related. PIREP, pilot weather report]

\begin{tabular}{|c|c|c|}
\hline Volcano & Year mentioned & Type of activity \\
\hline \multicolumn{3}{|c|}{ Alaska (east to west)-Continued } \\
\hline \multirow{14}{*}{ Shishaldin } & 1993 & Minor phreatic \\
\hline & 1994 & SVA, PIREP of minor steam/ash \\
\hline & 1995 & Minor eruptive activity, steam/ash \\
\hline & 1996 & Eruption; steam/ash and thermal anomaly \\
\hline & 1997 & Minor eruptive activity, steam/ash \\
\hline & 1998 & Minor eruptive activity, steam/ash \\
\hline & 1999 & Strombolian eruption \\
\hline & 2000 & Minor eruptive activity, steam/ash \\
\hline & 2001 & Minor unrest, seismicity increase, steam clouds \\
\hline & 2002 & SVA, shallow seismicity; PIREP of possible eruption \\
\hline & 2003 & SVA, steam plumes \\
\hline & 2004 & Small steam and ash plumes \\
\hline & 2005 & SVA, increased seismicity, steam plumes prompt PIREPS \\
\hline & 2008 & Minor phreatic ash emission and vigorous vapor plumes \\
\hline \multirow[t]{3}{*}{ Westdahl } & 1992 & Fissure eruption, lava fountains, ash clouds, lava flow \\
\hline & 1996 & SVA, suspicious weather cloud on satellite image \\
\hline & 2004 & SVA, seismic swarm \\
\hline \multirow[t]{5}{*}{ Akutan } & 1992 & SVA, steam/ash emissions \\
\hline & 1996 & Intensive seismicity, ground cracking \\
\hline & 1998 & SVA, tremor-like seismicity \\
\hline & 2003 & SVA, anomalous steam plume \\
\hline & 2007 & Triggered seismicity; inflation; anomalous steaming on lower east flank \\
\hline \multirow[t]{4}{*}{ Makushin } & 1993 & Minor phreatic \\
\hline & 1994 & SVA, PIREP of minor steam/ash \\
\hline & 1995 & SVA, steam plume \\
\hline & 2001 & SVA, increase in seismicity \\
\hline Bogoslof & 1992 & Dome extrusion, ash and steam emissions \\
\hline \multirow[t]{3}{*}{ Okmok } & 1997 & Strombolian eruption \\
\hline & 2001 & SVA, seismic swarm \\
\hline & 2008 & Major phreatomagmatic eruption \\
\hline Vsevidof & 1999 & SVA, sighting of ash after regional earthquake \\
\hline \multirow[t]{7}{*}{ Cleveland } & 1994 & SVA, possible steam/ash emission \\
\hline & 1997 & Minor eruption, steam/ash \\
\hline & 2001 & Eruption; gas/ash, lava/debris flows \\
\hline & 2005 & Intermittent explosions \\
\hline & 2006 & Intermittent explosions \\
\hline & 2007 & Intermittent explosions, small ash clouds \\
\hline & 2008 & Intermittent explosions, small ash clouds \\
\hline \multirow[t]{2}{*}{ Amukta } & 1996 & Small eruption; ash emission \\
\hline & 1997 & SVA, PIREP of small ash eruption \\
\hline \multirow[t]{2}{*}{ Seguam/Pyre Peak } & 1992 & Minor eruptive activity, steam/ash emissions \\
\hline & 1993 & Fissure eruption produces lava flow and ash cloud \\
\hline \multirow[t]{2}{*}{ Kliuchef (Atka) } & 1993 & SVA, audible rumbling, strong sulfur odor \\
\hline & 1995 & SVA, large steam plume, strong sulfur odor \\
\hline
\end{tabular}


Table 4b. Compilation by volcano for particular years included in an Alaska Volcano Observatory Annual Summary, 1992-2008.-Continued

[Suspect Volcanic Activity (SVA) is defined as a report of eruption or possible eruption that is normal fumarolic activity or non-volcanic phenomena, such as weather related. PIREP, pilot weather report]

\begin{tabular}{|c|c|c|}
\hline Volcano & Year mentioned & Type of activity \\
\hline \multicolumn{3}{|c|}{ Alaska (east to west)—Continued } \\
\hline Korovin (Atka) & $\begin{array}{l}1996 \\
1998 \\
2005 \\
2006 \\
2007\end{array}$ & $\begin{array}{l}\text { SVA, PIREP of ash cloud, suspicious cloud on satellite image } \\
\text { Eruption; explosions and ash fall } \\
\text { Minor eruption, steam and ash } \\
\text { Seismic swarms, uplift, increased fumarolic activity } \\
\text { Seismic swarm; fumarolic activity; inflation rate decreases }\end{array}$ \\
\hline Kasatochi & $\begin{array}{l}2005 \\
2006 \\
2008\end{array}$ & $\begin{array}{l}\text { SVA, unusual bubbling; floating scum on crater lake } \\
\text { Continued bubbling in intracaldera lake } \\
\text { Major explosive eruption }\end{array}$ \\
\hline Great Sitkin & $\begin{array}{l}2001 \\
2002\end{array}$ & $\begin{array}{l}\text { SVA, anomalous seismicity } \\
\text { SVA, seismic swarm, tremor }\end{array}$ \\
\hline Kanaga & $\begin{array}{l}1993 \\
1994 \\
1995 \\
1996\end{array}$ & $\begin{array}{l}\text { SVA, increased steaming } \\
\text { Eruption; steam/ash and lava flow } \\
\text { Minor eruptive activity, steam/ash and lava } \\
\text { Possible eruption and ash emission }\end{array}$ \\
\hline Tanaga & 2005 & SVA, anomalous seismicity, including a period of tremor \\
\hline \multicolumn{3}{|c|}{ Kamchatka and northern Kurile Islands (north to south) } \\
\hline Sheveluch & $\begin{array}{l}1997 \\
1998 \\
1999 \\
2000 \\
2001 \\
2002 \\
2003 \\
2004 \\
2005 \\
2006 \\
2007 \\
2008\end{array}$ & $\begin{array}{l}\text { Dome extrusion } \\
\text { Lava dome growth } \\
\text { Lava dome growth and collapse, ash } \\
\text { Lava dome growth, ash } \\
\text { Lava dome growth and collapse, ash } \\
\text { Lava dome growth, ash, pyroclastic flows } \\
\text { Lava dome growth, ash, pyroclastic flows, lahar } \\
\text { Lava dome growth, pyroclastic flows, lahars, ash } \\
\text { Lava dome growth, dome collapse, pyroclastic flows, ash } \\
\text { Lava dome growth, dome collapse, explosions } \\
\text { Lava dome growth, dome collapse, explosions, ash plumes, avalanches } \\
\text { Lava dome growth, dome collapse, explosions }\end{array}$ \\
\hline Klyuchevskoy & $\begin{array}{l}1996 \\
1997 \\
1998 \\
1999 \\
2000 \\
2001 \\
2002 \\
2003 \\
2004 \\
2005 \\
2006 \\
2007 \\
2008\end{array}$ & $\begin{array}{l}\text { Gas/ash eruption } \\
\text { Gas/ash eruption } \\
\text { Gas/ash eruption } \\
\text { Gas/ash eruption } \\
\text { Vulcanian explosions } \\
\text { Fumarolic plume } \\
\text { Elevated seismicity, gas-rich explosion } \\
\text { Elevated seismicity, ash explosion, Strombolian activity } \\
\text { Elevated seismicity } \\
\text { Strombolian eruption, lava flows, lahars } \\
\text { Increased seismicity, thermal anomaly, no eruption } \\
\text { Strombolian explosions, lava flows } \\
\text { Strombolian lava fountaining, lava flows, lahars, phreatic explosions }\end{array}$ \\
\hline
\end{tabular}


Table 4b. Compilation by volcano for particular years included in an Alaska Volcano Observatory Annual Summary, 1992-2008.-Continued

[Suspect Volcanic Activity (SVA) is defined as a report of eruption or possible eruption that is normal fumarolic activity or non-volcanic phenomena, such as weather related. PIREP, pilot weather report]

\begin{tabular}{|c|c|c|}
\hline Volcano & Year mentioned & Type of activity \\
\hline \multicolumn{3}{|c|}{ Kamchatka and northern Kurile Islands (north to south)_-Continued } \\
\hline \multirow[t]{13}{*}{ Bezymianny } & 1995 & Explosive eruption \\
\hline & 1996 & Lava extrusion \\
\hline & 1997 & Dome collapse and explosive eruption \\
\hline & 1998 & Degassing and spalling of new dome \\
\hline & 1999 & Degassing and spalling of new dome, ash \\
\hline & 2000 & Dome growth, explosive eruption \\
\hline & 2001 & Accelerated dome growth, pyroclastic flows \\
\hline & 2002 & Accelerated dome growth, explosions, pyroclastic flows \\
\hline & 2003 & Dome growth and explosive collapse \\
\hline & 2004 & Minor explosive eruptions, gas and steam emissions \\
\hline & 2005 & Dome growth continues, two explosive episodes \\
\hline & 2006 & Dome growth continues, two explosive episodes \\
\hline & 2007 & Intermittent lava dome growth and explosions \\
\hline \multirow[t]{14}{*}{ Karymsky } & 1995 & Increased seismicity \\
\hline & 1996 & Explosive eruption \\
\hline & 1997 & Low level Strombolian eruptions \\
\hline & 1998 & Low level Strombolian eruptions \\
\hline & 1999 & Low level Vulcanian and Strombolian eruptions \\
\hline & 2000 & Low level Vulcanian and Strombolian eruptions \\
\hline & 2001 & Low level Vulcanian and Strombolian eruptions \\
\hline & 2002 & Low level Vulcanian and Strombolian eruptions, explosions, avalanches \\
\hline & 2003 & Vulcanian and Strombolian eruptions intensify \\
\hline & 2004 & Low level Vulcanian and Strombolian eruptions \\
\hline & 2005 & Low level Vulcanian and Strombolian eruptions, explosions, lava, ash fall \\
\hline & 2006 & Low level Vulcanian and Strombolian eruptions \\
\hline & 2007 & Vulcanian and Strombolian eruption continues intermittently \\
\hline & 2008 & Low level Vulcanian and Strombolian activity \\
\hline Koryaksky & 2008 & Phreatic explosions and ash emission \\
\hline \multirow[t]{3}{*}{ Avachinsky } & 1996 & Increased seismicity \\
\hline & 2001 & Increased seismicity, phreatic explosion \\
\hline & 2005 & Increased seismicity, thermal anomalies \\
\hline \multirow[t]{5}{*}{ Mutnovsky } & 1996 & Fumarolic plume \\
\hline & 2000 & Gas and steam explosion \\
\hline & 2005 & Increased fumarolic activity \\
\hline & 2007 & Increased seismicity - source uncertain; fumarolic activity at Gorely \\
\hline & 2008 & Increased seismicity - source uncertain; fumarolic activity at Gorely \\
\hline \multirow[t]{2}{*}{ Alaid (Kurile Islands) } & 1996 & Ash plume \\
\hline & 1997 & SVA \\
\hline \multirow[t]{2}{*}{ Ebeko } & 2005 & Increased fumarolic activity and phreatic eruptions \\
\hline & 2006 & Increased fumarolic activity \\
\hline \multirow[t]{4}{*}{ Chikurachki } & 2003 & Strombolian and Vulcanian eruption, ash fall \\
\hline & 2005 & Brief explosion produces ash and ash fall \\
\hline & 2007 & Brief explosion produces ash cloud and ash fall \\
\hline & 2008 & Explosions and limited ash clouds \\
\hline Severgin & 2006 & Phreatic or fumarolic activity \\
\hline Chirinkotan & 2004 & Brief, low-level steam, gas, and ash emission \\
\hline \multirow[t]{2}{*}{ Berga } & 2006 & Phreatic or fumarolic activity \\
\hline & 2007 & Possible eruption or gas outburst \\
\hline Tyatya & 2008 & Possible increase in fumarolic activity \\
\hline
\end{tabular}


Table 4c. Citations for Alaska Volcano Observatory Annual Summary reports, 1992-2008.

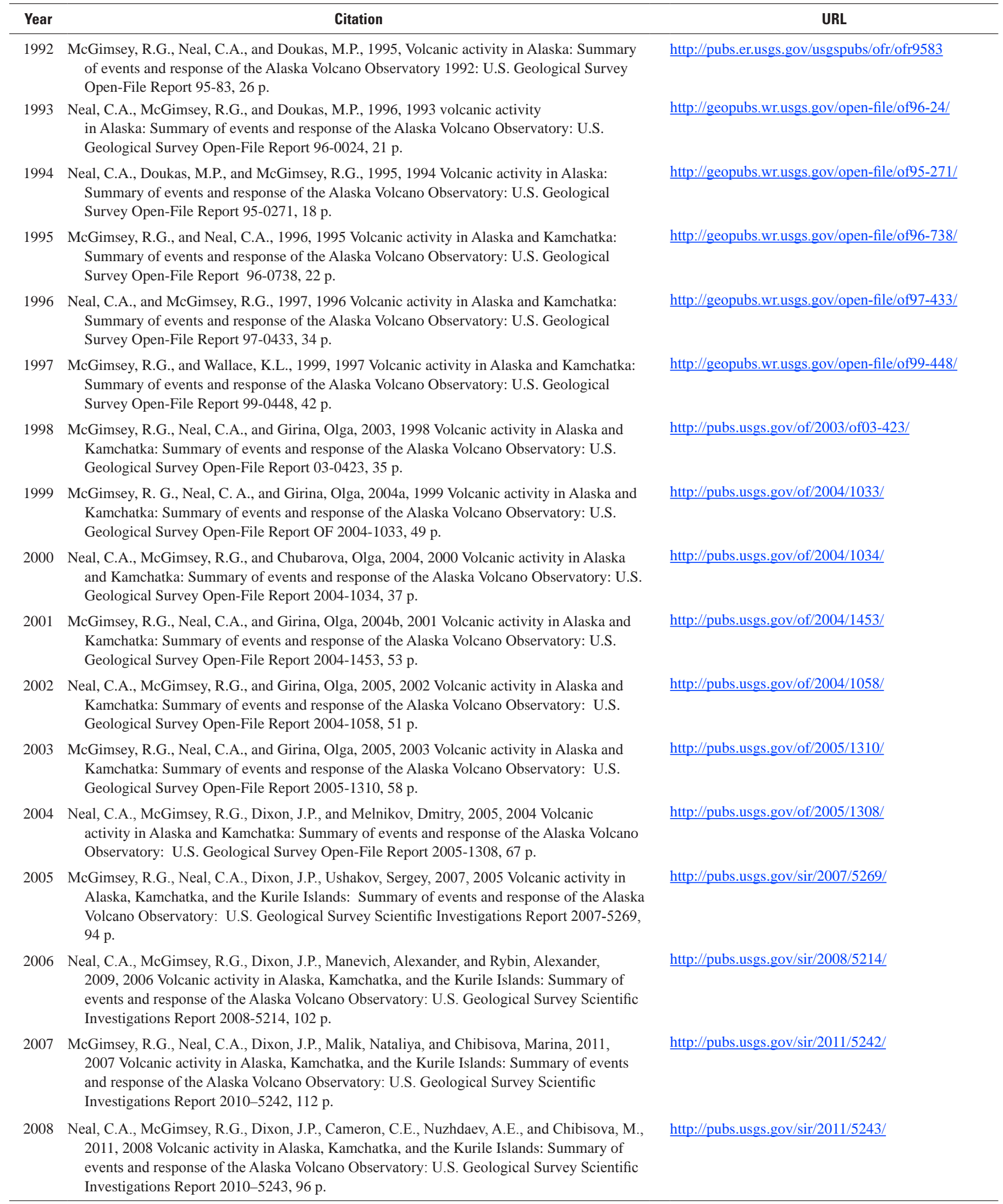




\section{Increasing monitoring, increasing information, more to report}

As AVO has expanded instrumental monitoring (fig. 2) and made use of the increasing number of high resolution satellite platforms, the threshold for detection of volcanic unrest in Alaska has lowered considerably. In addition, increasing air and marine-vessel traffic in the Aleutians along with improved Internet and other telecommunications infrastructure in remote Alaska, along with the highly visible web presence of AVO may all contribute to the increased number of reports of volcanic activity that we receive, evaluate, and log. The focus of this report is on volcanic activity that represents a significant departure from 'background', a somewhat loosely defined state of quiet at a given volcano. For a more quantitative picture of the level of volcanic unrest, readers are referred to the catalog of seismicity at Alaskan volcanoes, also produced on an annual basis (for example, Dixon and Stihler, 2009).

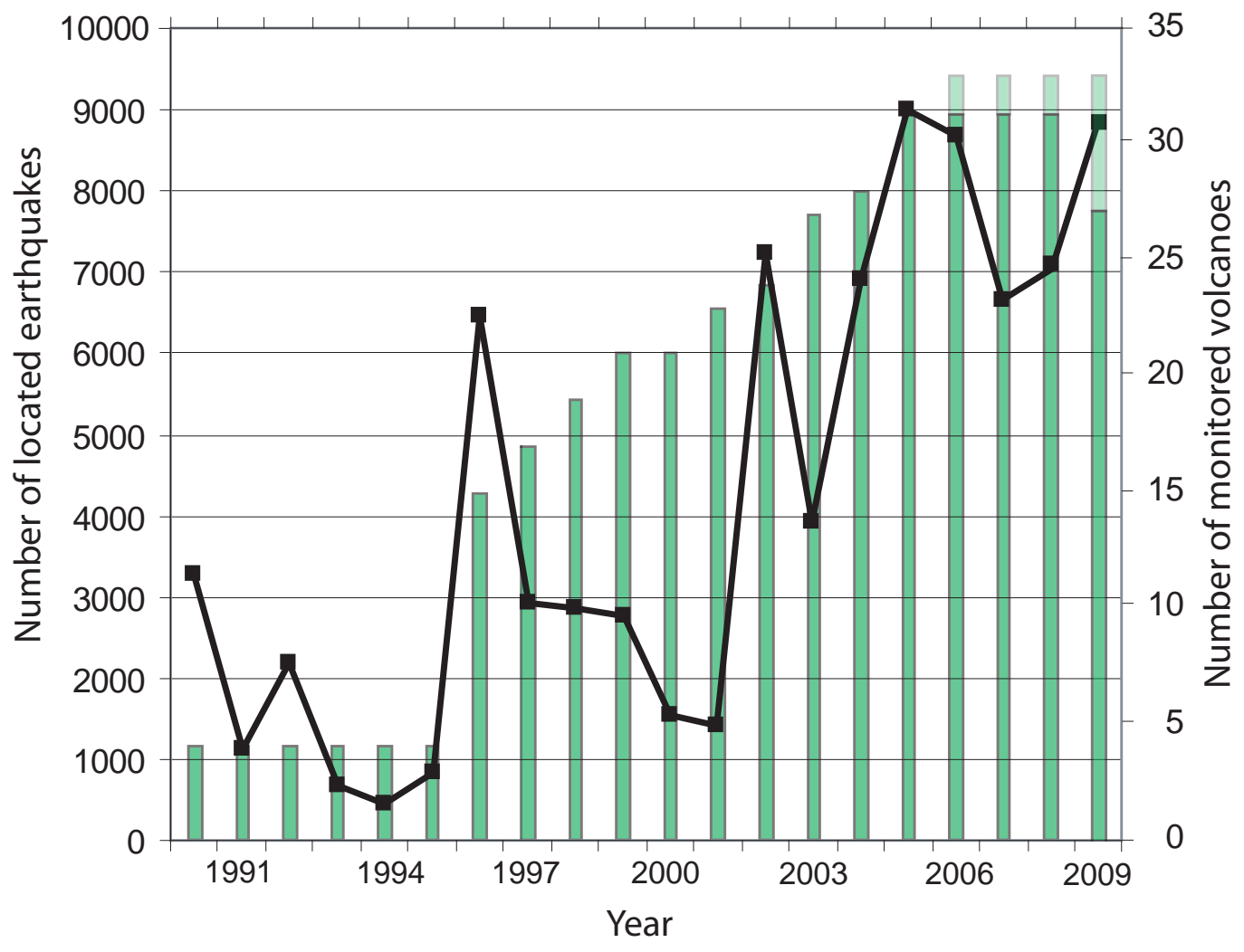

Figure 2. Number of earthquakes located per year in the AVO annual catalogs of seismicity (black line) and number of seismically monitored volcanoes per year (green bars). The lighter green bars represent volcanoes with installed seismic networks but not included on the formal list of monitored volcanoes. 


\section{What is an "eruption"?}

The specific use of the term 'eruption' varies from scientist to scientist and there is no universally agreed-upon definition. Here, we adopt the usage of the Smithsonian Institution's Global Volcanism Program, which defines eruptions as, “...events that involve explosive ejections of fragmental material, the effusion of liquid lava, or both. This fragmental material may be old as well as new; the explosive interaction of volcanically generated heat and near-surface water can cause dramatic eruptions without any fresh volcanic material reaching the surface" (http://www.volcano.si.edu/faq/index.cfm?faq=02). The elements of this definition that we wish to emphasize are the verbs 'eject' and 'effuse' which refer to dynamic surface processes that pose some level of hazard. The presence or absence of often ambiguous 'juvenile material' or fresh magma is not relevant to this use of the term eruption, particularly when communicating a potential hazard that makes no distinction between juvenile and non-juvenile eruption products. This definition would not, however, include passive volcanic degassing or hydrothermal-fluid discharge.

\section{What is an "historically active volcano"?}

AVO defines an "active" volcano as a volcanic center that has had an eruption (see above) or period of intense deformation, seismic or fumarolic activity that is inferred to reflect the presence of magma at shallow levels within the volcano. The "historical" period in Alaska is now considered to be post- about 1700 when written records of volcanic activity began. Based on a rigorous re-analysis of all accounts of volcanic activity in Alaska from many sources, Cameron and others (2008) conclude that 52 Alaskan volcanoes fit these criteria. We recognize that this is a big jump from the often cited 41 of Miller and others (1998), and a change from previously published map compilations. As geologic understanding of Alaska's volcanoes improves through additional fieldwork and modern radiometric-dating techniques, our list of "active" volcanoes will continue to evolve. 


\title{
Volcanic Activity in Alaska, Northeast to Southwest along Aleutian Arc
}

\author{
Redoubt Volcano \\ CAVW\# 1103-03- \\ $60^{\circ} 29^{\prime} \mathrm{N} 152^{\circ} 45^{\prime} \mathrm{W}$ \\ $3,108 \mathrm{~m}(10,197 \mathrm{ft})$ \\ Cook Inlet \\ INCREASED GAS AND THERMAL FLUX \\ From summit crater; meltwater and debris discharge down Drift glacier.
}

2008 saw the beginning of volcanic unrest at Redoubt Volcano which culminated in a magmatic eruption in the spring of 2009 (Bull, 2009). Changes were first noted in the summer of 2008 when AVO geologists working in the vicinity of the volcano detected a distinct hydrogen sulfide gas odor ${ }^{1}$ and a prominent fumarolic pit through the ice and on top of the previously ice-covered 1990 lava dome (fig. 3). In mid-September, a pilot flying downwind of Redoubt Volcano and workers at the Drift River Oil Terminal facility $22 \mathrm{mi}$ (35 km) downstream of the volcano (fig. 4) also reported a strong hydrogen-sulfide odor. In late September, tremor-like signals were detected on the AVO seismic network at Redoubt, and residents of a cabin near Wadell Lake $15 \mathrm{mi}(25 \mathrm{~km})$ northeast of the volcano reported loud noises ("booms") coming from the direction of the volcano.

In response to these reports, AVO sent an observation flight to Redoubt on September 27. AVO staff onboard reported several new fractures and circular openings in the upper Drift glacier as well as increased steaming from fumaroles atop the mid-1960s and 1990 lava domes and vent areas. Most notably, a collapse pit, about 20-30 m (60-100 ft) across, had formed through the Drift glacier at an elevation of about 1,700 m (5,600 ft); observers suspected but could not confirm flowing water in the pit. [It was later determined that this feature had formed near the top of a near-vertical 100-m (330 ft) wall of bedrock where water cascaded onto a bench; the hole in the overlying glacial ice was probably produced by a combination of warm water spray and mechanical disruption.] A distinct hydrogen-sulfide odor also was noted during the flight, although onboard COSPEC (correlation spectrometer) instrumentation measured no sulfur dioxide. AVO’s seismic network at Redoubt had recorded a small

\footnotetext{
${ }^{1}$ AVO seismologists had noted an unusual seismic swarm at Redoubt in February 2008 but attributed the activity to glacial processes. Several orbits of Redoubt during an observation and gas measurement flight in March 2008 indicated no unusual surface activity or evidence of magmatic degassing (M. Doukas, USGS, oral commun., 2010). Recent reanalysis of high resolution thermal satellite data indicates that anomalous melting may have begun at Redoubt as early as 2007 (R.L. Wessels, USGS, oral commun., 2009); AVO also received two reports of steaming at Redoubt in 2007 (McGimsey and others, 2011).
}

number of rockfalls, other surface ice events, and infrasound signals in the late summer and early autumn, but all were thought to be within the range of normal background activity at Redoubt. AVO mentioned these changes and observations in an Information Statement on October 3. Later that same day, AVO issued a second Information Statement describing newly recognized, weak, anomalous seismicity at Redoubt. The message emphasized that an eruption was not a certain outcome of the new activity, and that AVO would expect a significant increase in seismicity to occur prior to an eruption.

Airborne gas measurements on October 13 indicated significant levels of magmatic degassing $\left(\mathrm{CO}_{2}, \mathrm{SO}_{2}\right.$, and $\mathrm{H}_{2} \mathrm{~S}$ ) for the first time at Redoubt since the 1989-90 eruption sequence (M. Doukas, USGS, oral commun., 2010). Consistent with this, by mid-October, the area of fumarolic activity atop the 1990 lava dome continued to enlarge (fig. 5) and vapor plumes were consistently visible. The icefield around the 1990 dome showed increasing signs of deformation and creep as crevasses opened and enlarged. Melt water flowing beneath the upper Drift glacier on the north flank of the volcano had enlarged the 5,600 ft (1,705 m) elevation hole in glacial ice to about $50 \mathrm{~m}$ (160 ft) in diameter; a faint vapor plume emanating from the hole supported the conclusion that warm water was flowing subglacially down the upper Drift glacier. Dark elongate debris tongues extended downslope from the mid-1960s vent area and other parts of the upper Drift glacier consistent with increased melting and mobilization of available debris within and beneath the ice (fig. 5). Together, these observations indicated that Redoubt's activity was outside its normal 'background' level and on November 5, AVO raised the Aviation Color Code to YELLOW and the Volcano Alert Level to ADVISORY. The message stated that unrest could be related to the influx of new magma into the crust below the volcano, but repeated the caveat that an eruption was not imminent or even certain. 


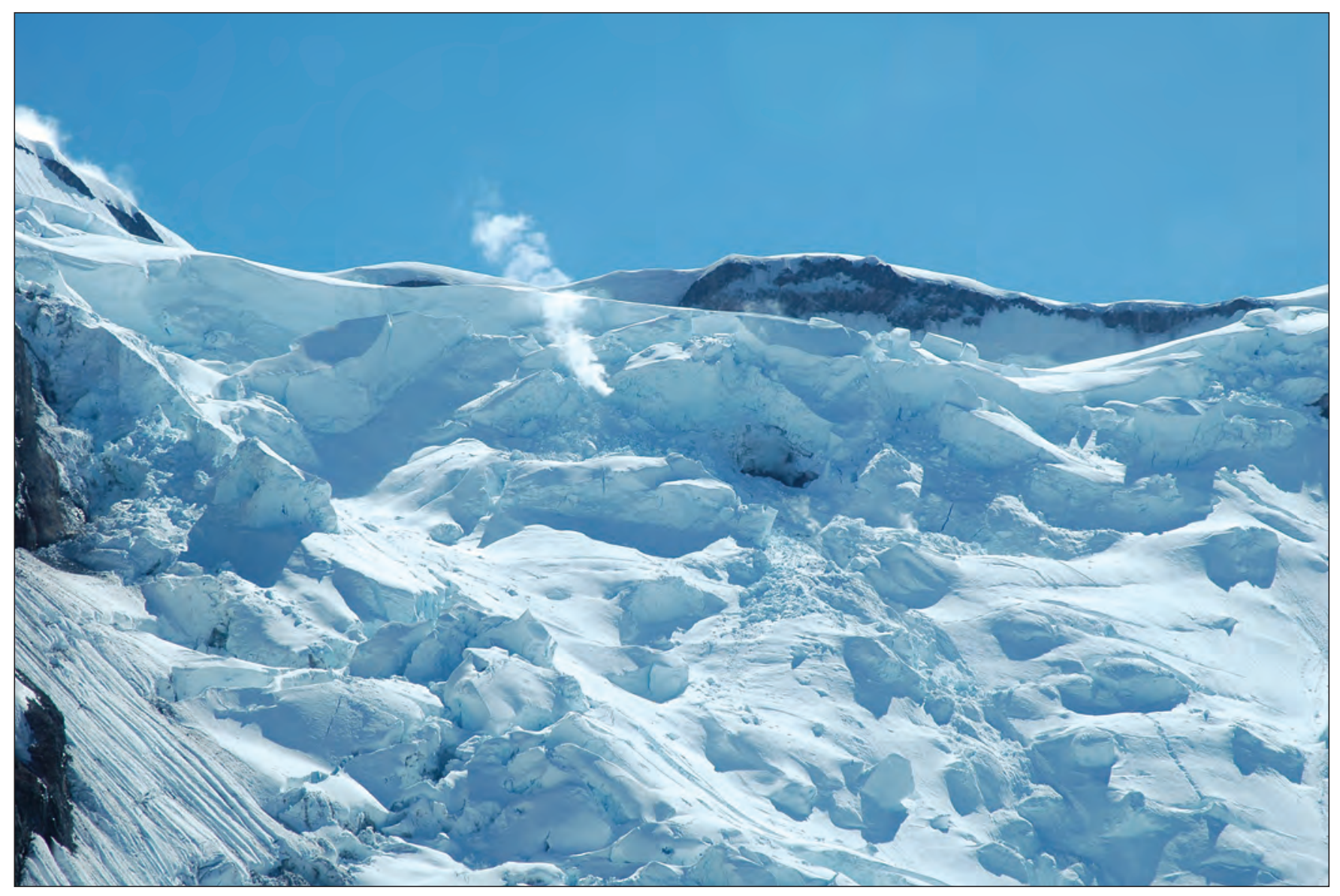

Figure 3. Fumarolic activity through glacial ice that covered the 1990 lava dome in the summit crater of Redoubt, August 7, 2008. Such a large opening (about 20-30 m [60-100 ft] across) through the ice exposing the 1990 lava dome and a persistent vapor plume had not been observed by AVO geologists working in the area in July. However, in previous years a smaller patch of exposed rock and an occasional weak vapor plume had been observed in approximately the same area. Photograph by J. Freymueller, AVO/ UAFGI. AVO database image at URL: http://www.avo.alaska.edu/images/image.php?id=31872. 


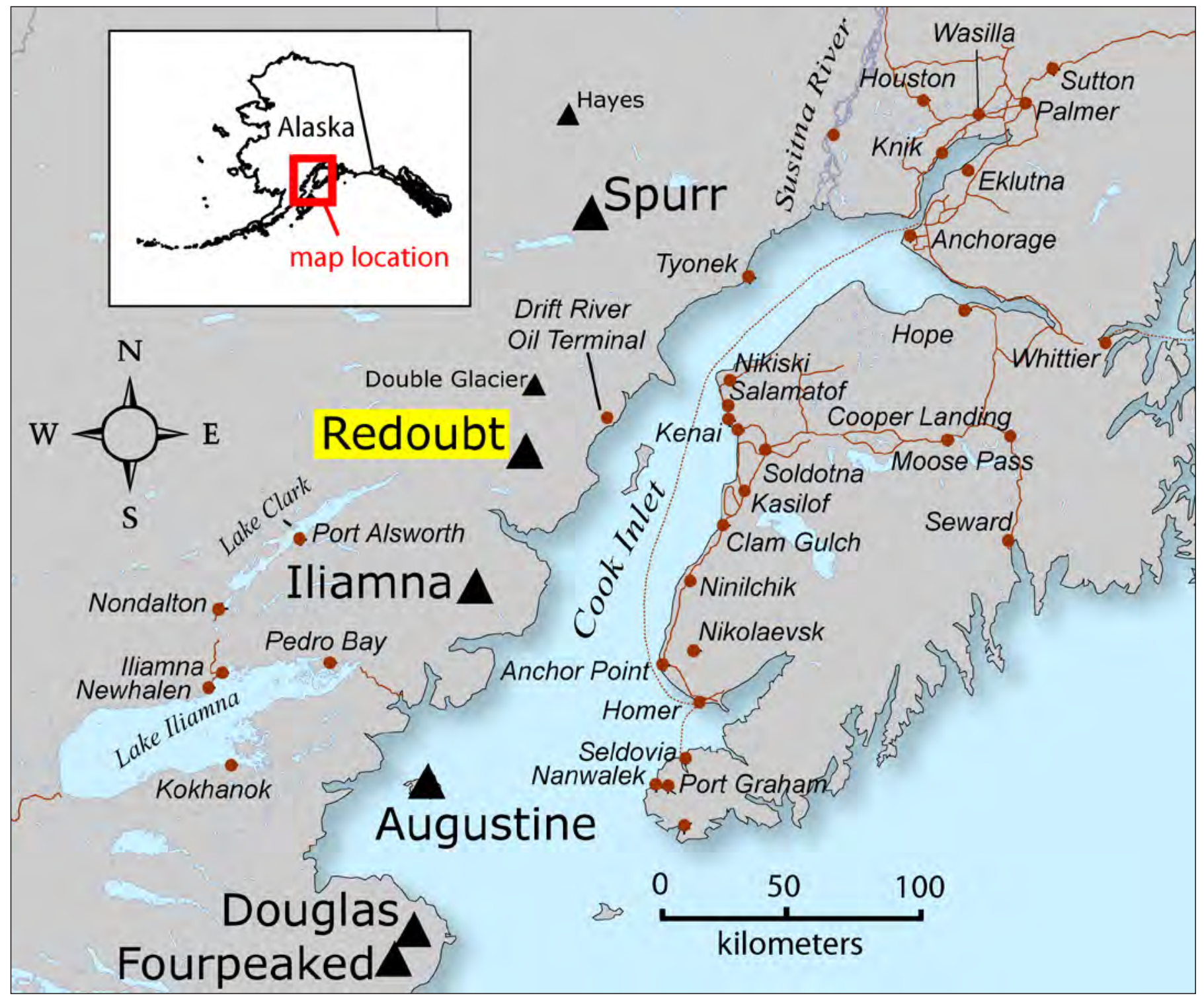

Figure 4. Location of Redoubt Volcano in south-central Alaska, other volcanoes, and place names in this section. Map courtesy J. Schaefer, AVO/ADGGS. 


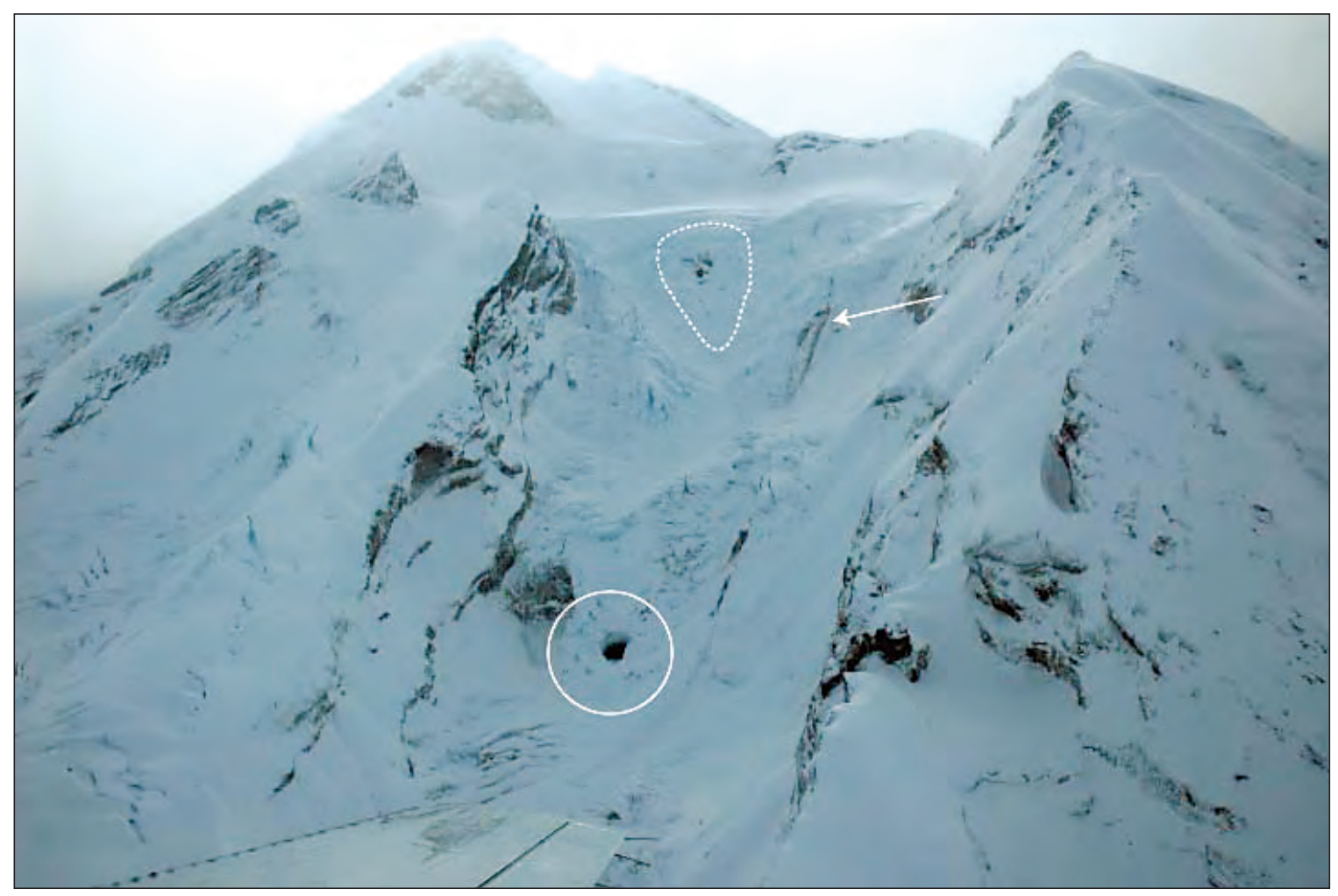

Figure 5. Summit area and upper north flank of Redoubt Volcano. The approximate outline of the ice-covered 1990 lava dome is shown by the dashed line. The new melt hole at about $5,600 \mathrm{ft}(1,700 \mathrm{~m})$ in the upper Drift gorge is circled below this, and the arrow indicates a recent flowage feature. Photograph by R.G. McGimsey, AVO/ USGS, October 13, 2008. AVO database image at URL: http://www.avo.alaska.edu/images/image. $p h p ? i d=15743$.

On November 7, AVO field crews documented anomalous water outflow in the Drift glacier gorge; figure 6 shows an active cascade of brown-colored debris and water atop the Drift glacier. Similar evidence of outflow was observed at several other points along the east side of the piedmont lobe of the Drift glacier. Pilots continued to report strong hydrogen-sulfide odors downwind of Redoubt into early winter.

Through the final weeks of 2008, the area of fumarolic activity in the summit crater and upper Drift glacier grew in size, exposing more bare rock atop the 1990 lava dome and the vent area for the mid-1960s dome. Glacial ice surrounding the fumarolic areas continued to deform in response to ongoing melting. Flowage features as long as $1 \mathrm{~km}$ (3,300 ft) consisting of snow, ice, and rock debris were occasionally observed extending from a number of point sources in the area of increased thermal output. In mid-December, AVO received a report from Kenai $82 \mathrm{~km}$ (51 mi) east of the volcano (fig. 4) of a visible water vapor cloud rising from the summit crater. Similar reports soon arrived from Homer, about $110 \mathrm{~km}$ (68 mi) southeast of the volcano (fig. 4). AVO's seismic network recorded several deep long-period events contemporaneous with these reports. The volcano ended the year at Aviation Color Code YELLOW and Volcano Alert Level ADVISORY.

Throughout the period of elevated unrest in late 2008, AVO monitoring demonstrated no clear deformation of the volcano and only a modest increase in the number 


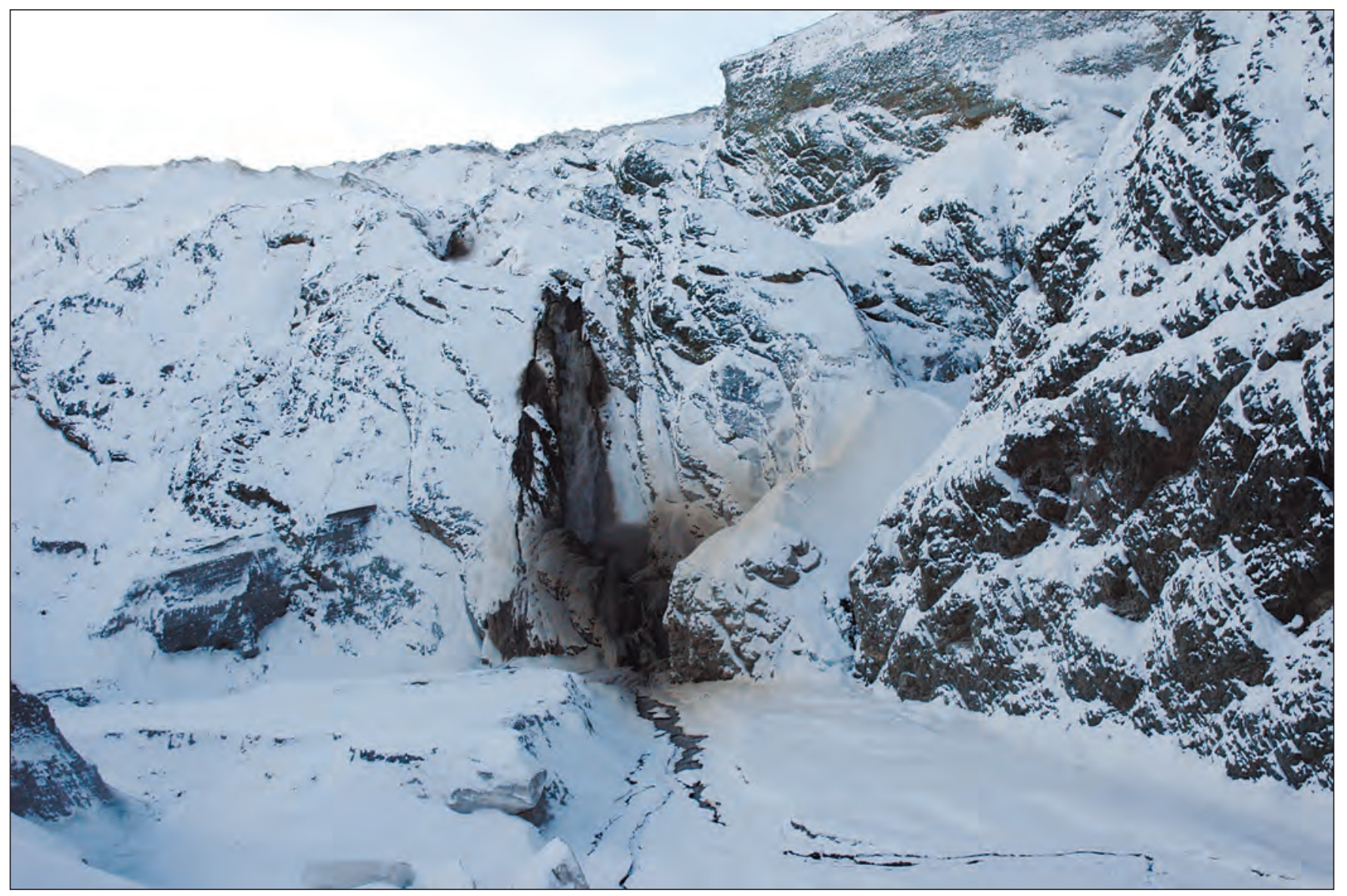

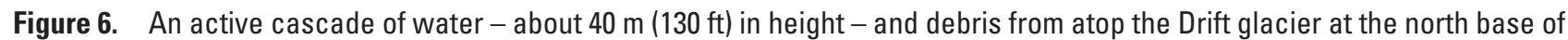
Redoubt Volcano, November 7, 2008. AVO sampled the turbid water and measured a temperature of $1.5^{\circ} \mathrm{C}$. Photograph by R.G. McGimsey, AVO/USGS. AVO database image URL: http://www.avo.alaska.edu/images/image.php?id=16049.

of low-frequency earthquakes, suggesting that any new magma, if present, was still at lower crustal depths (deeper than about $15 \mathrm{~km}$ or $9 \mathrm{mi})$. Beginning in November, AVO augmented monitoring by installing additional seismometers, web cameras, GPS stations, and other instrumentation near the volcano. AVO staff acquired Forward Looking Infrared (FLIR) images of the summit crater and north flank, collected meltwater draining down the Drift glacier canyon, and conducted several airborne gas measurement flights that documented increased magmatic gas output (M.P. Doukas, USGS, oral commun., 2010). Staff began internal discussions of unrest and eruption scenarios, compiled talking points to address media and public inquiries, and made contact with the Drift River Oil Terminal to brief them on the situation and possible outcomes.
Heavily ice-mantled Redoubt Volcano is located on the western side of Cook Inlet, $170 \mathrm{~km}$ (106 mi) southwest of Anchorage and 82 km (51 mi) west of Kenai, within Lake Clark National Park and Preserve. Redoubt is a stratovolcano with a reported summit elevation of 3,108 m (10,197 ft) above sea level. Recent eruptions occurred in 1902, 1966-68, 198990 (Waythomas and others, 1997), and 2009 (Bull, 2009). The 1989-90 and 2009 eruptions produced mudflows, or lahars, that traveled down the Drift River and partially flooded the Drift River Oil Terminal facility. Ash clouds produced by the 1989-90 and 2009 eruptions affected air traffic and resulted in minor or trace amounts of ash on communities in south-central Alaska (Miller and Chouet, 1994; Wallace and Schaefer, 2009). 


\section{Aniakchak Volcano}

CAVW\# 1102-09-

$56^{\circ} 54^{\prime} \mathrm{N} 158^{\circ} 13^{\prime} \mathrm{W}$

$1,341 \mathrm{~m}(4,400 \mathrm{ft})$

Alaska Peninsula

ANOMALOUS SEISMICITY

Weather related.

AVO seismic analysts noted a swarm of seismic events at Aniakchak during routine seismic checks of Alaskan volcanoes on March 8. The activity continued intermittently over the next week with events occurring as frequently as 5-10 per hour. Interpreting the significance of the signals was hampered by the fact that only a single station in the Aniakchak network, ANNW, was operating at the time. AVO increased seismic watch frequency for Aniakchak in response and contemplated organizing a winter-time field visit to restore more of the seismic network.

Subsequently, an evaluation of historical seismicity at Aniakchak during times of more complete network operation suggested that the anomalous signals were likely weather-related (Katrina Jacobs, AVO/UAFGI, written commun., 2008). Similar swarms had occurred on a number of occasions between 2005 and 2008, but none were typical multi-station volcanic events and all showed a strong correlation with time of day. Years of maintenance efforts at the Aniakchak network documented a strong vulnerability of sites to heavy icing that could have been responsible for the intermittent seismic signals. Based on this, an AVO field response was canceled.

Aniakchak is a circular caldera $10 \mathrm{~km}(6.2 \mathrm{mi})$ in diameter and as deep as $1 \mathrm{~km}(3,280 \mathrm{ft})$ from the rim to the caldera floor (fig. 7). The caldera formed during a catastrophic eruption of some $75 \mathrm{~km}^{3}\left(18 \mathrm{mi}^{3}\right)$ of material about 3,400 years ago (Miller and Smith, 1987; Dreher and others, 2005). Numerous lava domes, lava flows, and scoria cones occupy the interior of the caldera (Neal and others, 2001); the largest intracaldera cone is Vent Mountain, $2.5 \mathrm{~km}$ (1.5 mi) in diameter and rising $430 \mathrm{~m}(1,410 \mathrm{ft})$ above the floor of the caldera. The only historical eruption of Aniakchak, a powerful explosive event that covered a large portion of the eastern Alaska Peninsula with ash, occurred in 1931 (Nicholson, 2003). 


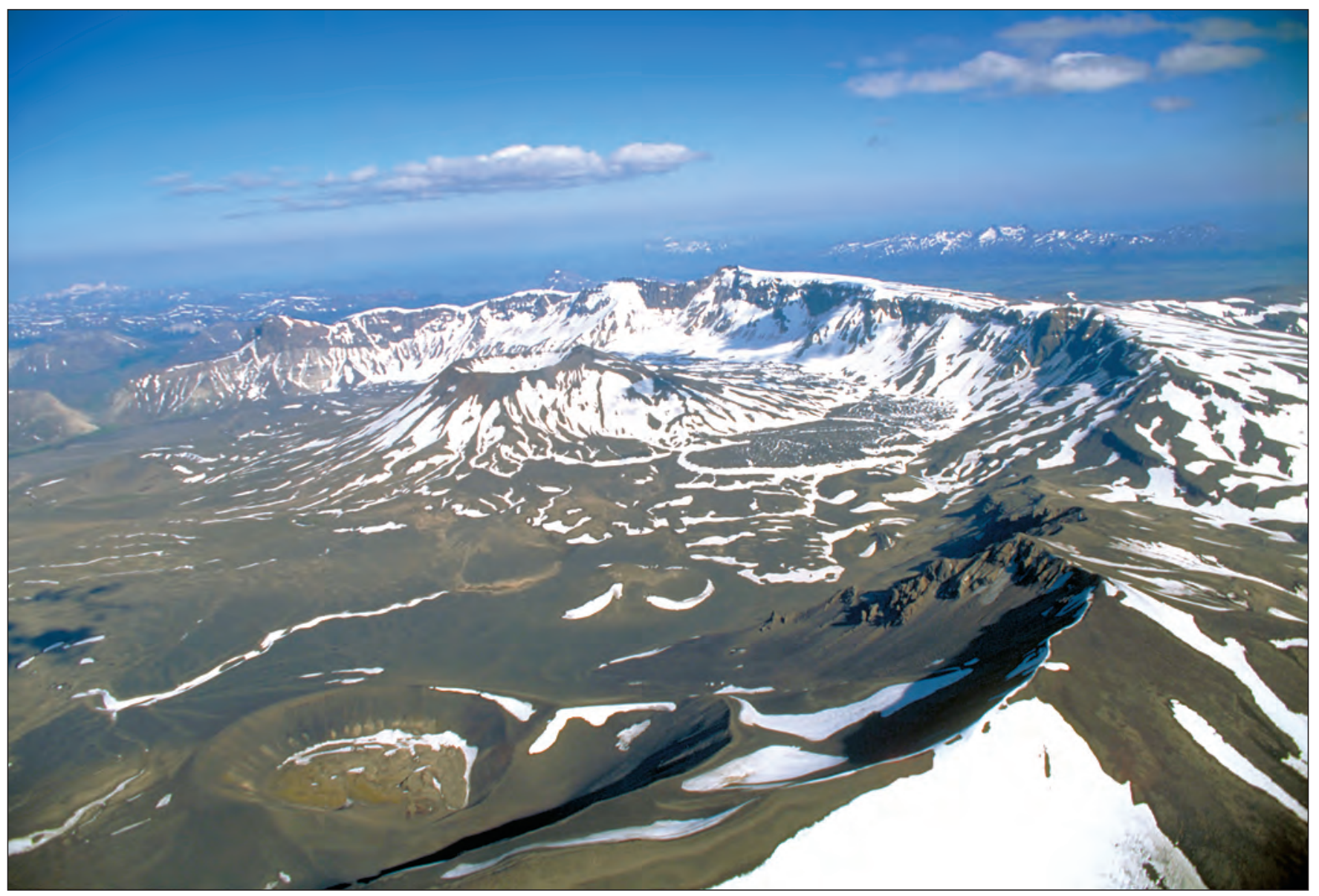

Figure 7. Aerial view of the western portion of 10-km-diameter (6.2 mi) Aniakchak caldera on the Alaska Peninsula. The 1931 tephra cone is in the foreground at lower left. In the middle ground is Vent Mountain, a complex spatter and scoria cone with no record of historical eruptions. View is to the south. Photograph by R. G. McGimsey, AVO/USGS, June 28, 1997. AVO database image URL: http://www.avo.alaska.edu/images/image.php?id=10524. 


\title{
Mount Veniaminof Volcano
}

\author{
CAVW\# 1102-07-
}

$56^{\circ} 12^{\prime} \mathrm{N} 159^{\circ} 24^{\prime} \mathrm{W}$

$2,507 \mathrm{~m}(8,225 \mathrm{ft})$

Alaska Peninsula

MINOR PHREATIC (?) ERUPTION

Intermittent, small, ash-poor plumes from the intracaldera cone.

Intermittent low-level activity at Veniaminof continued in 2008 with minor phreatic ash emissions and periods of slightly elevated seismicity. Beginning in mid-February, seismicity (in the form of 1-2 minute tremor bursts with occasional harmonic banding) became slightly more energetic and AVO staff noted vapor plumes in web camera images from Perryville, $35 \mathrm{~km}$ (22 mi) south of the volcano.

A weak ash emission event was captured on the AVO web camera on February 22, noted during routine analysis by AVO and reported via email by a watchful citizen, prompting AVO to issue a YELLOW/ADVISORY. Minor eruptions of ash occurred about once every 20-30 minutes over several hours, producing small plumes that rose at most about 300 $\mathrm{m}(1,000 \mathrm{ft})$ above the intracaldera cinder and spatter cone (fig. 8). Some of these small bursts could be correlated with a clear multi-station seismic event (fig. 9). Ash clouds dissipated rapidly and did not extend beyond the caldera rim; in between bursts, a white water vapor plume was common. These were similar to those seen during 2005 (McGimsey and others, 2007).

On February 23, only a white vapor plume rose above the cone. Tremor bursts continued, increasing in intensity (both number of discrete volcano-tectonic earthquakes (VTs) and longer tremor episodes) on February 29. In response, AVO initiated additional checks of seismic data for the volcano and implemented a Real Time Seismic Amplitude (RSAM) alarm for Veniaminof (Murray and Endo, 1992). A pilot reported ash to $10,000 \mathrm{ft}(3,050 \mathrm{~m})$ on February 29 and the NWS issued a SIGMET. Perryville residents using a telescope reported seeing large blocks, orange in color, thrown out of the plume during daylight hours on February 28. The lack of a thermal anomaly or night time reports of incandescence suggests these ballistic objects probably were altered and oxidized lava bombs rather than fresh, hot (and thus, 'glowing') magmatic ejecta.
In addition to more frequent analysis of seismicity, AVO initiated automatic ash dispersal runs using the PUFF model (Searcy and others, 1998) for hypothetical Veniaminof eruptions.

Seismicity and emissions decreased in early March and AVO discontinued the heightened seismic watch. A March 4 ASTER image showed a small vapor plume emanating from the intracaldera cone but no anomalous temperatures indicative of significant activity (R.L. Wessels, USGS, written commun., 2008).

On May 3, after several months of no further ash emission events, AVO downgraded Veniaminof to GREEN/ NORMAL, where it remained for the rest of 2008 and into 2009.

Veniaminof, an ice-clad, about $350-\mathrm{km}^{3}\left(84-\mathrm{mi}^{3}\right)$ andesite and dacite stratovolcano, is one of the largest and most active volcanoes of the Aleutian arc (Miller and others, 1998; Bacon and others, 2007). Located $775 \mathrm{~km}$ (482 mi) southwest of Anchorage and $35 \mathrm{~km}$ (22 mi) north of Perryville (fig. 1), the summit hosts an ice-filled, 10-km diameter (6.2 mi) caldera. Two Holocene caldera-forming eruptions are recorded in extensive pyroclastic-flow deposits around the volcano (Miller and Smith, 1987). Low-level, largely phreatic ash explosions from the approximately 350 -m-high $(1,150 \mathrm{ft})$ intracaldera cone have occurred intermittently since 2002, although the last significant magmatic eruption occurred in 1993-95 (Neal and others, 1995; McGimsey and Neal, 1996; Neal and others, 1996). This eruption was characterized by intermittent, lowlevel emissions of steam and ash, and production of a small lava flow that melted a pit in the caldera-ice field. During the more significant historical eruptions, ash plumes reached about $6,000 \mathrm{~m}(20,000 \mathrm{ft}) \mathrm{ASL}$ and produced ash fallout within about $40 \mathrm{~km}(25 \mathrm{mi})$ of the volcano. 


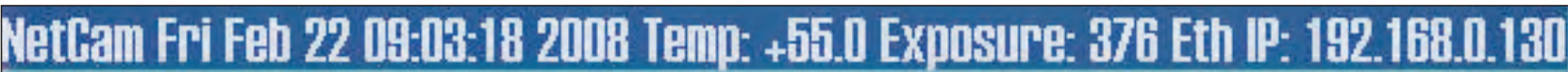

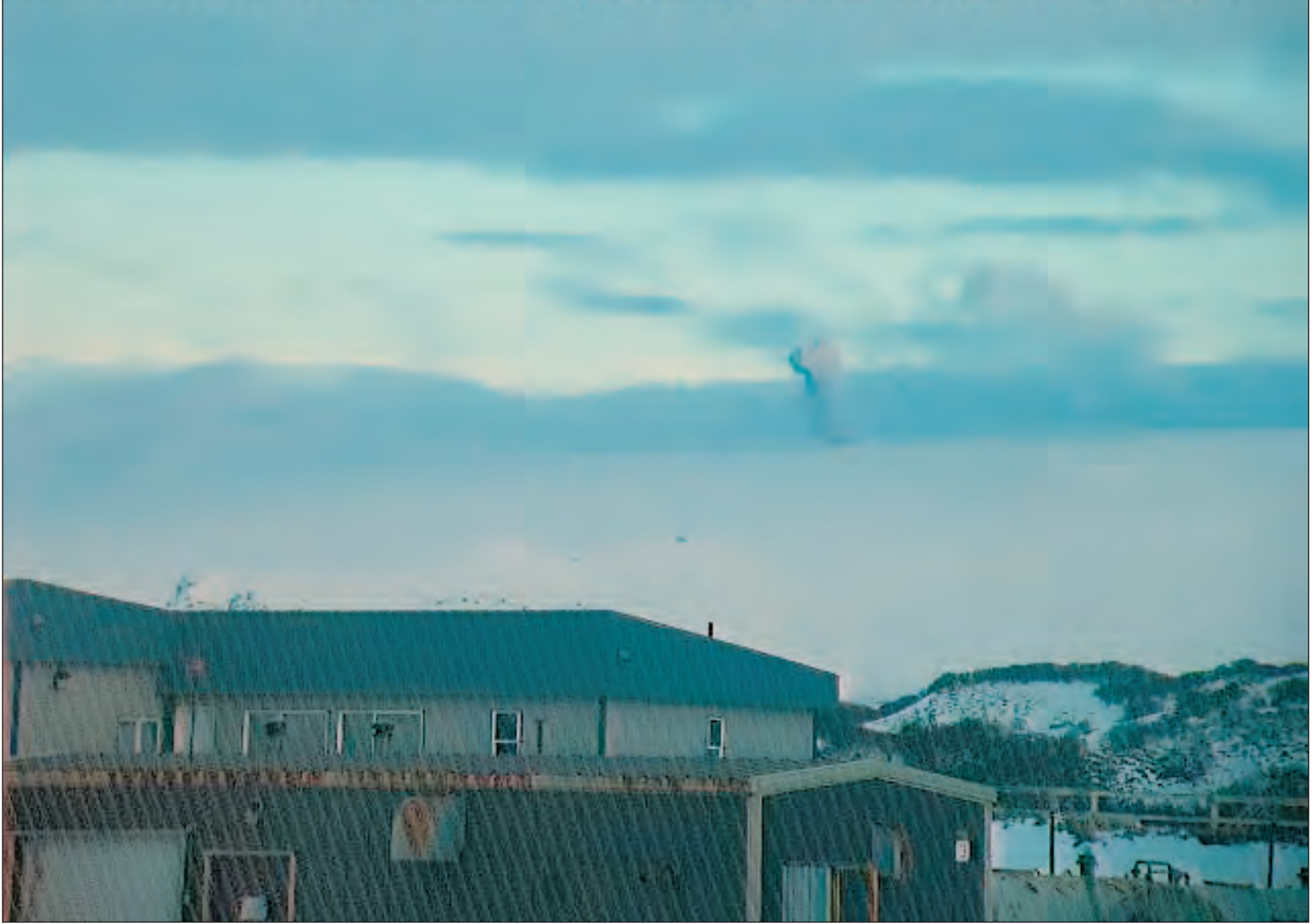

Figure 8. Small ash emission event at Veniaminof Volcano. AVO/USGS Perryville web camera image from February 22, 2008, at approximately 09:03 AKDT. Perryville buildings in the foreground; the village is about $35 \mathrm{~km}$ (22 mi) south of Veniaminof Volcano. AVO database image URL: http://www.avo.alaska.edu/images/image.php?id=14025. 

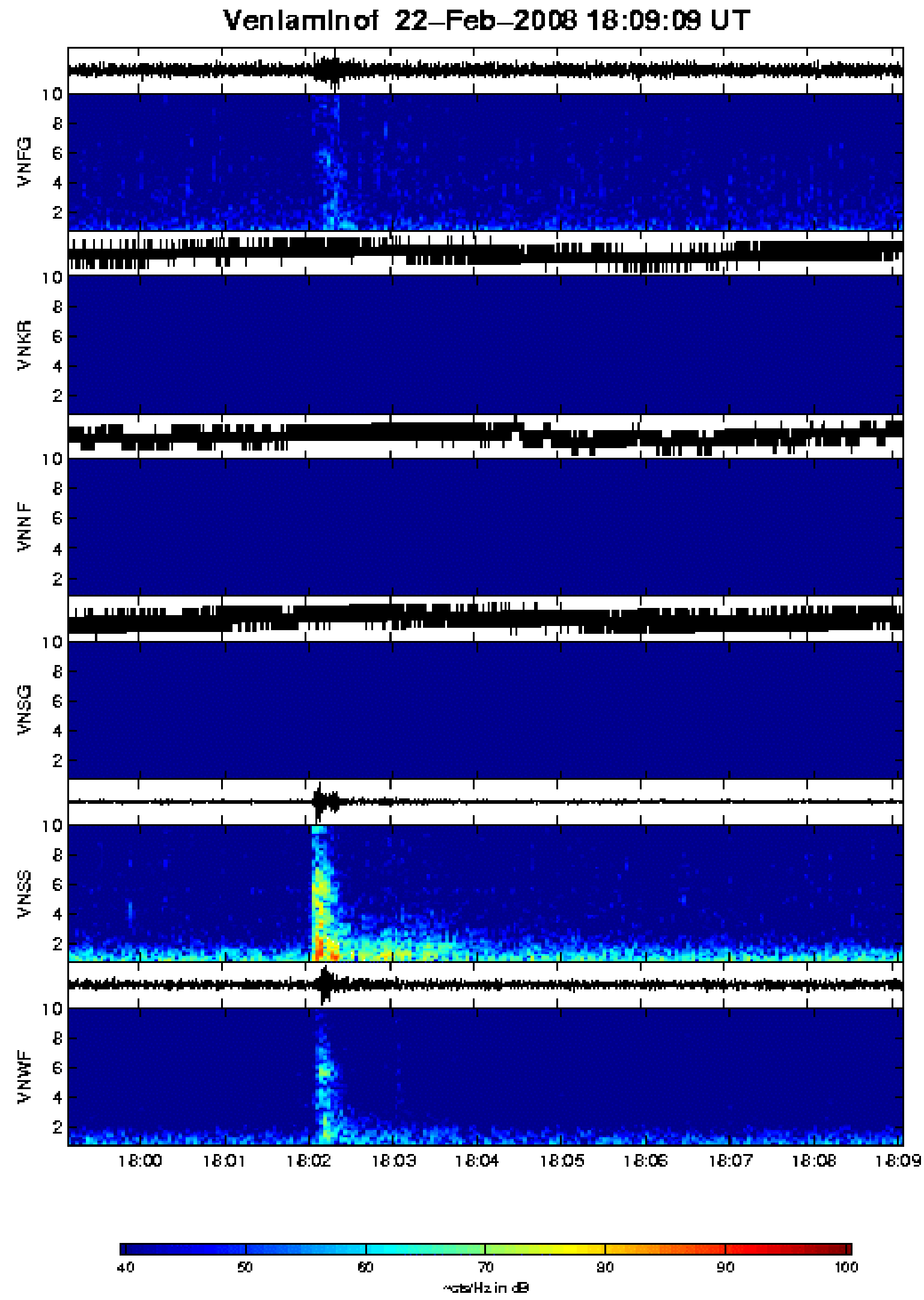

Figure 9. Seismicity related to the small 09:03 AKDT ash emission event at Veniaminof Volcano on February 22, 2008. The sharp onset of the event occurs just after 09:02 AKDT (1802 UTC) and the energy is much reduced by the 09:03 AKDT (1803 UTC) time stamp of the AV0 web camera image in figure 8. Graphic courtesy Scott Stihler, AVO/UAFGI. 


\author{
Shishaldin Volcano \\ CAVW\# 1101-36- \\ $54^{\circ} 45^{\prime} \mathrm{N} 163^{\circ} 58^{\prime} \mathrm{W}$ \\ $2,857 \mathrm{~m}(9,373 \mathrm{ft})$ \\ Unimak Island, eastern Aleutian Islands \\ MINOR PHREATIC ASH (?) EMISSION EVENTS
}

AVO received a number of calls during 2008 regarding possible steam and ash emissions from Shishaldin. The first caller on January 8 reported a plume rising just a few thousand feet above the summit. On February 11, AVO received word from the National Weather Service of several pilot reports of a plume containing ash to an estimated 15,000 ft (4,600 m) ASL and extending south for about $25 \mathrm{mi}(40 \mathrm{~km})$. A check of seismicity showed nothing unusual that would reflect an increase in activity or ash emission. A one-time SIGMET was issued by National Weather Service. The following day, the USCG inquired about the status of the volcano and its potential for impacting operations in the area.

On June 3, AVO received a pilot report of a steam plume rising about 2,000 ft (610 m) above the summit. On July 27, AVO was contacted by a mariner from the fishing vessel Castle Cape who reported Shishaldin "puffing" on July 26 between about 8 p.m. and 12 a.m. local time. He described ash falling from the dissipating puffs. For all of these reports, there were no unequivocal correlative changes in seismicity, nor did any ash signal or thermal anomaly appear in satellite images. On July 29, AVO staff flying by Shishaldin from Dutch Harbor en route to Anchorage noted a faint wisp of vapor from the summit crater; there was a hint of dark discoloration high on the east flank, but views were quite distant. AVO received images of the volcano from a NOAA scientist on July 30 and several additional pilot reports of a steam plume from Shishaldin arrived on August 3. It is possible that this spike in reports reflected increased vigilance on the part of pilots and others traveling in the Aleutians in the wake of the highly explosive and continuing eruption of Okmok Volcano (next section) about $300 \mathrm{~km}$ (190 mi) west of Shishaldin. Shishaldin also is easily visible from the air on approach into Dutch Harbor.

AVO staff and colleagues from the Plate Boundary Observatory field team conducted instrument maintenance, installed 13 GPS stations, a broadband seismometer, 6 borehole tiltmeters, and a web camera, and relocated 4 seismic stations on Unimak Island from July 30 to August 22, 2008. They noted no obvious evidence of recent ash fall on the surface although they did observe some discoloration of the upper ice and snow cover, along with typical, weak fumarolic emission from the summit crater (figs. 10 and 11).

Shishaldin Volcano, located on Unimak Island in the eastern Aleutians, is a large, symmetrical cone about $16 \mathrm{~km}$ (10 mi) in diameter at the base (fig. 12). Shishaldin is the highest peak in the Aleutian Islands. Its last significant eruption was in 1999 (Nye and others, 2002), however, occasional dustings of windblown or possibly phreatic ash on the upper flanks attest to a hot and active shallow hydrothermal system. Monitored with a seismic network, Shishaldin has a high level of normal background seismicity. In addition, its steep-walled summit crater produces a frequently visible vapor plume (figs. 12 and $\underline{13}$ ) and satellite imagery with a high zenith angle will sometimes capture a striking thermal anomaly. AVO frequently receives calls from airlines and mariners about plumes and possible ash deposits high on the slopes of Shishaldin. 


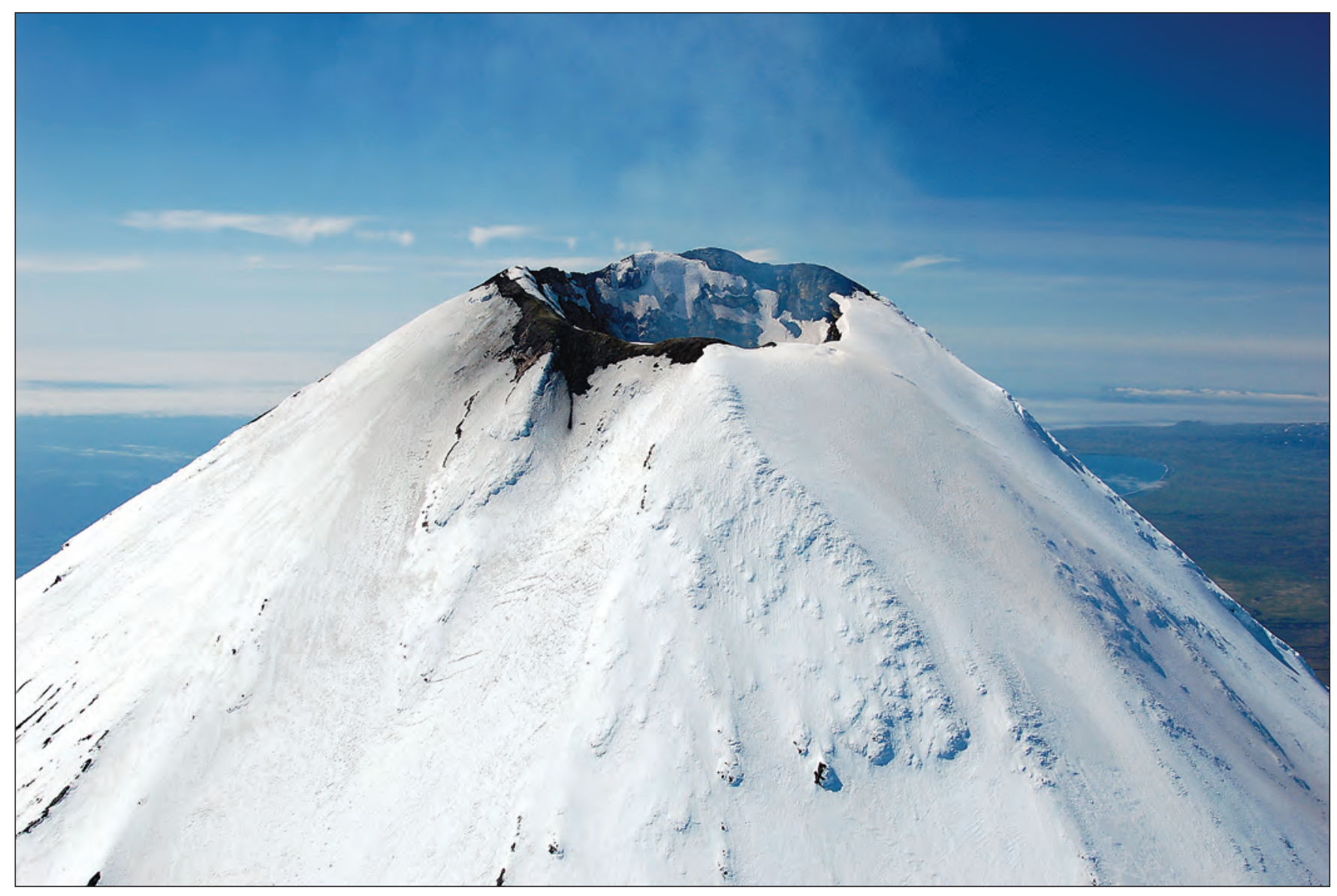

Figure 10. Summit area of Shishaldin Volcano on August 1, 2008. A weak plume of water vapor and possibly other volcanic gas emanates from the steep-walled summit crater. Dark discoloration of the snow and ice field below the rim is likely wind and water remobilized fragmental debris from the rim area. Photograph by C. Read, AVO/USGS. AVO database image URL: http://www.avo. alaska.edu/images/image.php?id=15239. 


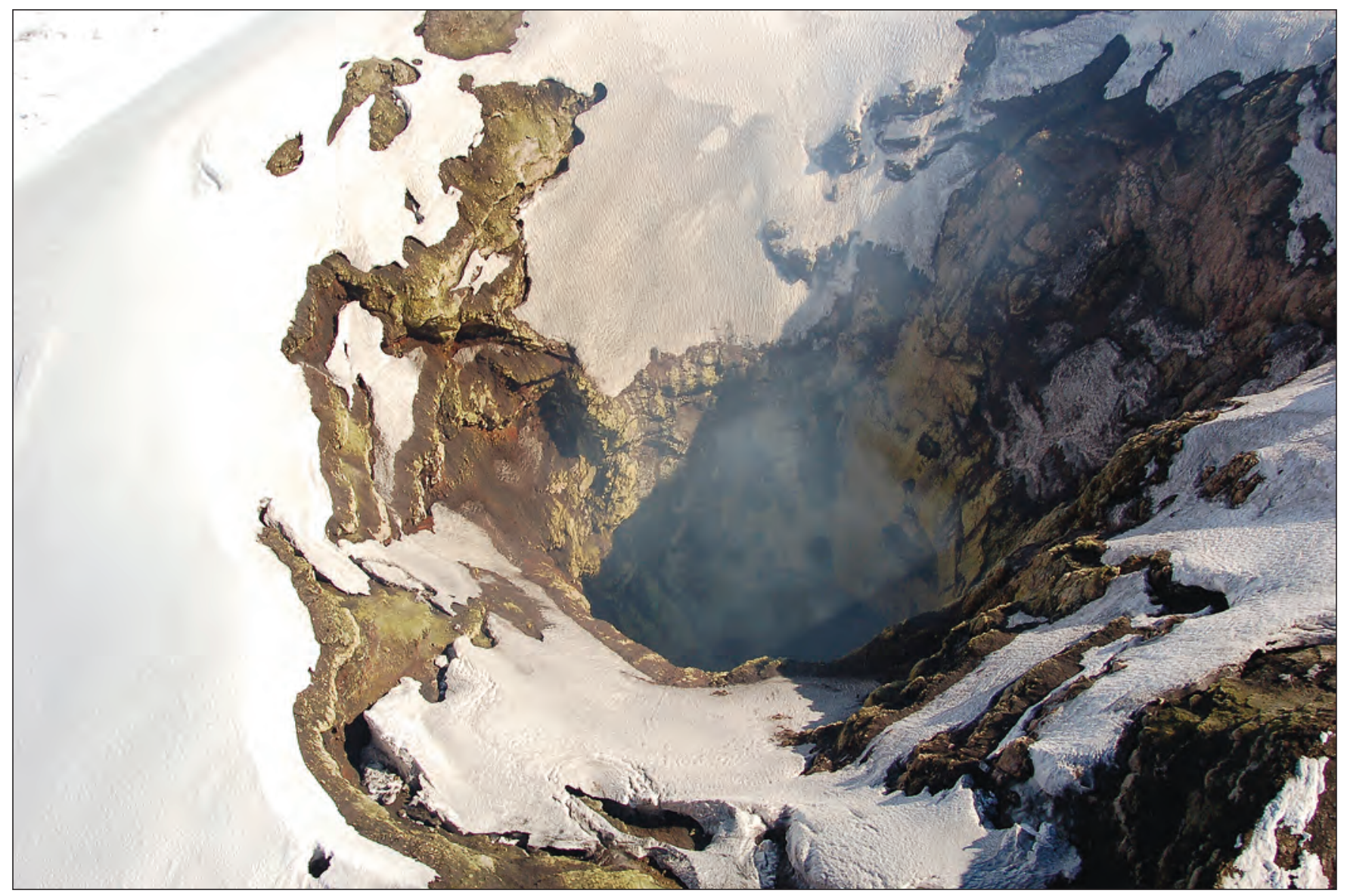

Figure 11. Summit crater of Shishaldin Volcano on August 1, 2008. The crater diameter is about $100 \mathrm{~m}$ (330 $\mathrm{ft}$ ) narrowing to an inner throat that is about $30 \mathrm{~m} \mathrm{(100} \mathrm{ft)} \mathrm{across} \mathrm{(Vergniolle} \mathrm{and} \mathrm{others,} \mathrm{2004).} \mathrm{The} \mathrm{depth} \mathrm{of} \mathrm{the} \mathrm{open} \mathrm{conduit} \mathrm{is} \mathrm{highly} \mathrm{uncertain} \mathrm{and}$ likely variable through time; Dehn and others (2002) estimated a depth of $400 \mathrm{~m}(1,300 \mathrm{ft})$ based on satellite image analysis and seismic source studies. Photograph by C. Read, AVO/USGS.AVO database image URL http://www.avo.alaska.edu/images/image. php?id=31882. 


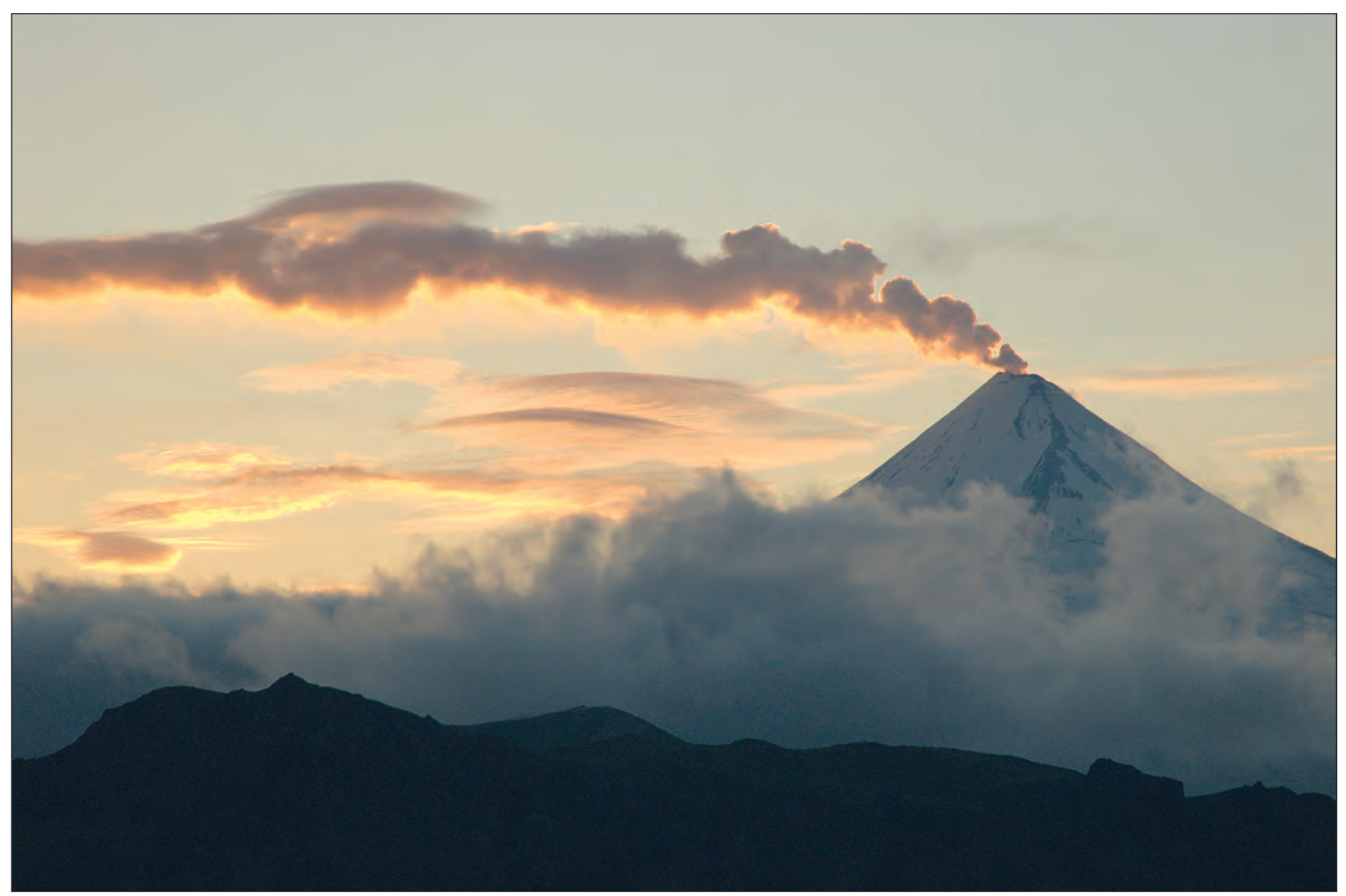

Figure 12. A particularly spectacular vapor plume from the summit of Shishaldin Volcano on August 15, 2008. This kind of activity often prompts pilot and mariner reports of possible eruptive activity. Seismicity during episodes of vigorous fumarolic emission such as this is not diagnostic of an increase in activity. Photograph by C. Read, AVO/USGS. AVO database image URL: http://www. avo.alaska.edu/images/image.php?id=15244. 


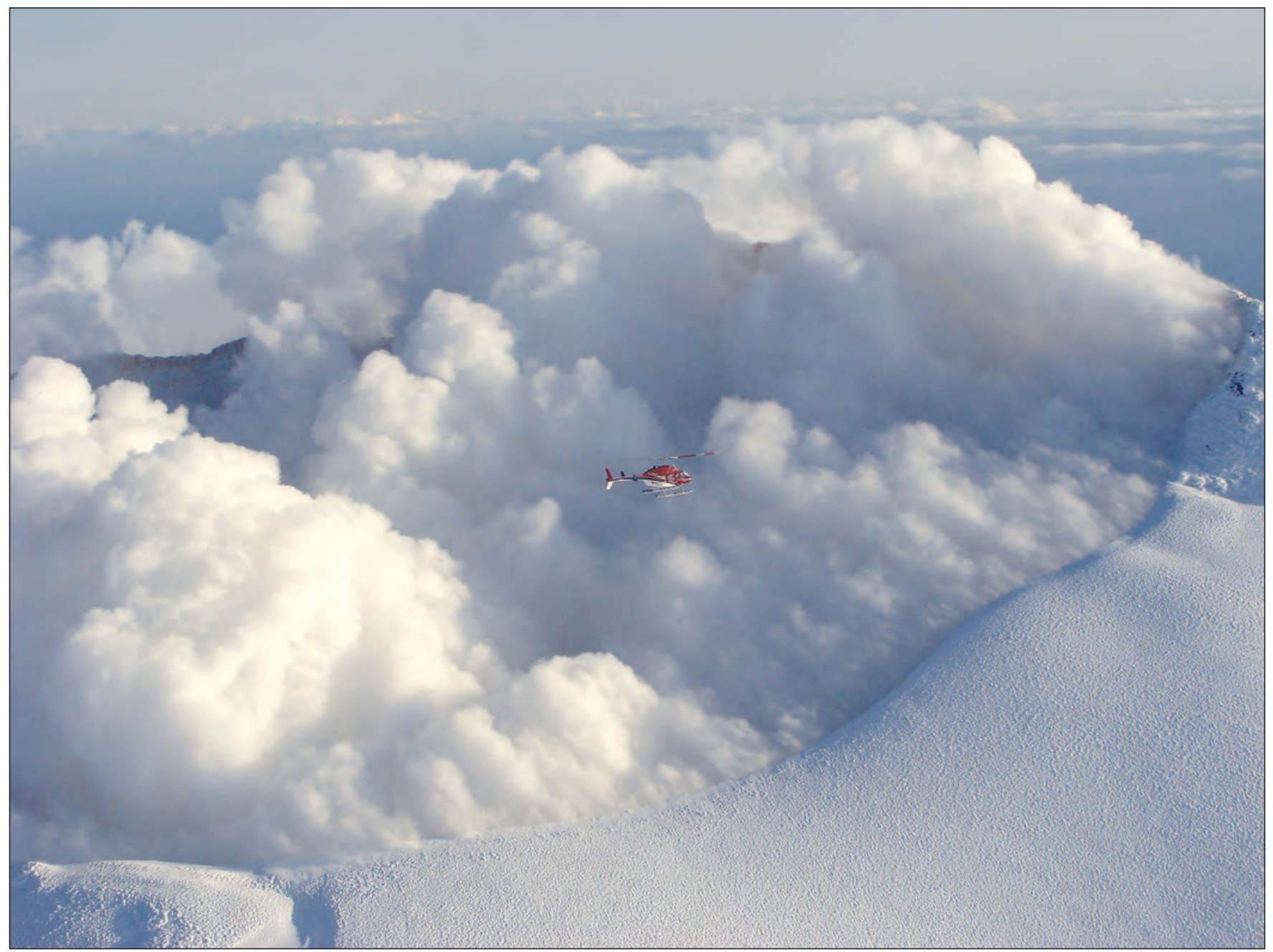

Figure 13. Summit crater of Shishaldin Volcano on October 12, 2008. The $100-\mathrm{m}(330 \mathrm{ft})$ wide summit crater is filled with clouds of water vapor. Note helicopter for scale. Photograph by Mike Fell, Pathfinder Aviation ${ }^{\odot}$, used with permission. AVO database image URL: http://www.avo.alaska.edu/images/image.php?id=16031. 


\section{Unalaska Bay, near Makushin Volcano}

\section{CAVW\# none}

$53^{\circ} 57^{\prime} \mathrm{N} 166^{\circ} 58^{\prime} \mathrm{W}$

Submarine

Unalaska Island, eastern Aleutian Islands

DISCOLORED SEAWATER/BUBBLES IN UNALASKA BAY

Likely due to groundwater discharge, not volcanic.

On June 27, a USCG officer made a report to NOAA about a persistent area of discolored seawater in Unalaska Bay, about 3 km (1.9 mi) north of Dutch Harbor and in-line with Wide Bay cone and Table Top volcano, two satellite vents that are part of the larger Makushin volcanic field (McConnell and others, 1998). The officer stated that he had noticed this discoloration for approximately 2 years. NOAA forwarded the report and photographs via email to AVO on July 2.

AVO considered three possibilities for the discoloration: (1) ship discharge, (2) hydrothermal venting from a submarine volcanic cone, and (3) groundwater discharge or venting through the seafloor. A transient ship discharge was quickly ruled out, due to the phenomenon's consistent presence and location. Discriminating between a volcanic or groundwater explanation for the discoloration is difficult without further investigation. Unalaska Bay is a normal location for seismic activity, and a quick examination of AVO's seismic data for the area revealed nothing beyond background. On July 11, the NOAA ship Oscar Dyson conducted a conductivity, temperature, and depth (CDT) study near the site, and on July 24, the NOAA ship Fairweather conducted another CDT study and bathymetric mapping. The Oscar Dyson's CTD study detected nothing unusual but the study was done too far from the apparent source to rule out a possible hydrothermal plume. The Fairweather's survey showed seafloor mounds in the vicinity, possibly emitting plumes, but not directly under the anomaly. Conductivity and temperature measurements did not support a volcanic source. Further data collection and analysis in August by NOAA showed numerous sites of probable bubble streams coming out on the seafloor (seen in 2007 imagery). Another NOAA ship reported similar discolored water in a different, but nearby location in July 2008. At this time, we conclude that the multiple locations of discolored water at the surface and at the seafloor point to likely groundwater discharge, possibly through a fault system, rather than a submarine volcanic plume. 


\section{Okmok Volcano}

CAVW\# 1101-29-

$53^{\circ} 25^{\prime} \mathrm{N} 168^{\circ} 08^{\prime} \mathrm{W}$

$1,073 \mathrm{~m}(3,520 \mathrm{ft})$

Umnak Island, eastern Aleutian Islands

5 WEEKS OF PHREATOMAGMATIC ERUPTION FROM MULTIPLE VENTS ON CALDERA FLOOR

Substantial to severe ash fall on Umnak Island, pyroclastic surges, lahars, ash clouds to 52,000 ft (16 km).

Okmok Volcano, a 10-km (6.2-mi) diameter Holocene caldera system in the central Aleutians (fig. 14), began a protracted explosive eruption on July 12 . The opening explosions consumed a portion of intracaldera Cone D within the east-central sector of the caldera, reaming several new craters into the caldera floor. Eruptive activity began only a few hours after a subtle increase in the rate of earthquakes followed by a short swarm sequence, both noted only in retrospect. Over the next 5 weeks, several hundred million cubic meters of tephra and lahar deposits blanketed much of northeast Umnak Island. Within the caldera, nearly continuous hydrovolcanic explosions accumulated many tens of meters of wet, mostly fine-grained tephra. Explosive activity completely disrupted existing groundwater and standing water bodies within the caldera, formed new lakes, and constructed a new tephra cone about 100-200 m (330-660 ft) high. This eruption was the first dominantly phreatomagmatic volcanic event in the United States since the Ukinrek Maars eruption in 1977. The following summary is taken largely from Larsen and others (2009).

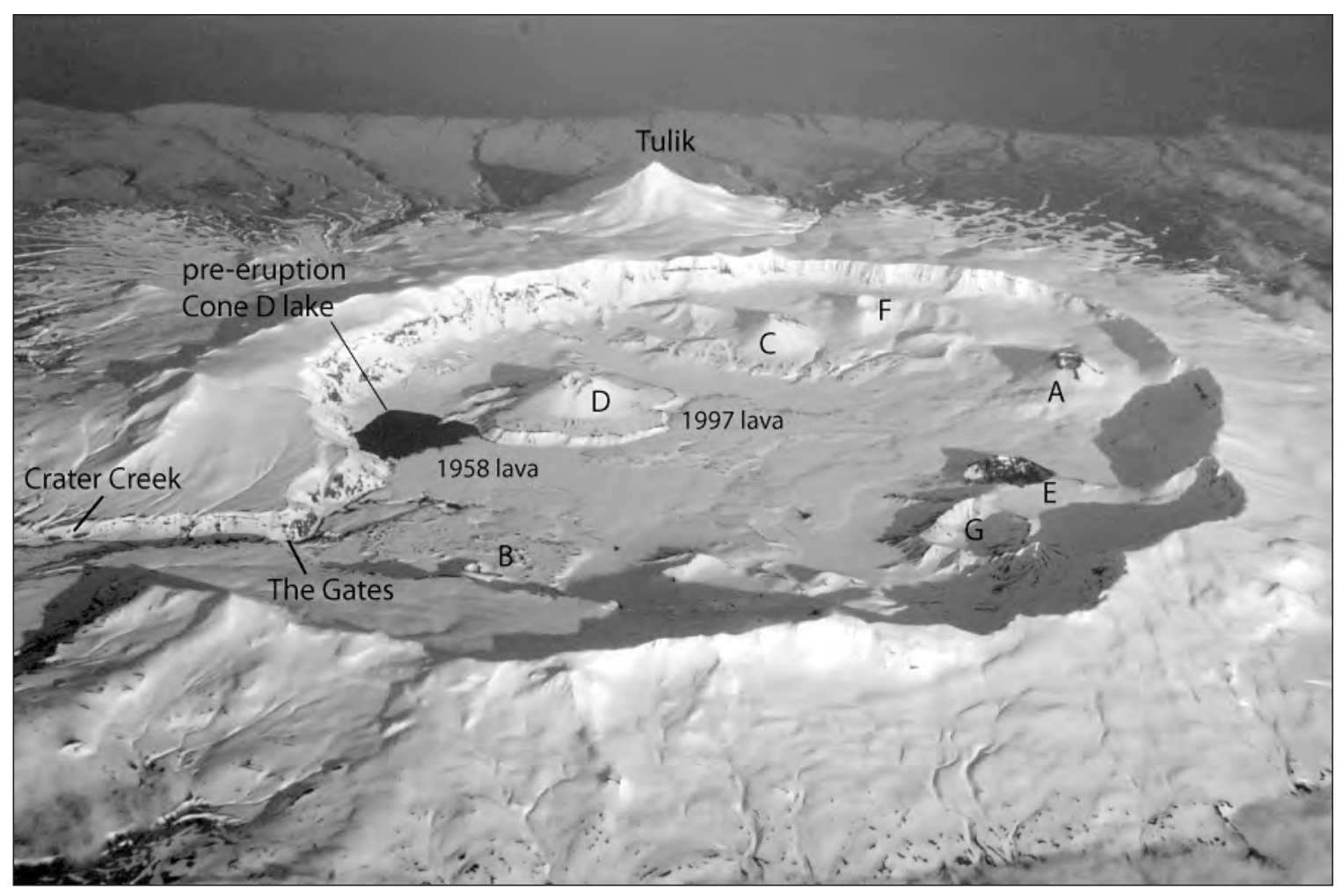

Figure 14. Aerial view of Okmok Caldera, June 7, 2007. Major features discussed in the text are labeled; letters refer to individual vents as identified by Byers (1959). South at top. Photograph by C. Read, AVO/USGS. AVO database image URL: http://www.avo.alaska.edu/images/image.php?id=13283. 
Other than the seismicity recognized in hindsight, AVO noted no clear signs of precursory unrest at Okmok prior to the eruption onset. In fact, during the 2 months prior to July 12 , Okmok produced only three earthquakes and no tremor episodes (intermittent tremor episodes had been recorded since the seismic network was installed in 2003 and had continued into mid-2005; Reyes and McNutt, 2008). Campaign and continuous GPS data had recorded nearly continuous inflation from 1997 to 2005, quiescence between 2005 and 2007, and notable (but not unprecedented) inflation in early 2008. Preeruptive displacements measured by GPS and InSAR indicated inflation of a pressure source about 2.6-3.2 km (1.6-2.0 mi) below sea level and underneath the approximate center of the caldera (Lu and others, 2005; Fournier and others, 2009).

AVO was first notified of the eruption by the USCG who had been contacted by the caretaker of Bering Pacific Ranch at Fort Glenn [Fort Glenn is a former U.S. Army base that now houses a cattle ranch operation about $10 \mathrm{~km}(6.2 \mathrm{mi})$ southeast of the caldera rim]. The caretaker and his family reported wet volcanic ash falling as they were evacuating the island first by helicopter and later by boat. An immediate check of Okmok seismicity by the AVO duty scientist confirmed that an eruption was in progress. AVO issued a notice of the eruption declaring Aviation Color Code RED and Volcano Alert Level WARNING and commenced 24-hour operations to respond to the event.

In addition to 24-hour staffing of the operations room in Anchorage, AVO mounted two helicopter-supported field responses to the eruption. The first operated from Unalaska between July 29 and August 5 and the second was based at Fort Glenn over a week in mid-September about 3 weeks after the eruption had ended. AVO received photographs taken by Fort Glenn ranch caretaker Lonnie Kennedy on several occasions. These photographs along with images from commercial and USCG aircraft, satellite imagery, and mariner accounts provided critical visual documentation of the eruption through time.
The most energetic phase of the eruption occurred over the first 10 hours of activity on July 12 . The first satellite images of the ash plume were geostationary operational environmental satellite (GOES) images starting at 20:00 UTC on July 12. By 22:12 UTC, the ash cloud extended east over much of Unalaska Island (fig. 15). Both geometric image analysis of GOES and comparison of cloud motion with the PUFF ash dispersion model indicated a maximum initial column height of approximately $16 \mathrm{~km}(52,000 \mathrm{ft})$ ASL. Photographs of the eruption column by crews of a USCG C-130 and an Alaska Airlines jet taken about 5-6 hours into the eruption show a vertical, gray, ash-rich column rising into meteorological cloud layers; the top of the eruption plume appeared white and was estimated visually to be 30,000 $35,000 \mathrm{ft}(9,100 \mathrm{~m}-10,700 \mathrm{~m})$ ASL. The ground was obscured and the aircraft too distant to make out any detail at the base of the eruption column.

The opening explosions and heavy tephra fall destroyed or disabled several AVO seismometers and continuously recording GPS instruments, however the remaining network density was sufficient to track the eruption. From July 13 through the end of the month, seismicity varied but remained well below the intensity of the opening eruption sequence on July 12. Eruption columns and clouds seen in satellite imagery and by passing aircraft varied significantly in altitude although these changes were not often in phase with recorded seismic amplitude (Larsen and others, 2009; table 5). Characteristics of most eruption clouds implicated the continuous involvement of water in the eruption process. On July 13, a Moderate Resolution Imaging Spectroradiometer (MODIS) satellite image showed two plumes —one dark and ash rich and the other light in color and inferred to be very rich in water vapor-emanating from the eastern portion of the caldera floor. Between July 13 and 21, photographs from Alaska Airlines and aerial observations by AVO staff from a USCG plane showed a light-colored plume with a wide base and multiple potential sources of ash explosions (fig. 16). 


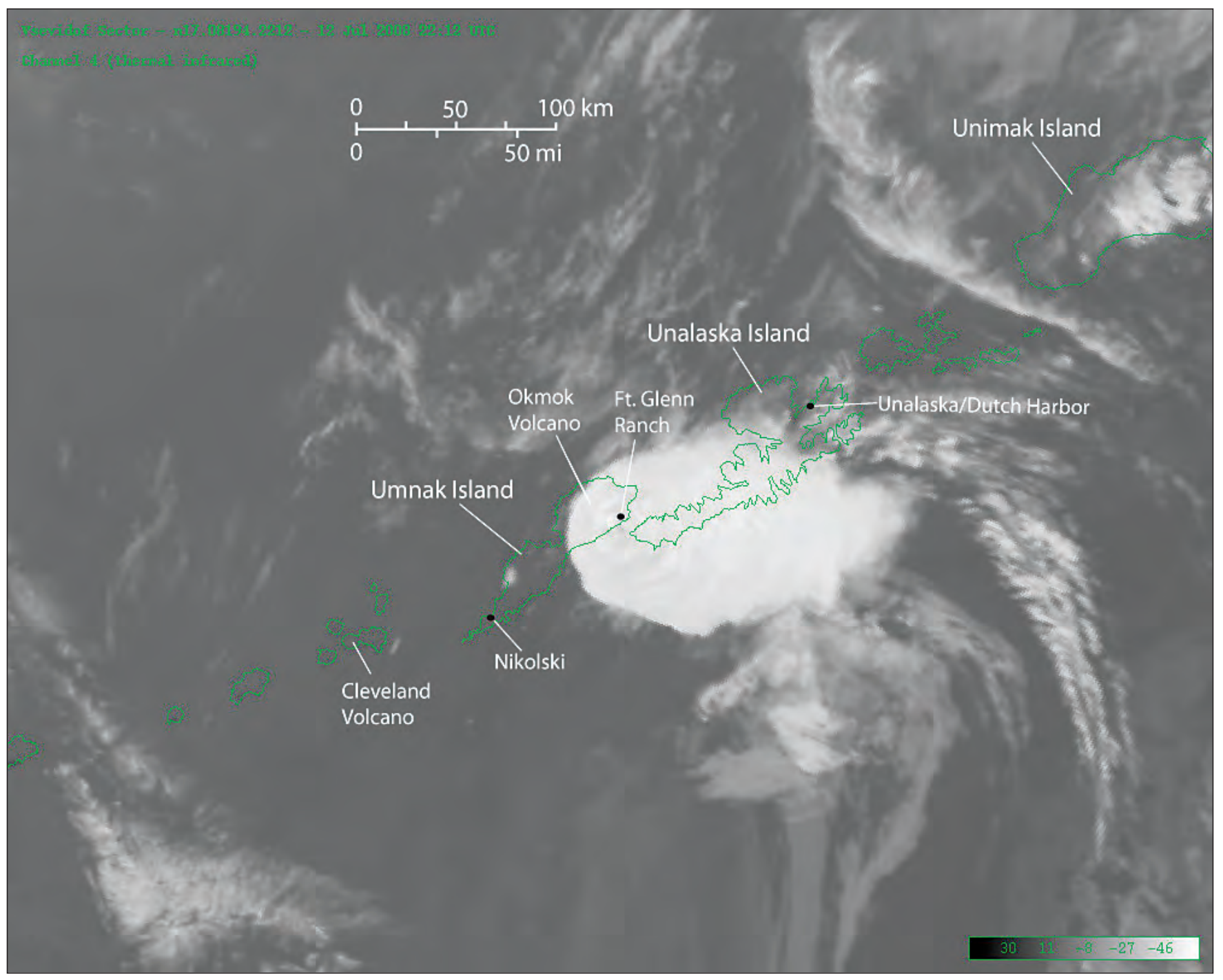

Figure 15. Thermal infrared channel from the July 12, 2008, 22:12 UTC GOES satellite image showing the eastward drifting Okmok eruption cloud. Gray scale in lower right is temperature in degrees Celsius. Image modified from original courtesy D.J. Schneider, AVO/USGS. AVO database image URL: http://www.avo.alaska.edu/images/image.php?id=14279. 


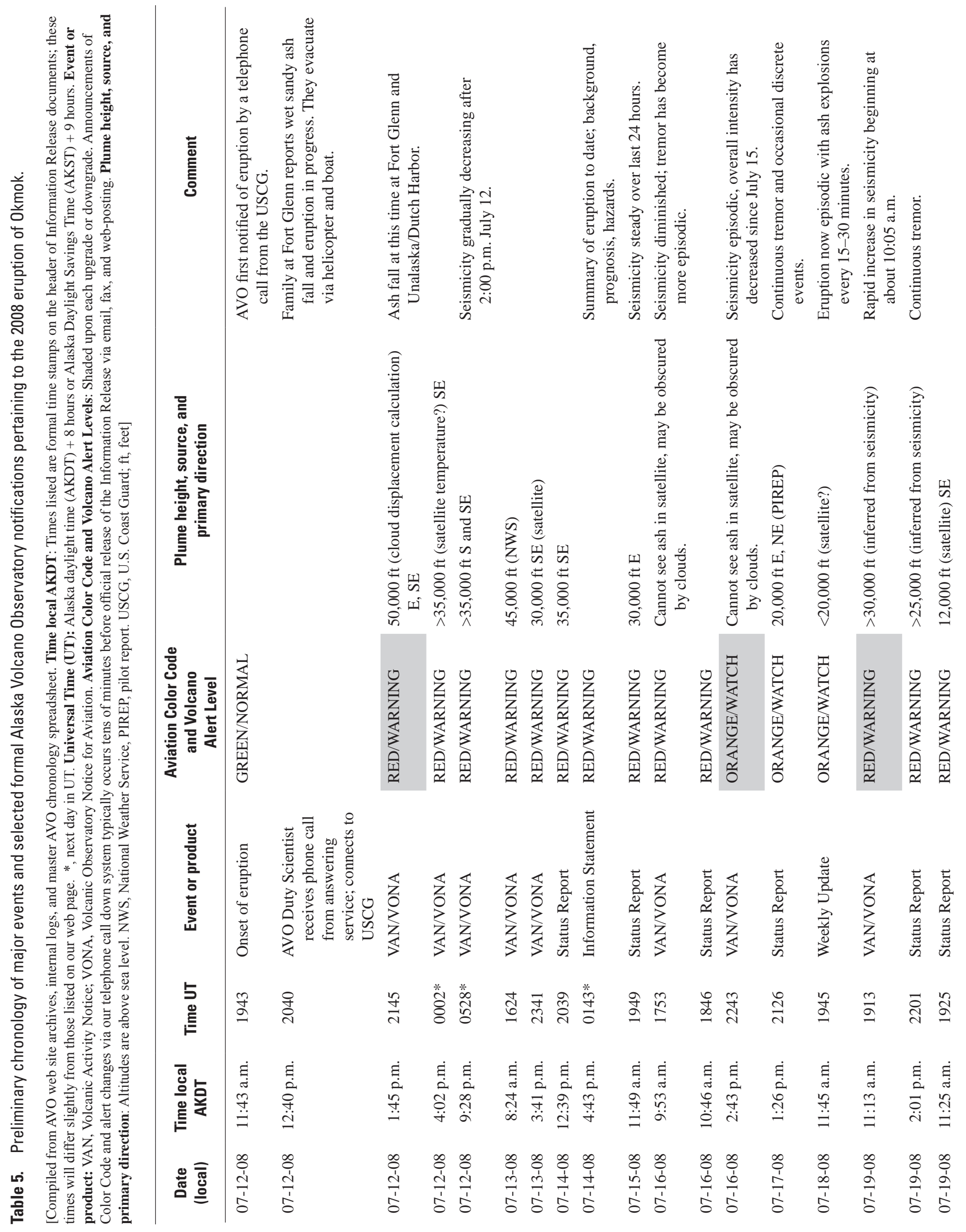



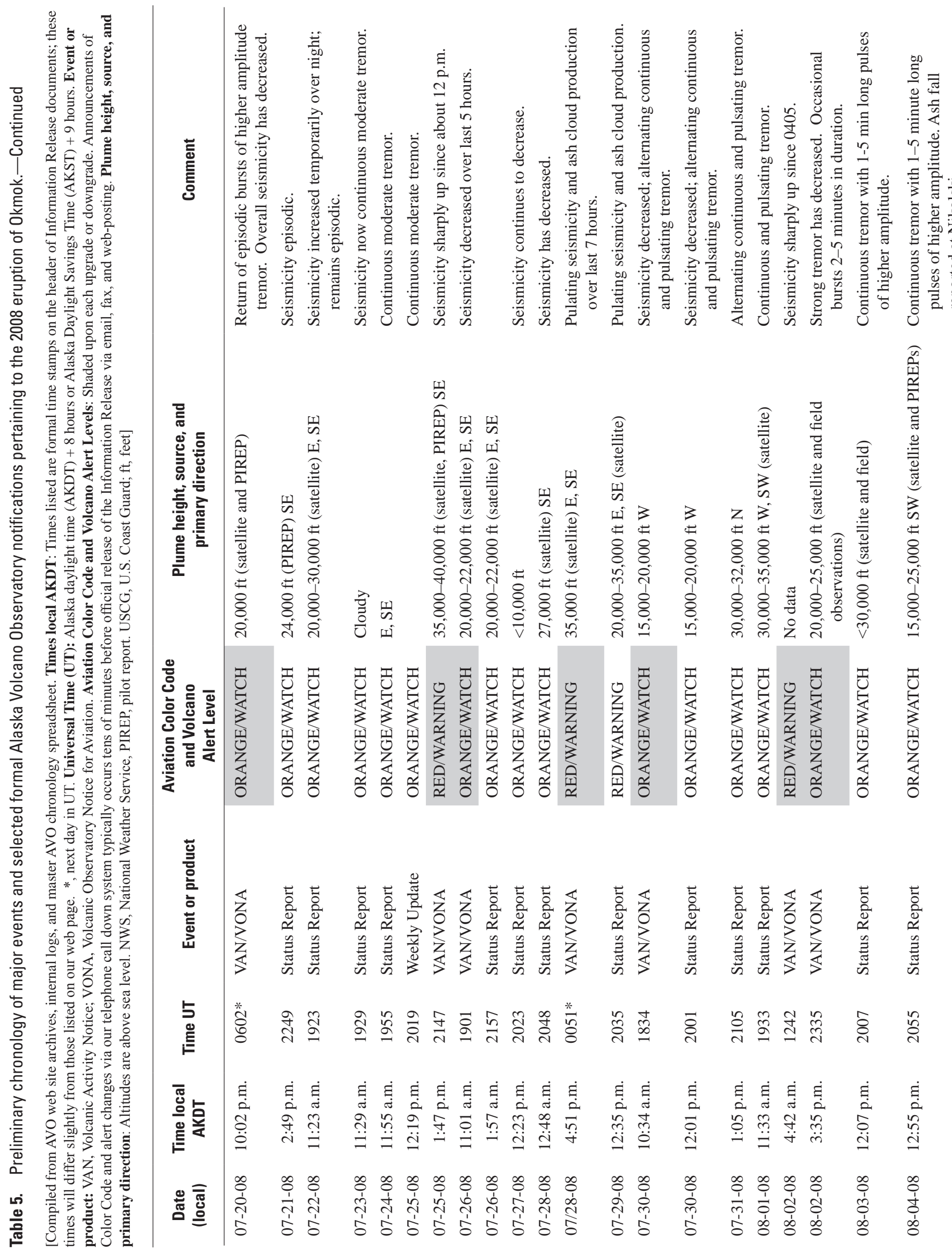


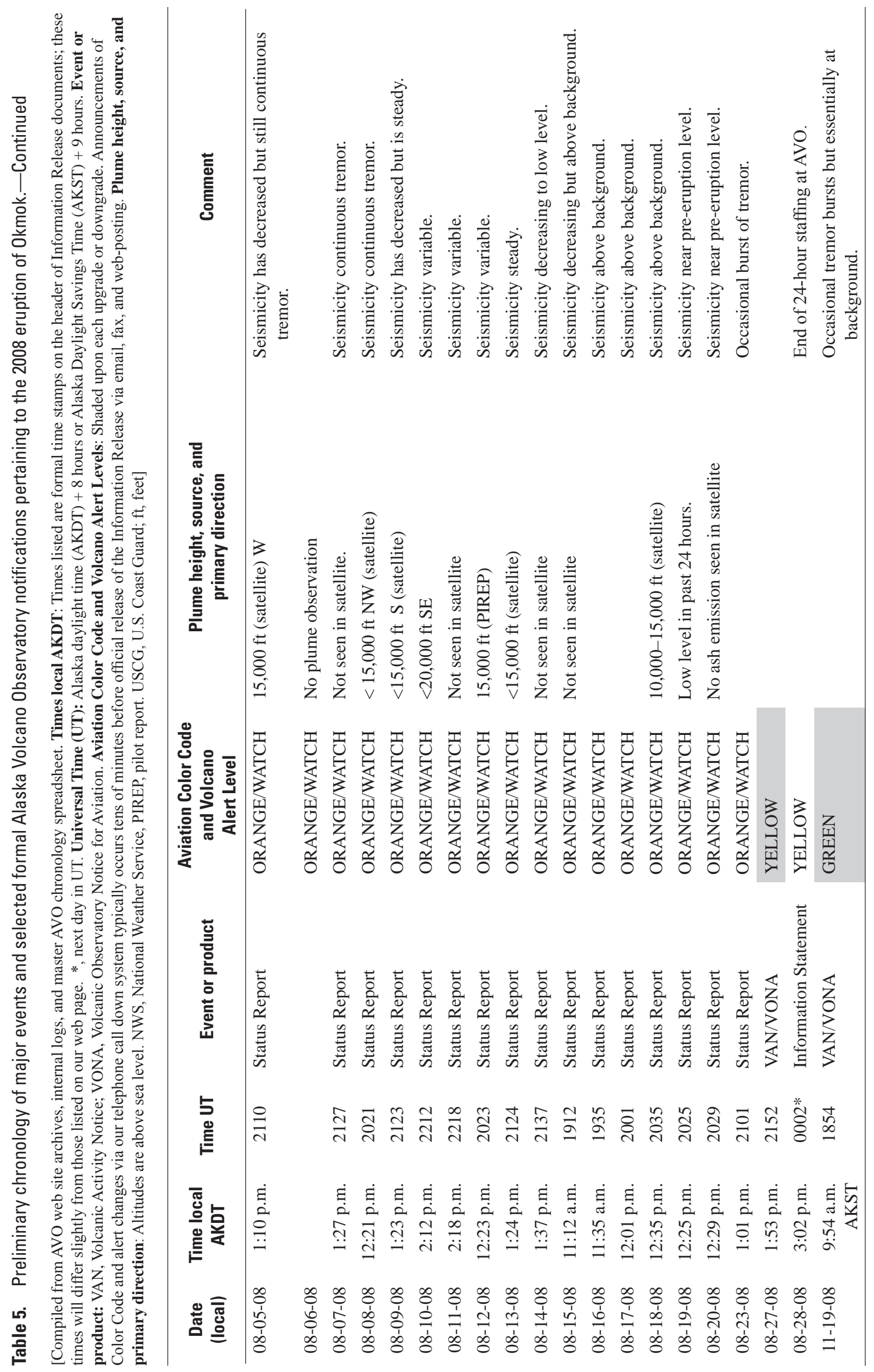




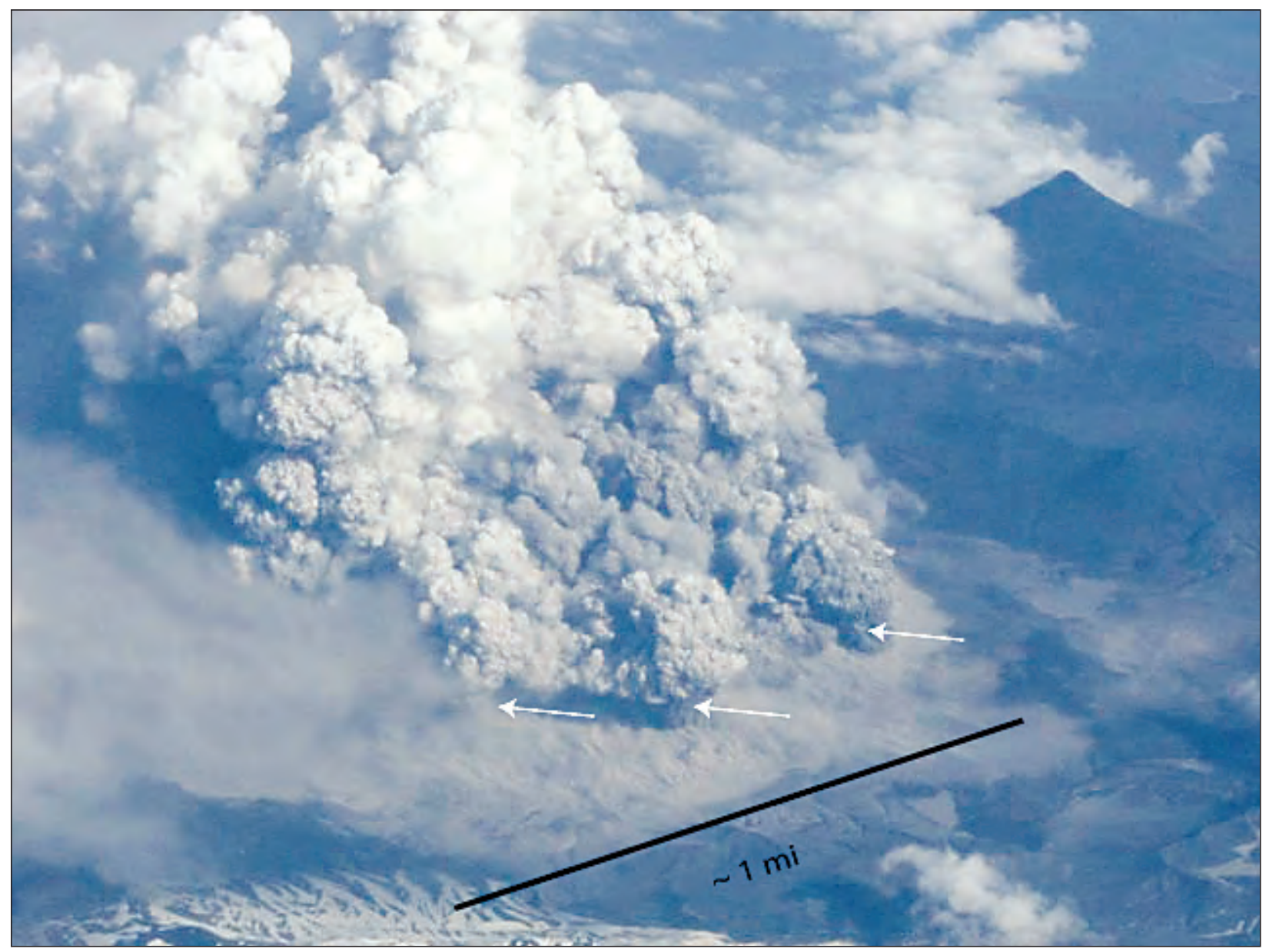

Figure 16. Okmok Caldera in eruption on July 20, 2008. Note the very broad base of the eruption column (using recognizable features as a guide, the width of the eruption column at the surface is about $1,600 \mathrm{~m}$ or about $1 \mathrm{mi}$ ), the indication of multiple point sources of ash and water vapor (arrows), and the variable ash content of the rising column. Photograph courtesy of Phil Walgren, Alaska Airlines. AVO database image URL: http://www.avo.alaska.edu/images/ image. $p h p ? i d=14436$.

Evacuated Fort Glenn ranch caretaker Lonnie Kennedy returned to the island on July 23 and, over the next several days, photographed eruption impacts and continuing ash emission and ash fall in the vicinity of the caldera. Kennedy documented ongoing muddy water flow across the lowlands surrounding the ranch; lahars in several drainages north of the ranch had been sufficiently energetic to destroy pre-existing wooden bridges and culverts and cause severe bank erosion. Dramatic new deltas had formed at the mouths of a number of creeks draining the northeast and southeast flanks of Okmok (fig. 17). The exact timing of lahar activity during the first days of the Okmok eruption is uncertain. It is also not clear if lahar formation was due to rain-remobilization of tephra, syn-eruptive condensation of water vapor entrained in the eruption cloud (W. Scott, USGS, written commun., 2008), dewatering of wet tephra fall, melting of snowpack, or some combination of these or other processes. Overbank deposits and the presence of large boulders atop the surface of the 2008 lahar fan at the mouth of Crater Creek (Crater Creek drains the caldera northwestward into the Bering Sea) suggest temporarily high discharge rates possibly caused by a sudden release of water from the caldera early in the eruption. 


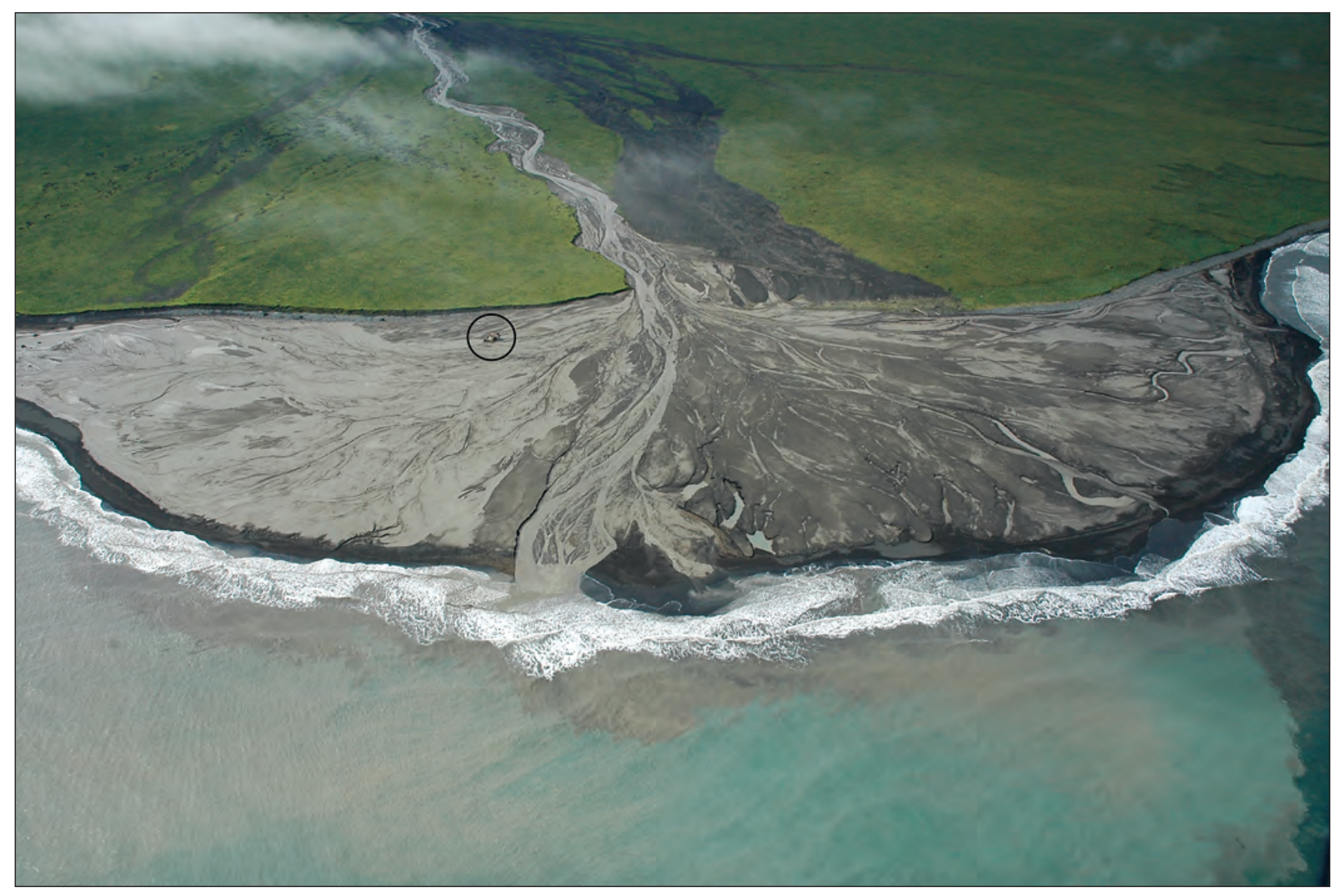

Figure 17. 2008 Crater Creek lahar deposit delta and sediment plume into the Bering Sea. Shipwreck visible near the pre-eruption shoreline bluff and left of the main central channel (circled) is $17 \mathrm{~m}(56 \mathrm{ft})$ long. Crater Creek drains the caldera through a notch in the caldera wall called "The Gates" and extends to the northeast into the Bering Sea. Photograph by C.A. Neal AVO/USGS,

September 11, 2008. AVO database image URL: http://www.avo.alaska.edu/images/image.php?id=15446.

Kennedy's aerial photographs of the caldera from August 1 show the upper Crater containing an active, braided channel of muddy water indicating some drainage from the caldera. The terrain immediately east of the caldera was thickly covered in light brown to gray tephra. Deep rills and dendritic drainage networks existed on most surfaces; at higher elevations, the pre-eruption snowpack was visible beneath the 2008 debris, and water flowed from the base of the snowpack in many places. A partially clear view into the caldera on August 1 showed ash and water-vapor-rich clouds boiling from at least two point sources on the northwest flank of Cone D and just to the west of Cone D (fig. 18). Dark collars of debris enclosed each locus of venting. The pre-eruption lake northeast of Cone $\mathrm{D}$ had been significantly modified: standing water covered a much smaller area and what had been the lake was now a surface of tephra and scattered ponds. 


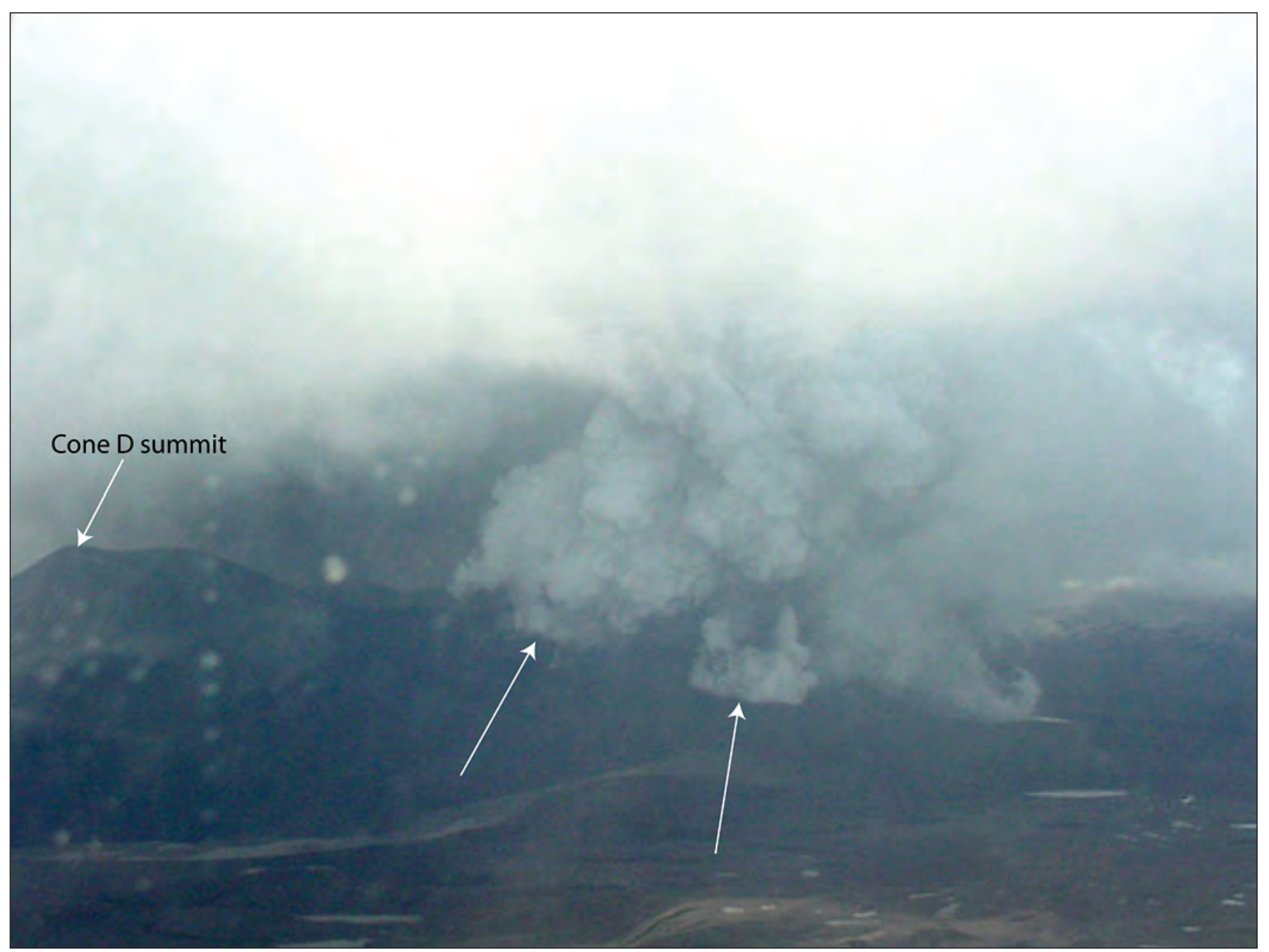

Figure 18. Active vents within 0 kmok Caldera on August 1, 2008. Arrows point to preexisting Cone $D$ summit and primary vents surrounded by collars of dark tephra. Photograph by L. Kennedy, used with permission. AVO database image URL: http://www.avo. alaska.edu/images/image.php?id=15666.

The first AVO crew on scene in late July was unable to land near the caldera due to active ash emission. They focused on documenting the extent and character of ash fall and lahar deposits outside the caldera, taking observations of the ongoing eruption, repairing a key data repeater site on Makushin Volcano on Unalaska Island, and collecting samples and eye-witness accounts. They obtained some close-up views into the caldera and also distant views of the eruption column from the Fort Glenn ranch. On August 2 and 3 , the eruption column had increased in intensity, height, and ash content (figs. 19 and 20). This change was coincident with an increase in amplitude of seismic tremor. AVO crew observations, photographs, and film footage during this time of heightened activity suggest a migration of the location of active venting on the caldera floor over the span of minutes. On overflights near the eruption site, the field crew observed a ground-hugging cloud of tan-colored ash covering the caldera floor and obscuring views of the immediate area. In glimpses of the caldera floor near the site of the pre-eruption lake near Cone D, they noted chaotic, disrupted terrain and channels of flowing water. 


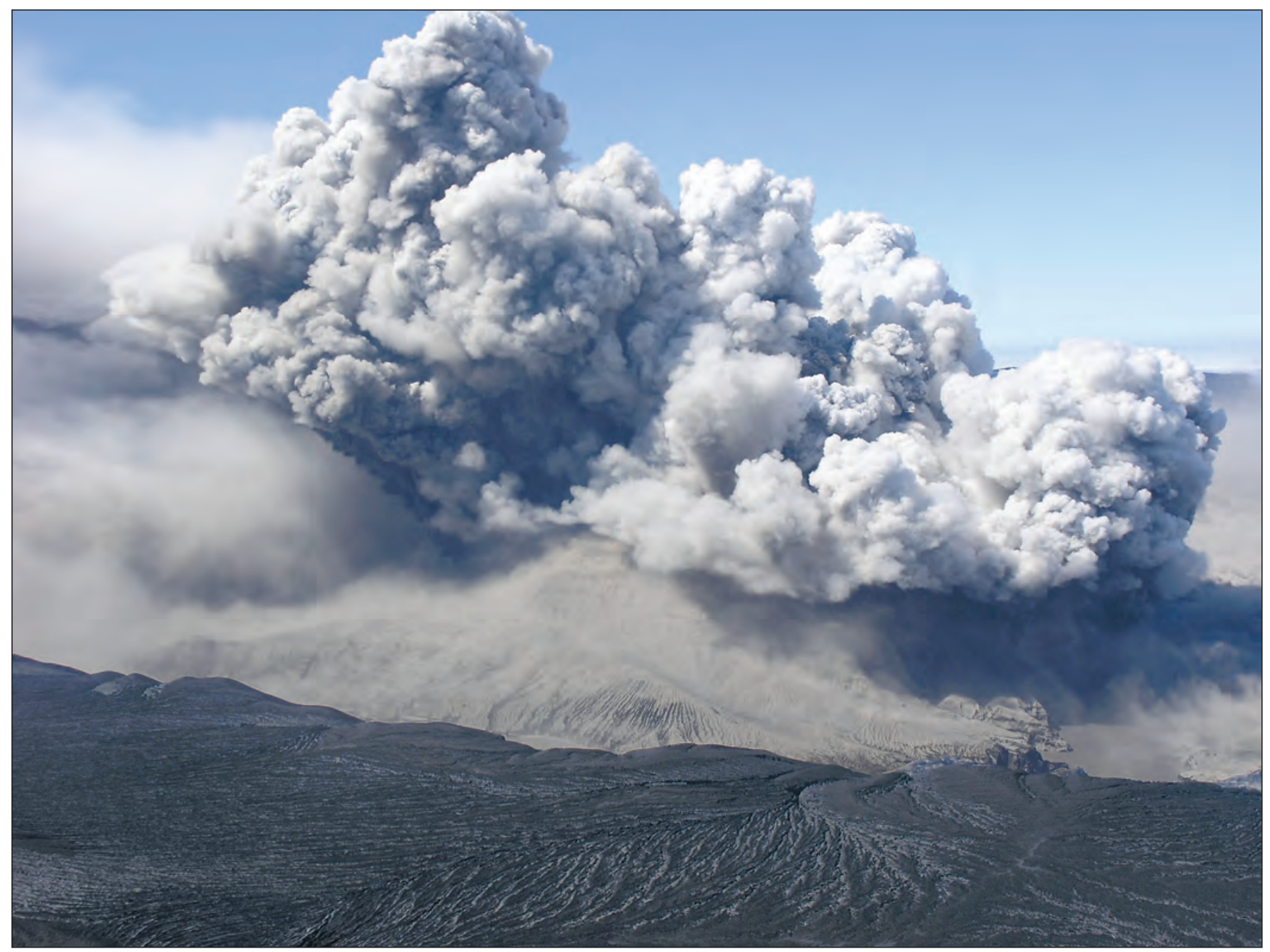

Figure 19. Okmok Volcano in eruption on August 2, 2008. View is toward the southwest from the caldera rim northeast of Cone D. New tephra deposits atop Cone D are light gray in color and deeply rilled in places. Standing water occurs at the base of Cone D (lower right) in the same area as the pre-eruption Cone D lake. Photograph by J. Schaefer, AVO/ADGGS. AVO database image URL: http://www.avo.alaska.edu/images/image.php?id=14700. 


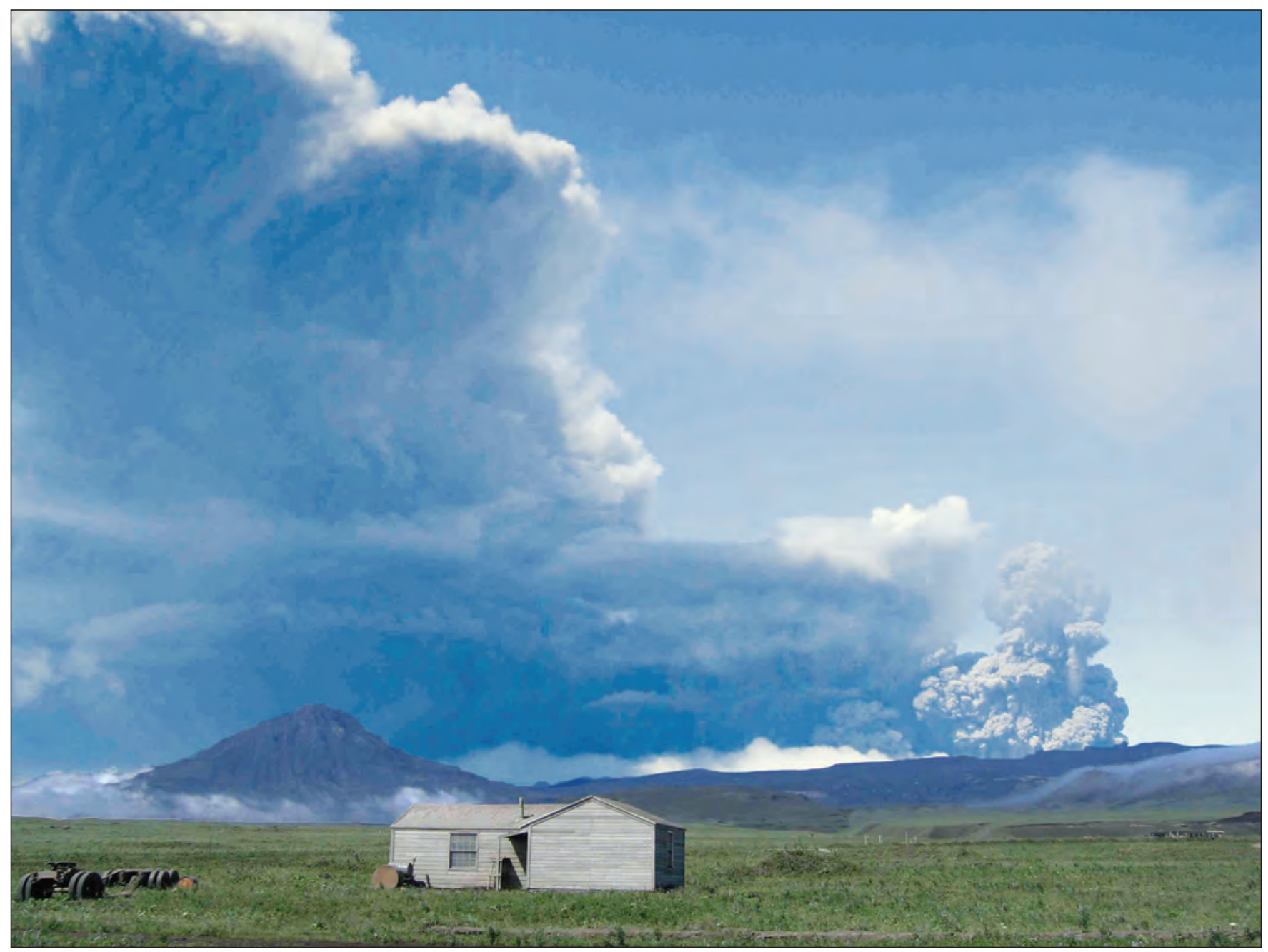

Figure 20. Okmok eruption plume as seen from Fort Glenn (ranch building in foreground) on August 3, 2008. The small peak to the left is Tulik, a Pleistocene extra-caldera stratocone (see fig. 14). Images taken from passing Alaska Airlines jets on the same day show a similar southwest-drifting eruption cloud that ascends in altitude as it travels downwind. Ash from this phase of the eruption ultimately reached the community of Nikolski on the west end of Umnak Island. Photograph by J. Larsen, AVO/UAFGI. AVO database image URL: http://www.avo.alaska.edu/images/image.php?id=14718. 
Due to the renewed intensity of the eruption, AVO elevated the Aviation Color Code and Volcano Alert Level again to RED/WARNING early on the morning of August 2 (table 5), and the caretaker and family at the Fort Glenn ranch decided to evacuate for the second time. During the last days of July and the first days of August, prevailing winds shifted to be out of the northeast.

Subsequently, over the first 2 weeks of August, eruption intensity and cloud height generally decreased and ash emission ceased altogether by August 19. A USGS helicopter crew working in the Aleutians entered the caldera on August 13 during the waning phase of eruption and photographed a single active vent enclosed within a steepsided tephra cone (figs. 21 and 22). Dark ash boiled out of the tephra cone surrounded by a collar of white water vapor; winds were from the northwest sending the ash and water vapor cloud over the summit of Cone D and the caldera rim. A significant lake was now present near the site of the preeruption lake and the landscape was completely covered with dark gray ash. The surface north of Cone D was pocked with craters several meters to several tens of meters in diameter. A series of scallop-margined basins and coalesced craters, some hosting standing water, extended in a line west of Cone D.

On August 23, about 1 week after the end of the eruption, Lonnie Kennedy again photographed the eastern caldera from the air. Although Crater Creek was open and flowing just inside the caldera, a through-going surface connection between Crater Creek and the growing lakes had not been established. Wind re-suspended a tan-colored ash in the vicinity of the largest of the new vents.

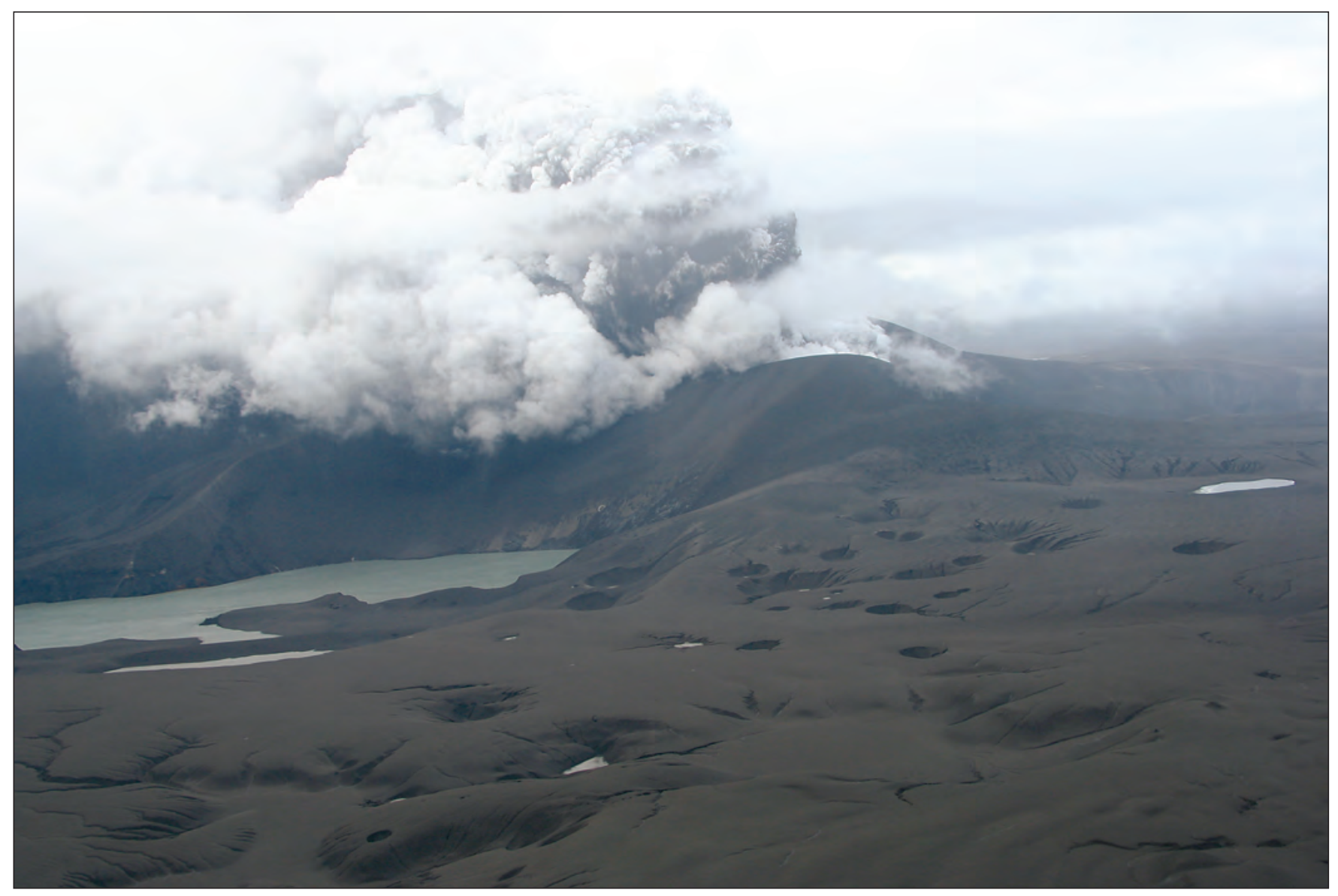

Figure 21. Eruption cloud at Okmok on August 13, 2008. Ash and water vapor billow from the new tephra cone vent inside $0 \mathrm{kmok}$ Caldera. A lake has reformed in the approximate location of the pre-eruption lake at the steep, truncated northeast base of Cone $\mathrm{D}$ (middle left). Note the smooth tephra surface pocked by circular collapse craters. Winds are from the northwest and taking the eruption cloud over the summit of Cone D, which is obscured. Photograph by C. Hults, USGS. AVO database image URL: http:// www.avo.alaska.edu/images/image.php?id=15120. 


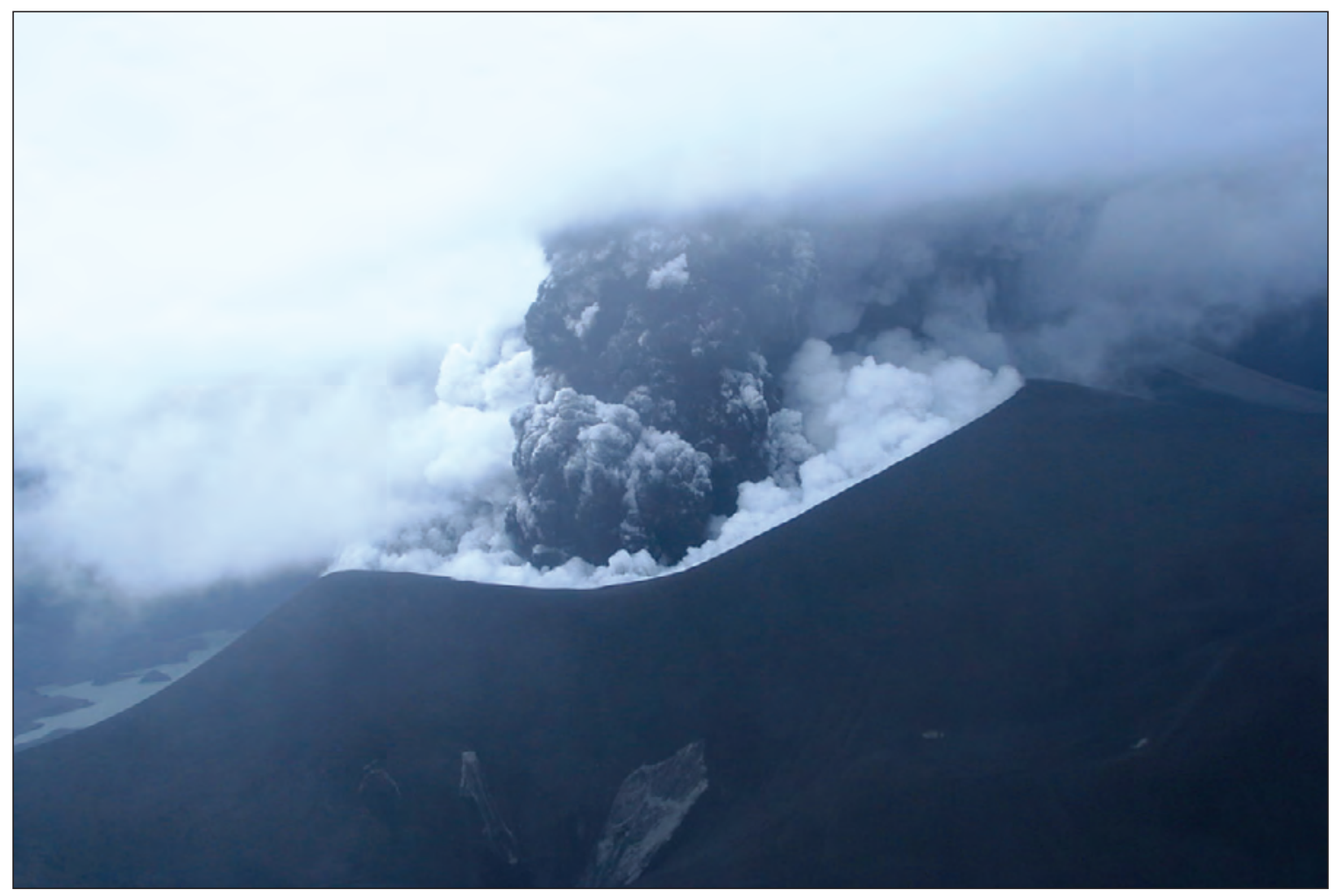

Figure 22. New tephra cone-approximately 100-200 m (330-660 ft) high-with a summit crater about 750$800 \mathrm{~m}(2,460-2,620 \mathrm{ft})$ in diameter-perched on the northeast flank of Cone $D$ (the summit of Cone $D$ is obscured by ash at upper right). Water has returned to the site of the pre-eruption Cone D lake, visible here in the distance at lower left. Light colored swatches on the flank of the tephra cone at lower center are surface slumps that expose drier tephra within the cone. Photographs by C. Hults, USGS, August 13, 2008. AVO database image URL: http://www.avo.alaska.edu/images/image.php?id=15119.

AVO's week-long September expedition to Okmok gathered reconnaissance information about the eruption deposits and impacts, repaired some seismic and GPS instruments, and deployed additional GPS recording stations (some of which were retrieved in the summer of 2009 by the Plate Boundary Observatory field crew). Most tephra sections excavated within and outside the caldera exposed planar to slightly wavy-bedded, fine-grained fall and surge deposits. Northeast of the vent region where tephra accumulation was thickest, the basal unit from the July 12 opening phase was a coarse ash-lapilli fall deposit; individual clasts were coated with a very fine ash (fig. 23). Evidence of significant water interaction throughout the 2008 tephra sequence includes (1) very high porosity of individual beds reflecting post-emplacement de-watering; (2) plastering texture on perpendicular surfaces facing the vent; (3) abundant accretionary lapilli; (4) overall fine-grained nature of the deposit. Outside the caldera, excavated sections contained mostly fall deposits with thin and discontinuous aeolian horizons; no clear evidence for energetic, far-traveled, extra-caldera surges was noted.

Field observations in September combined with analysis of photographs and satellite images indicate that the eruption occurred from a series of vents that opened during the first 2 weeks of the eruption. These vents extended in a roughly linear zone about $2 \mathrm{~km}$ (1.2 mi) long across the caldera floor (figs. 24 and 25). One crater formed next to, and eventually captured and drained, the pre-existing lake northeast of Cone D. A tephra cone ('New Cone') had been constructed atop the longest-lived 2008 vent (fig. 26). By mid-September, the explosion and collapse craters to the west of Cone D had filled with water and formed a new lake ('New Lake') about $0.6 \mathrm{~km}^{2}$ $\left(0.2 \mathrm{mi}^{2}\right)$ in area (figs. 24 and $\left.\underline{25}\right)$. 


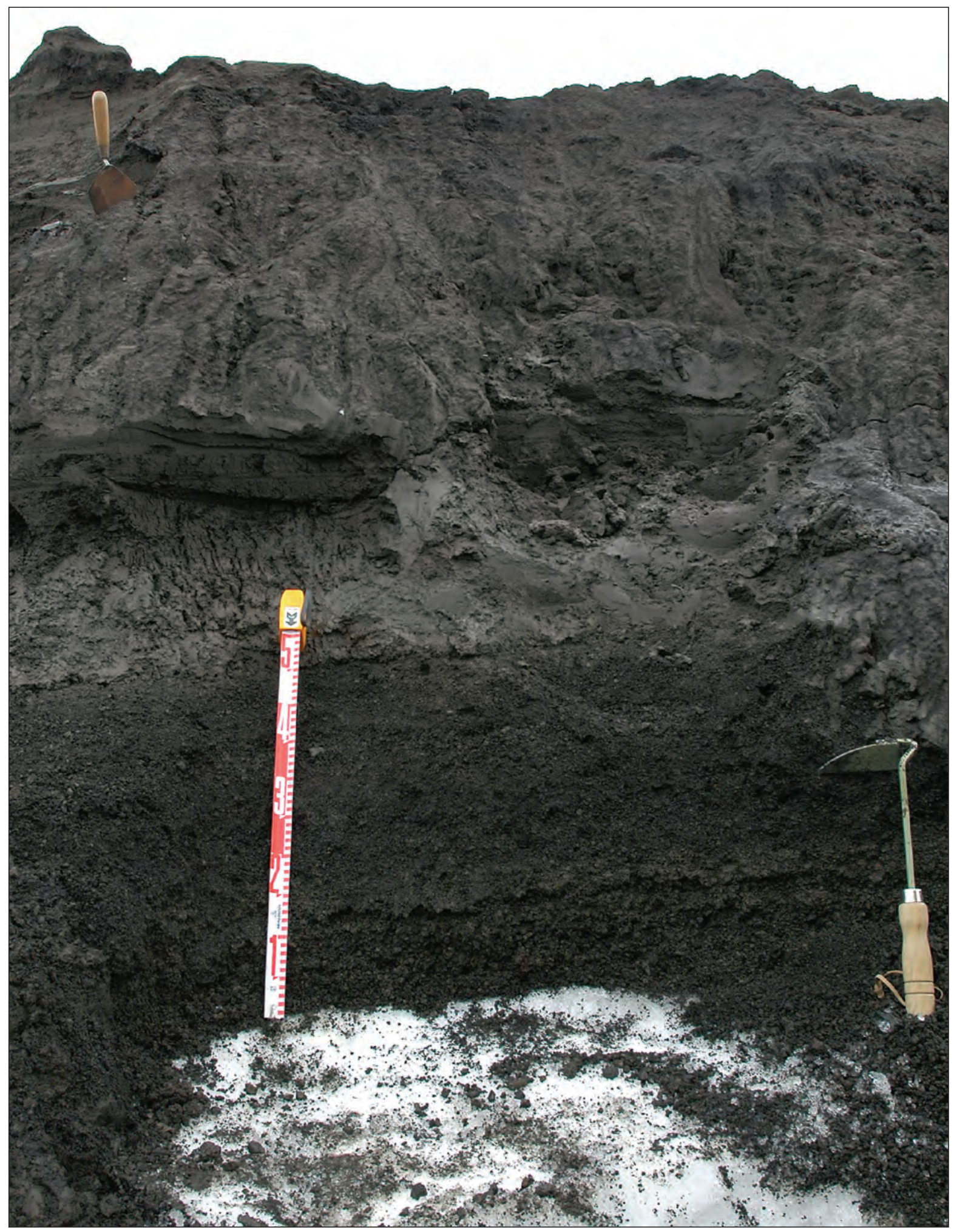

Figure 23. Stratigraphic section JFLOK016 on the northeast rim of Okmok Caldera. The pre-eruption snowpack below was up to $4 \mathrm{~m}$ (13 ft) thick. The 50 -cm-thick, (20 in.) dark, coarse deposit at base is mostly lapilli-tephra fall from the July 12 opening phase of the eruption; the two distinct coarse units within this deposit both fine upward and are separated by a finer, ash-rich horizon [visible here as a lighter colored ledge about $15 \mathrm{~cm}$ ( 6 in.) above the base.] Approximately the upper $1.5 \mathrm{~m} \mathrm{(60} \mathrm{in.)} \mathrm{of} \mathrm{the} \mathrm{deposit} \mathrm{consists} \mathrm{here} \mathrm{primarily}$ of saturated, muddy, gray, planar fine sand and silt beds several millimeters to several centimeters thick. Faint, discontinuous laminae of light brown ash, possibly aeolian in origin, also are present. Tape measure displays $50 \mathrm{~cm}$ (20 in.). Photograph by C.A. Neal AVO/USGS, September 9, 2008. AVO database image URL: http://www.avo.alaska.edu/images/image.php?id=31902. 


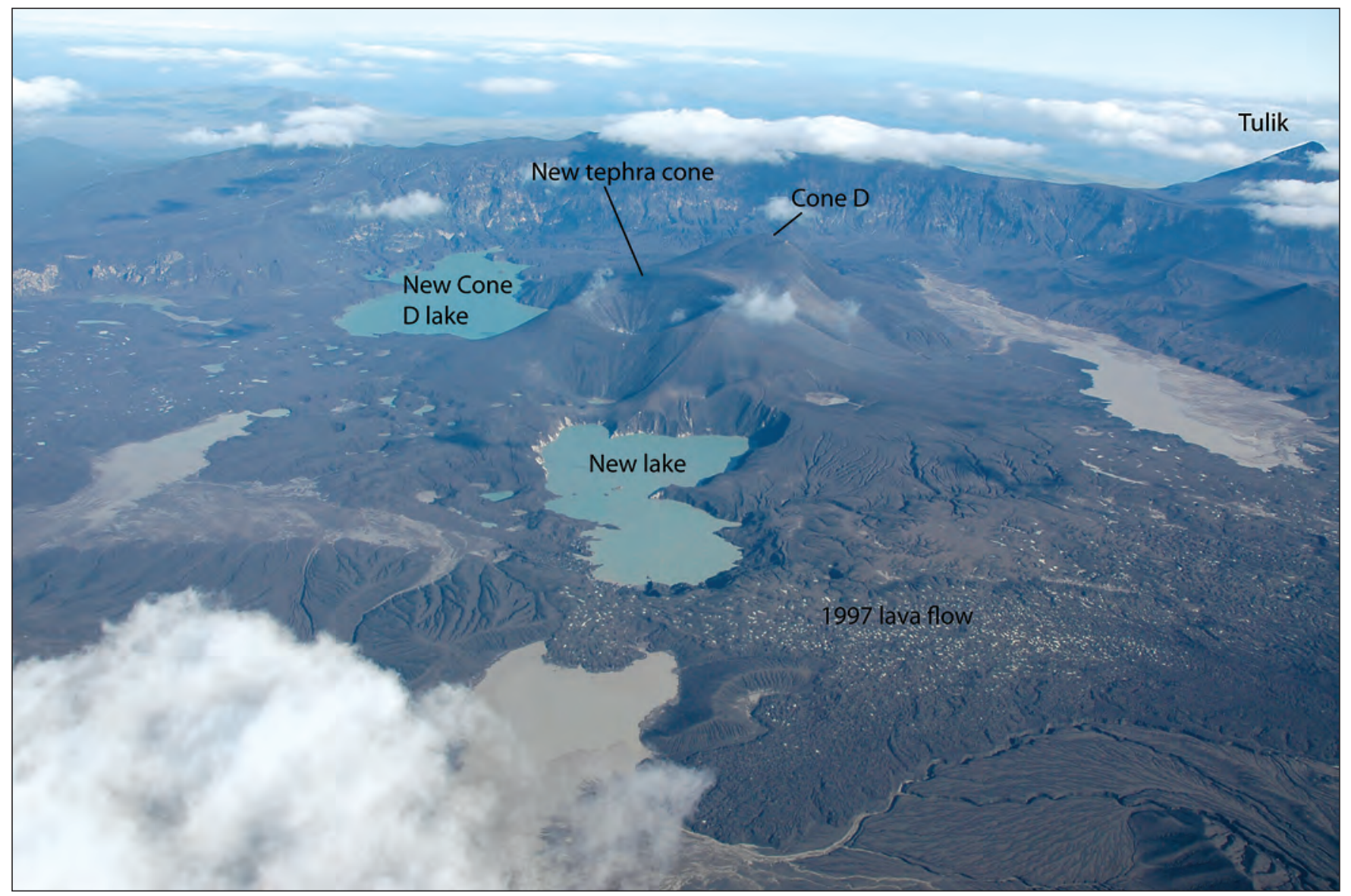

Figure 24. Post-eruption oblique aerial view to the southeast across the caldera. Note new tephra cone with circular crater on the north flank of Cone D, and a new lake (milky blue in foreground). This lake formed by coalescence of accumulating water in a series of craters formed by explosion, venting, and collapse during the eruption. The milky blue lake in the distance formed at the approximate location of pre-eruption Cone D lake; near the base of Cone D, several discolored thermal upwelling zones were present in mid-September. Note speckled appearance of the 1997 lava flow due to small, water-filled depressions in the tephra pile atop the rugged lava surface. Tan lakes at bottom, upper right, and middle left are shallower bodies of water impounded by tephra. The overall gradient of the caldera floor - and presumably the groundwater table-slopes downward from lower right to upper left. Photograph by C.A. Neal AVO/USGS, September 15, 2008. AV0 database image URL: http://www.avo.alaska.edu/images/image. php?id=15480. 


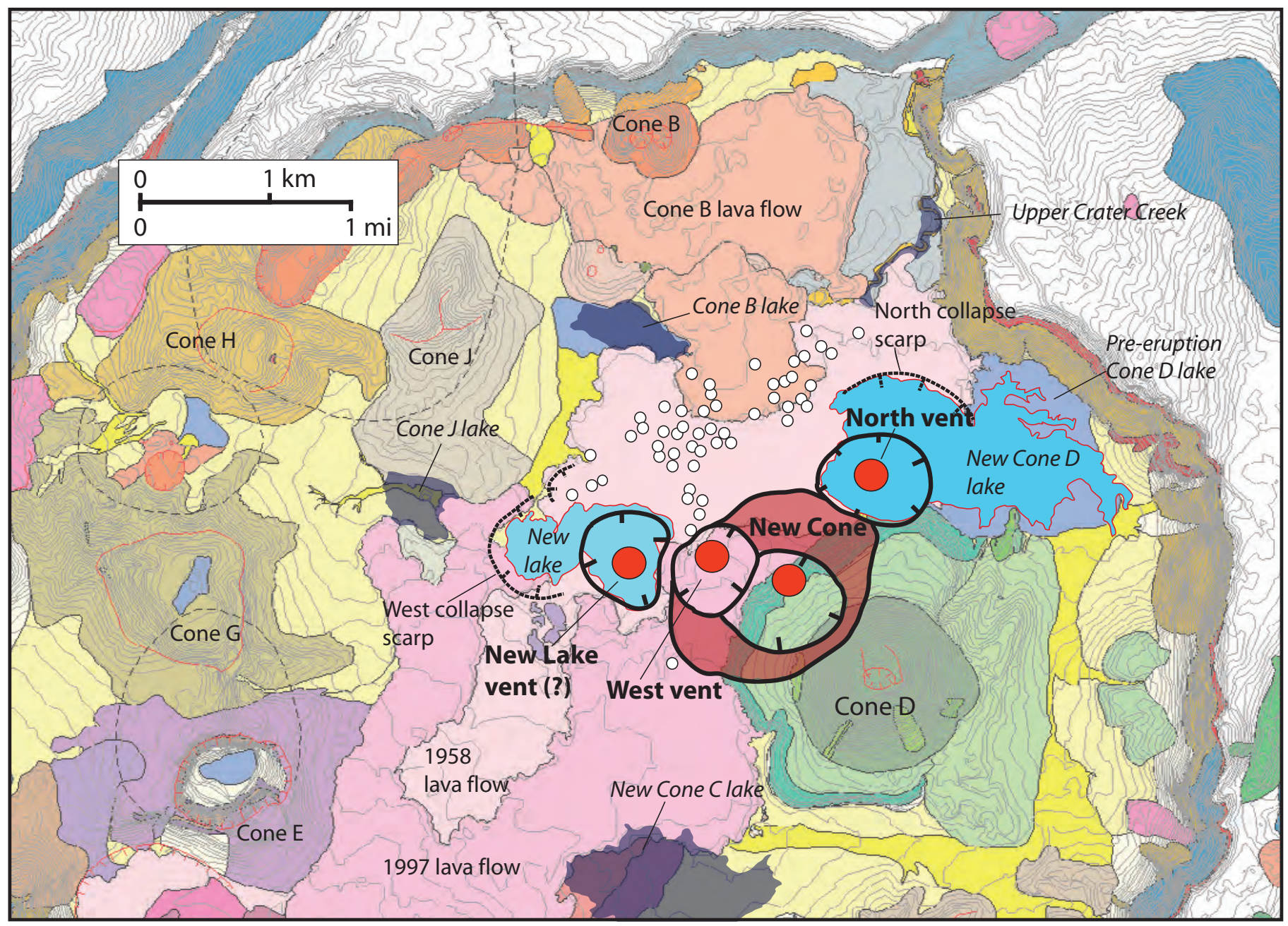

Figure 25. Principle features of the 2008 eruption atop topography and a geologic map of part of the 0 kmok caldera. Primary 2008 vent locations are shown by red dots. Not all vents were active at the same time or for the entire eruption; the main and longest-lived vent is shown as the "New Cone." Dark hachured lines show primary crater forms; dashed hachured lines are collapse scarps. White dots are collapse craters noted in September 2008 (see fig. 27). The two prominent new lakes are shown in light blue. Four dark gray shaded areas are other standing bodies of water that may be ephemeral due to impoundment by tephra dams. 


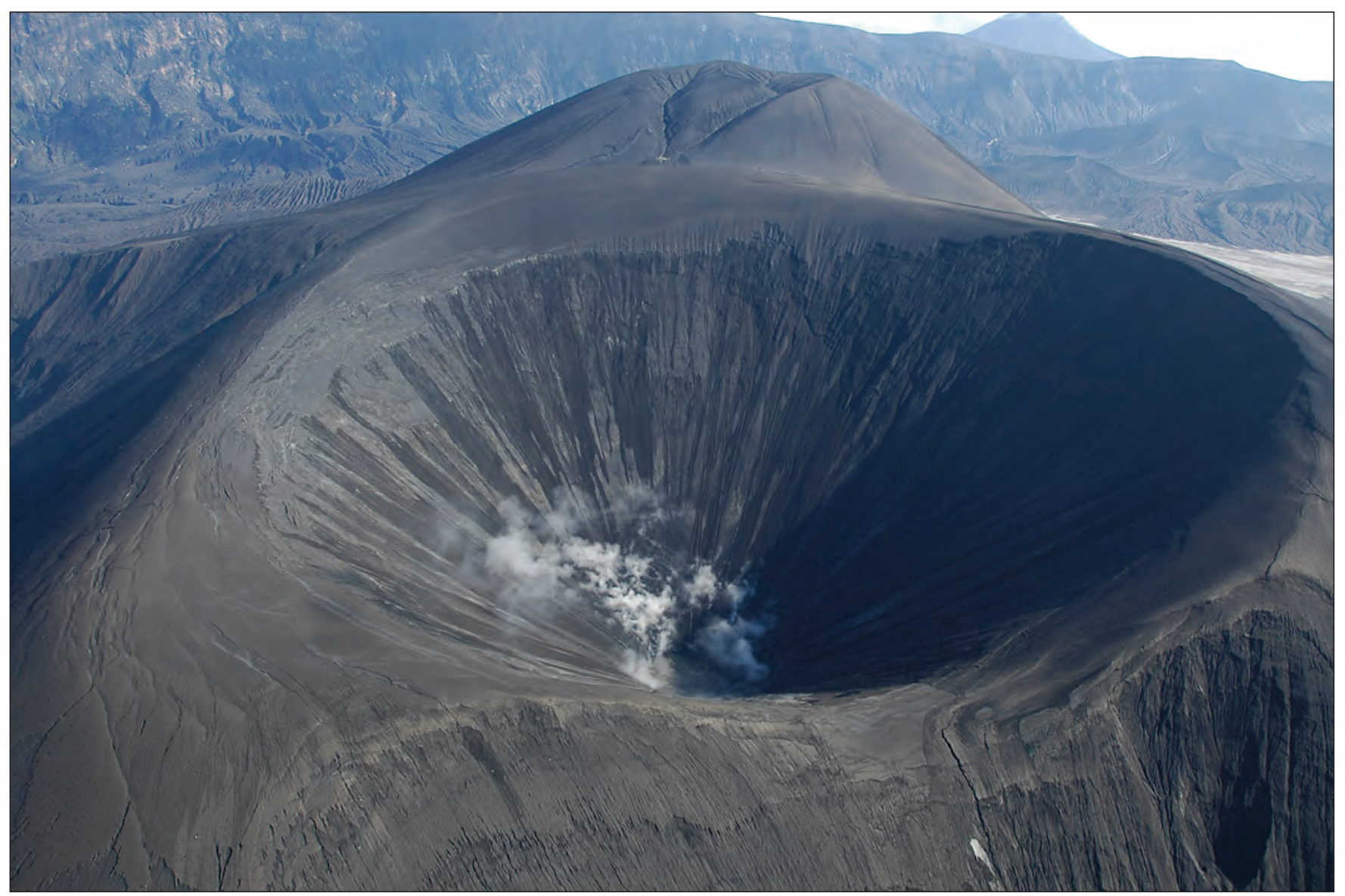

Figure 26. New tephra cone formed over the longest-lived vent of the 2008 eruption. The summit of Cone D, mantled thickly by debris, is just beyond. Mount Tulik is in the far distance outside the caldera rim. The summit of the new cone rises more than 200 $\mathrm{m}(660 \mathrm{ft})$ above the old lake level out of the photograph to the left. The summit crater of the new cone is about about $750-800 \mathrm{~m}$ $(2,460-2,620 \mathrm{ft})$ across from rim to rim. The bottom of the crater was actively filling with fine debris moving down the very steep crater walls. Gray, lithic, ballistic blocks up to $1 \mathrm{~m}(3.3 \mathrm{ft}$ ) across (all those sampled were old, dense lavas) littered the tephra cone rim and were visible on the crater floor. Steaming from the crater floor generally was diffuse with a few more strongly steaming jets; a faint odor of hydrogen sulfide was noted when close to the rim. Photograph by C.A. Neal, AVO/USGS, September 15, 2008. AVO database image URL: http://www.avo.alaska.edu/images/image.php?id=15476. 


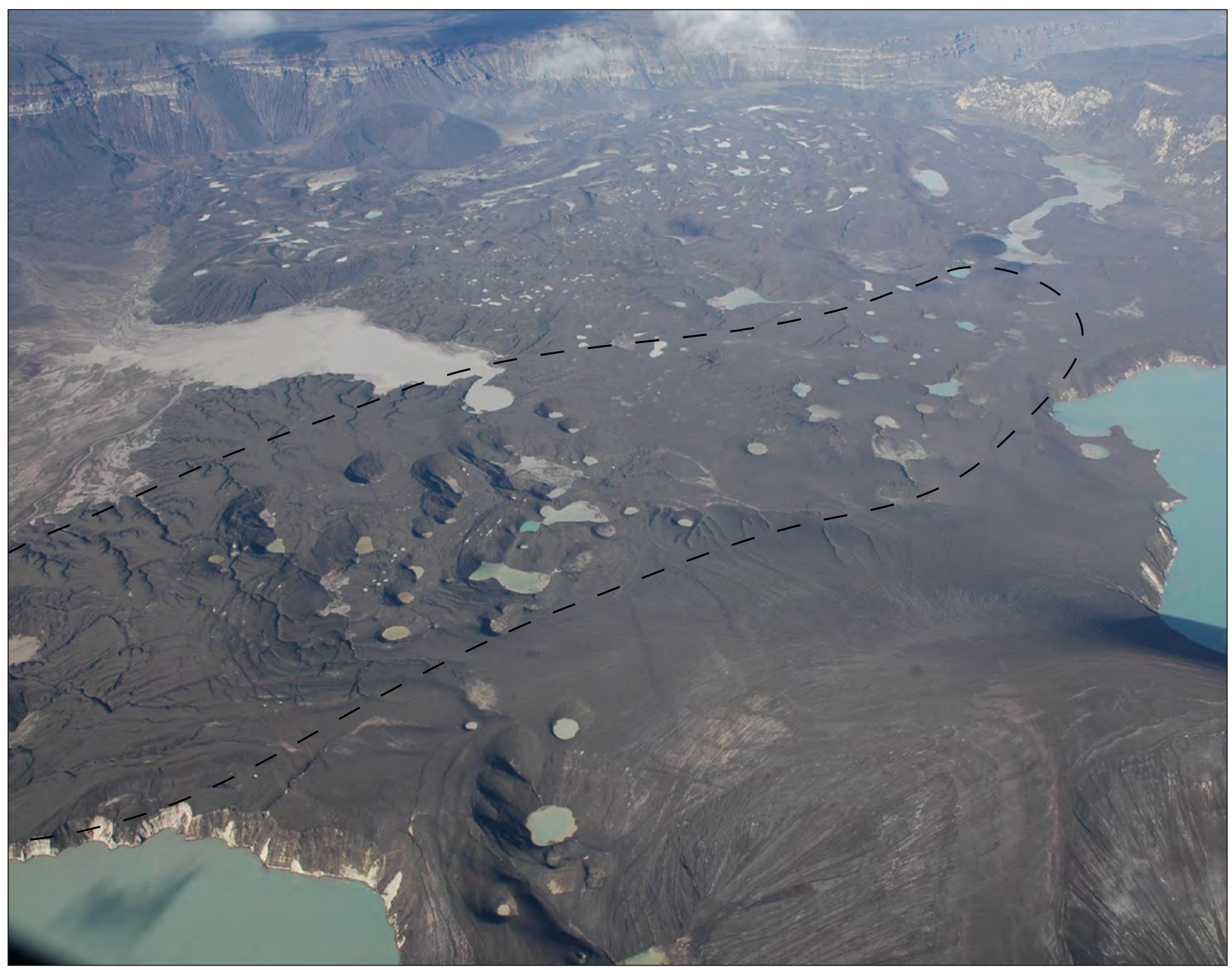

Figure 27. Collapse pits (circled area) in a zone extending southwest-northeast of Cone D. The new tephra cone and crater complex are at lower right. Modified Cone D lake at right and new lake also contained within 2008 vent forms at lower left. Small depressions containing water at the very top of the photograph are perched atop the Cone B (erupted in 1817) lava flow surface now thickly mantled by 2008 tephra. Photograph by C.A. Neal, AVO/USGS September 15, 2008. AVO database image URL: http://www.avo.alaska.edu/images/ image. $p h p ? i d=15483$.

Eruptive products from the 2008 sequence are basaltic andesite in composition, slightly more silicic than the range of Okmok chemistry represented by other post-caldera (last about 2,000 years BP) eruptions (Larsen and others, 2009). The finegrained nature of most 2008 tephra and the lack of an effusive phase pose a challenge to understanding changes in eruption chemistry with time. Coarse juvenile lapilli from the opening phase of the 2008 eruption were collected on the caldera rim just above the outlet of Crater Creek in a notch through the caldera wall informally called "The Gates" (ig. 14); this location was near the main northeast axis of deposition. Clast types in the July 12 opening tephra range from dense to vesicular scoria and pumice, and crystal fragments (Mariah Tilman, AVO/UAFGI, written commun., 2008). Some dense clasts may represent accidental lithics incorporated during the opening explosions through the caldera floor and lava flows of Cone D. Larger frothy pumiceous clasts were found along the shoreline of one of the shallow lakes within the caldera; because they are not in place, they cannot be confidently assigned to the 2008 event, but they were fresh-looking, fragile, and most likely represent material erupted on July 12. These clasts are up to 5-10 cm (2-4 in.) across and are light to dark brown, vesicular, scoriaceous pumice with irregular, fractured chill rinds.

Following cessation of eruption in mid-August, seismicity remained relatively low with occasional bursts of higher amplitude tremor. AVO downgraded the Aviation Color Code and Volcano Alert Level to YELLOW/ADVISORY on August 27 (table 5) after a week with no ash clouds discerned in satellite images. Occasional thermal anomalies were visible by satellite and are likely attributable to the still-warm vent 
area, fumaroles, and/or lakes within the caldera. By midNovember, after 3 months of steadily decreasing seismicity, AVO changed the Aviation Color Code to GREEN and Volcanic Alert Level to NORMAL. In the accompanying remarks, AVO indicated that despite the cessation of eruptive activity, hazardous conditions persisted. Unstable, muddy surfaces and slopes of new volcanic debris within the caldera could collapse at any time. New and rapidly changing lakes, ponds, and multiple steep-walled craters through the new tephra blanket would present a hazard to anyone visiting the caldera. Magmatic gases and areas of high temperature could persist around the new tephra cone. All drainages leading downslope from the rim of the caldera are susceptible to remobilization of ash and other loose debris during heavy rains and spring melt. The Crater Creek drainage on the north-northeast flank of Okmok was considered especially vulnerable to sudden flooding events if tephra dams within the caldera were to fail suddenly and release impounded water.

AVO maintained 24-hour staffing from July 12 through August 28. Over the course of the eruption, AVO issued 17 Volcanic Activity Notices and two Information Statements (table 5).

Eruption impacts were modest except for the significant disruption to the ranch caretaker family on Umnak Island who evacuated twice from the island including the first time under great duress during the most energetic phase at the start of the eruption. Primitive roads on the east and south flanks of the caldera were cut by lahars and water floods and rendered at least temporarily impassable. Ash accumulation suppressed grass growth that resulted in diminished over-winter feed for the livestock that roam the island. According to the Kennedy family, it is possible that an increased number of cattle perished in the winter of 2008-09 because of this (Susan Kennedy, written commun., 2009). The island also hosts a large number of caribou, although we are unaware of any systematic population counts to gauge the impacts of the eruption. Offshore Umnak Island, volcanic sediment delivered to the coastline built significant new lahar deltas and fishermen reported dramatic changes to bottom conditions in the weeks after the eruption (Lonnie Kennedy, oral commun., 2008) Several boats received minor to trace ash fall with no ill-effects reported other than a single collapsed air filter (Dustin Dickerson, oral commun., 2008). Out of concern for the effects of ash fall, the U.S.Coast Guard closed Umnak Pass for several days in the immediate aftermath of July 12.

Over the course of the eruption, trace amounts of ash fell on several occasions in Unalaska-Dutch Harbor $120 \mathrm{~km}$ (75 mi) northeast of the volcano. The airport closed briefly to allow for clean-up of the runway and taxi ways. Cannery workers and other residents were concerned about impacts of the ash fall, however slight, on their health, and AVO worked with local health care providers and cannery management, and with the Alaska Department of Environmental Conservation Air Quality Division to issue health related information. AVO and UAFGI staff installed a 3 stage DRUM impactor air sampler in Unalaska to sample volcanic particulate from the ash fall events (Peter Rinkleff, AVO/UAFGI, written commun., 2008). AVO staff also traveled to Unalaska in late July to meet with the local Director of Public Safety, the resident Department of Environmental Conservation employee, U.S. Coast Guard Station Chief, Native Health clinic supervisor, cannery management, contract weather observer, and airport supervisor and maintenance manager about their concerns and accounts of the eruption. AVO staff participated in local radio interviews, gave a public lecture on the eruption, and met with members of the community to gather eyewitness accounts and answer questions.

AVO received both ash and pumice samples from citizens in Unalaska. By July 24, some Unalaska residents reported pea to gravel sized light to dark brown pumice washing ashore on several beaches in Unalaska; based on the timing and physical characteristics of the clasts, it is possible that these represented marine transported pumice from the July 12 eruption onset. Whether pumice of this size fell at sea or was washed into the sea by lahars or other flowage processes on Umnak is unknown.

Flights across the North Pacific were impacted for a period of several days in mid-July as the July 12 eruption cloud drifted north and east over the Gulf of Alaska. During the week following the eruption, aircraft over the lower 48 States observed and photographed the remnant of the Okmok aerosol cloud as it transited across North America at elevations in excess of 30,000 ft $(9,100 \mathrm{~m})$ ASL. NWS maintained a nearly constant SIGMET for the area impacted by ongoing ash production during the event; SIGMET boundaries were modified over time on the basis of pilot reports of ash cloud drift as well as satellite images showing the cloud combined with forecast motion.

Okmok Volcano is a 10-km-wide (6.2-mi) caldera that occupies most of the eastern end of Umnak Island, located $120 \mathrm{~km}$ (75 mi) southwest of the important fishing and transportation hub of Unalaska/Dutch Harbor in the eastern Aleutian Islands. Okmok has had several eruptions in historic time typically consisting of ash emissions occasionally over $9 \mathrm{~km}(30,000 \mathrm{ft})$ ASL but generally much lower; lava flows crossed the caldera floor in 1945, 1958, and 1997 (Beget and others, 2005). The nearest settlement is Nikolski, population 27 , located $72 \mathrm{~km}$ (45 mi) west of the volcano (Alaska Department of Commerce, Communicty and Economic Development, written commun., 2010). A ranch caretaker family lives at Fort Glenn on the flank of the volcano about $10 \mathrm{~km}$ (6.2 mi) east of the caldera rim. Prior to 2008, AVO had installed an extensive real-time seismic and deformation monitoring network at Okmok. Eight short period and four broadband seismometers and four continuous GPS stations were distributed about the caldera; at the time of the 2008 eruption, only three GPS stations were operational (Larsen and others, 2009). The eruption destroyed one permanent broadband seismometer and GPS station and damaged at least three other instrument sites; several were resurrected during the September 2008 field campaign (M. Kaufman, AVO/ UAFGI, written commun., November 2009). 


\section{Cleveland Volcano}

CAVW\# 1101-24-

$52^{\circ} 49^{\prime} \mathrm{N} 169^{\circ} 57^{\prime} \mathrm{W}$

$1,730 \mathrm{~m}(5,676 \mathrm{ft})$

Chuginadak Island, east-central Aleutian Islands

INTERMITTENT EXPLOSIONS; ACTIVITY INTENSIFIES IN LATE JULY

Ash clouds, thermal anomalies, ash fall and ballistics on island, flowage deposits reach the sea.

Cleveland volcano on remote Chuginadak Island in the central Aleutians (fig. 1) continued to produce infrequent but sudden explosions of ash in 2008 with a brief period of more vigorous activity in late July. Cleveland is unmonitored by ground-based seismic instrumentation. A web camera $73 \mathrm{~km}$ (45 mi) east in the community of Nikolski on Umnak Island is often obscured by weather. In an area of frequent thick cloud cover, satellite remote sensing is limited in application to reliably detect thermal anomalies and ash clouds resulting from volcanic explosions.

Cleveland volcano began 2008 at Aviation Color Code YELLOW and Volcano Alert Level ADVISORY. Daily satellite monitoring detected an ash cloud drifting north from Cleveland in imagery on January 17; the cloud rose less than about $3 \mathrm{~km}(10,000 \mathrm{ft})$ ASL and it was visible in satellite imagery for 2 hours before dissipating. A weak thermal anomaly (TA) persisted in the summit area following this event, visible to analysts in rare, clear satellite images over the next few weeks. Another low-level (below about $1.5 \mathrm{~km}$ or 5,000 ft ASL) ash cloud was visible in a satellite image on February 8. Later that day, two pilot reports of volcanic ash from Cleveland reaching altitudes of 20,000 ft (6,100 m) ASL, confirmed on satellite imagery, prompted AVO to elevate the volcano to ORANGE/WATCH. With the exception of a weak, possible TA several days later, no further activity was detected and Cleveland was returned to YELLOW/

\section{ADVISORY status on February 12.}

Minor, short-lived ash explosions continued through the winter and were caught by the twice-daily routine satellite monitoring by AVO analysts or pilots on February 16, February 22, February 29, and March 4. Weak TAs seen in satellite imagery often followed these ash bursts; TAs continued to be spotted into the spring. ASTER satellite data in mid-April indicated intermittent low level activity producing ejecta and flowage deposits of very limited extent (fig. 28).

In late April and early May, the TA at Cleveland became more persistent. On May 7, an ash cloud was detected in satellite imagery and AVO received a report from the F/V
Raven Bay of a dusting of ash north of the community of Nikolski. Satellite imagery detected impact craters in snow near the summit of the volcano, consistent with an explosive event. A weak TA was detected on June 8.

No further reports of activity were received until July 21 when fishing vessels reported an explosive eruption of Cleveland about 12 p.m. Several mariners documented activity with photographs and video (figs. 29, $\underline{30}$, and $\underline{31}$ ). The ash cloud was described as moving generally northwest from the volcano but the cloud was not visible in satellite imagery, perhaps due to thick regional cloud cover. AVO declared ORANGE/WATCH based on these reports. Subsequently, pilots reported the Cleveland ash plume to be between 15,000 and 17,000 ft ASL and moving southeast from Cleveland. An AVO scientist aloft over Okmok in a USCG C-130 also observed the Cleveland ash cloud—distinctly darker than the regional meteorological clouds-approaching from the west.

On July 22, satellite imagery showed a greater than $50 \mathrm{~km}$ (31 mi) long plume of gas and water vapor with some ash drifting east and southeast at an altitude of between 3 and $6 \mathrm{~km}$ (10,000 and 20,000 ft). A strong and persistent TA may have reflected the presence of a lava flow in the summit crater and along the upper steep portion of the volcano. A fairly continuous, weak ash plume continued at least through July 25. On July 27, satellite images showed a possible ash cloud drifting southeast with a cloud top of less than $6 \mathrm{~km}$ $(20,000 \mathrm{ft})$. The strong TA near the summit of the volcano decreased in intensity during the first week of August and on August 6, AVO downgraded Cleveland to YELLOW/ ADVISORY.

On August 11, AVO reinstated ORANGE/WATCH because of the persistent TA interpreted to reflect effusion of lava from the summit crater. An August 12 satellite image showed a small ash cloud rising to about $25,000 \mathrm{ft}(7,600 \mathrm{~m})$ ASL and drifting southwest about $60 \mathrm{mi}(100 \mathrm{~km})$ before dissipating. Despite an intermittent thermal anomaly, AVO detected no further ash emissions and downgraded the volcano to YELLOW/ADVISORY on August 25 and to UNASSIGNED on October 9. (Note: in prior year reports, AVO has used the term 'Not Assigned' for this status). 


\section{Cleveland Volcano \\ ASTER daytime VNIR - 24 April 2008 - 22:29:31 UTC}

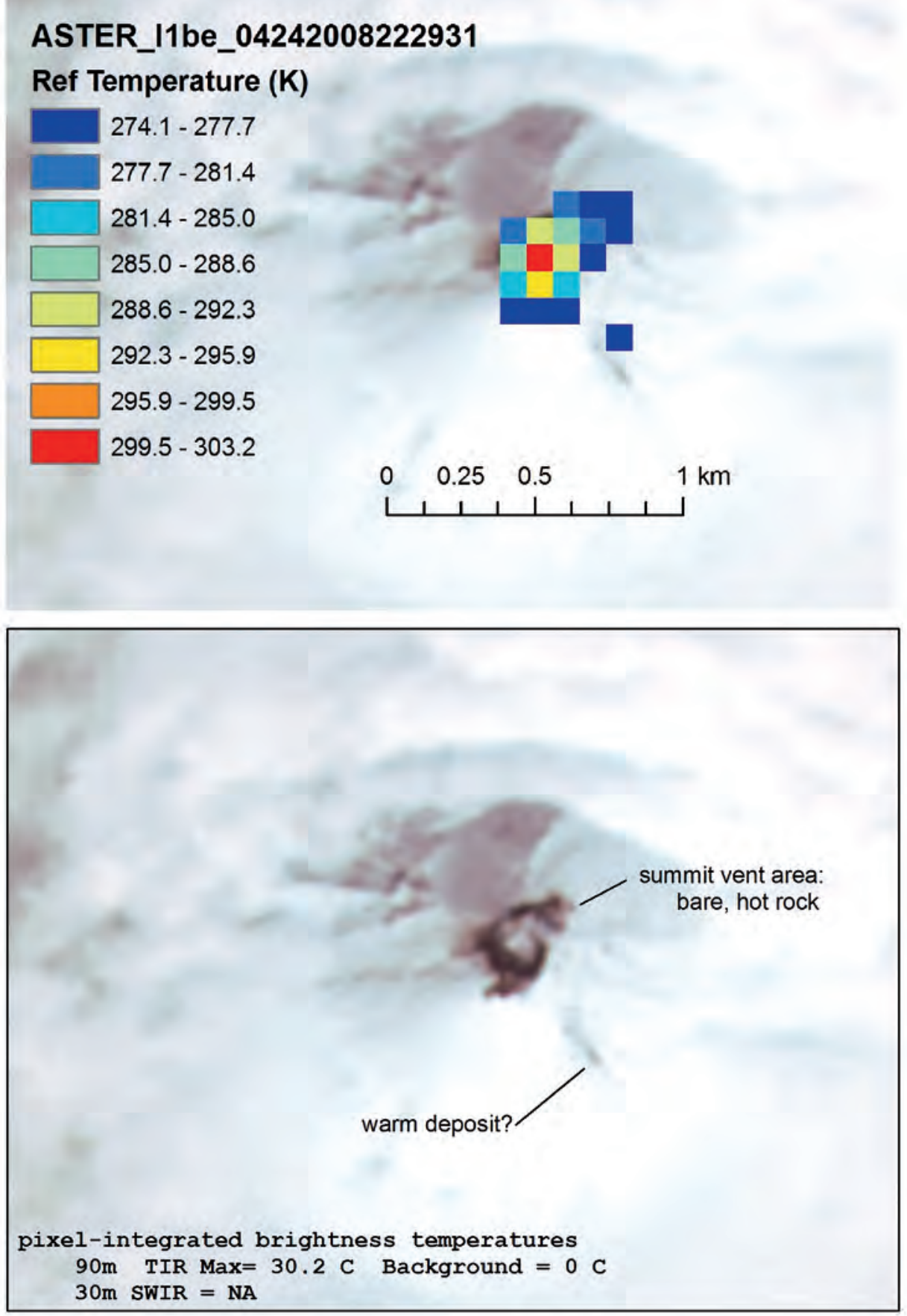

Figure 28. Close-up view of Advanced Spaceborne Thermal Emission and Reflection Radiometer (ASTER) daytime visible and thermal infrared (TIR) imagery acquired at 22:29 UTC (2:29 PM AKDT) on April 24, 2008, showing continuing volcanic activity at Cleveland. The summit area in the 15-m-resolution-visible image shows a darkened area above the snowline that corresponds to higher temperatures observed in the 90-m-resolution ASTER TIR image. The TIR data indicate a maximum pixel-integrated brightness temperature of 30.2 ${ }^{\circ} \mathrm{C}$ in a $0^{\circ} \mathrm{C}$ background at the Cleveland summit. Image data courtesy of NASA/GSFC/METI/ERSDAC/JAROS, and U.S./Japan ASTER Science Team. Image processed and assembled by R.L. Wessels, AVO/USGS. AVO database image URL: http://www.avo.alaska.edu/ images/image.php?id=14231. 


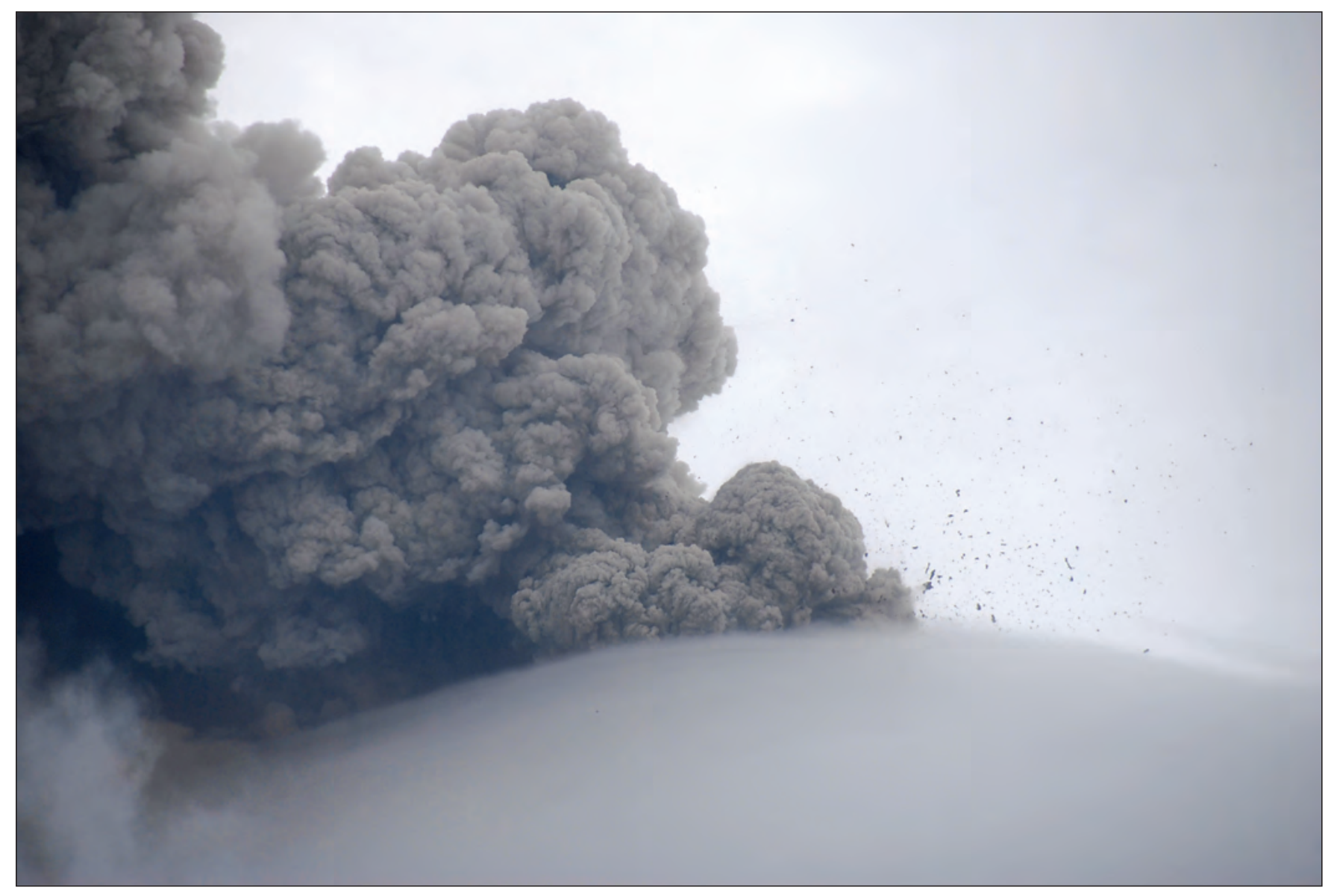

Figure 29. Ash and bombs erupting from the summit of Cleveland volcano as observed from the F/V Lady Gudny, July 21, 2008. The ash cloud ash rises from the summit crater; in other images, reddish-hued ash also rises from upper flank of the volcano interpreted as elutriate from hot blocks avalanching toward the sea. Photograph courtesy of Melinda Webster, used with permission. AVO database image URL: http://www.avo.alaska.edu/images/image.php?id=15336. 


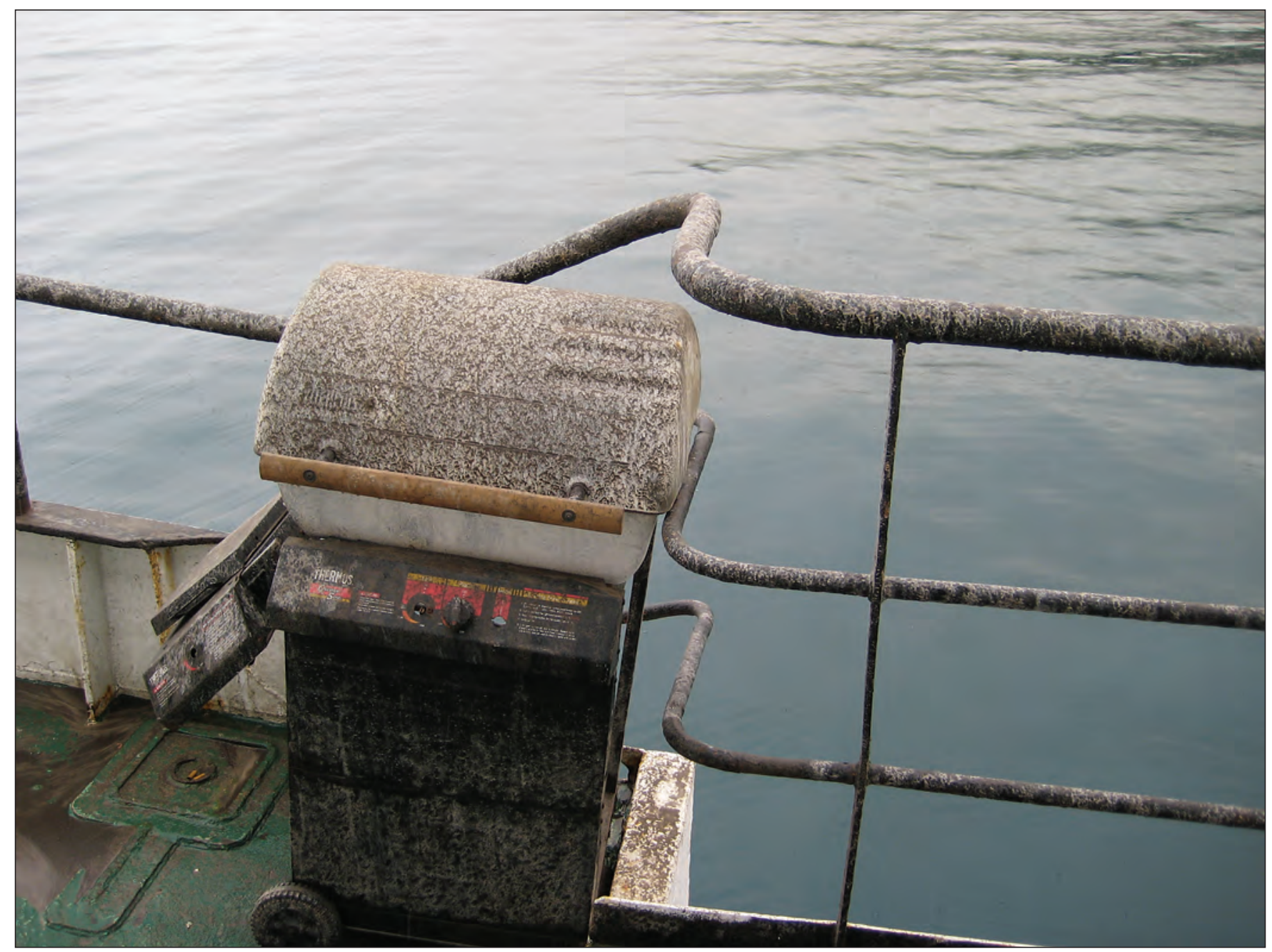

Figure 30. A dusting of ash from Cleveland volcano on the deck of the F/V Lady Gudny, July 21, 2008. Photograph courtesy of Anne Hillman, KIAL/Unalaska Community Broadcasting. AVO database image URL: http://www.avo.alaska.edu/images/image. php?id=15097. 


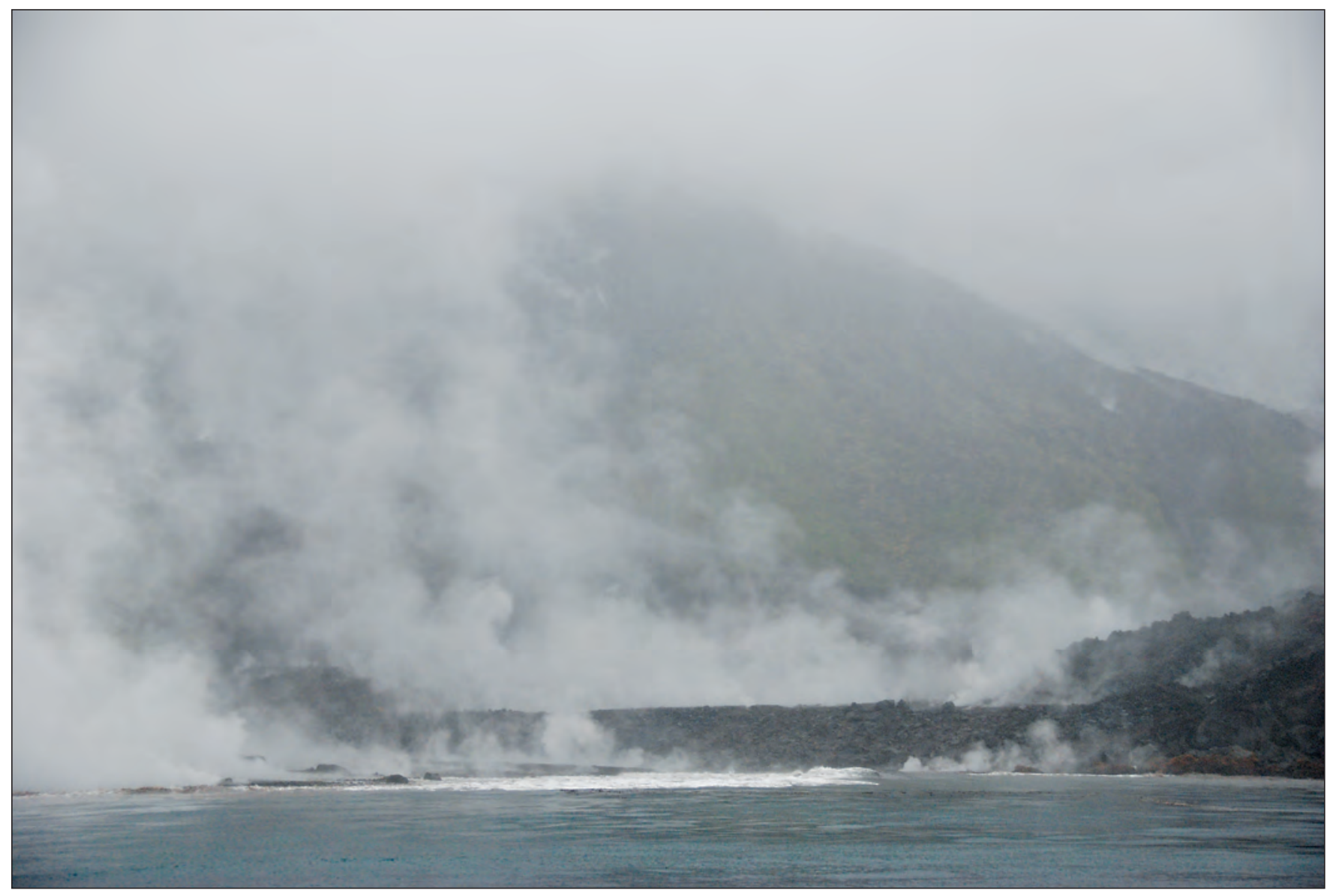

Figure 31. Steam rising from a blocky deposit produced during explosive activity at Cleveland volcano on July 21, 2008. As in the 2001 eruption (Dean and others, 2004), this deposit likely represents avalanching of hot lava blocks from a lava flow or spatterfed flow that was active high on the flank of the volcano. Photograph courtesy of Melinda Webster, used with permission. AVO database image URL: http://www.avo.alaska.edu/images/image.php?id=15373.

The volcano was relatively quiet until October 28 when an ash cloud rising to about 15,000 ft (4,600 m) ASL and drifting east was spotted in satellite imagery. On October 29, another cloud was $100 \mathrm{mi}(160 \mathrm{~km})$ long and drifting northeast at 10,000 ft (3,050 m) with little or no ash observed. A strong TA over the summit of the volcano was noted on October 30, but given the low-level nature of the recent activity, AVO did not elevate the Color Code or Alert Level.

On December 24, after a persistent TA near the summit, AVO returned to YELLOW/ADVISORY based on the observation that ash emission events often follow a protracted and strong thermal signal. About 1 week later, on January 2, 2009, Cleveland produced a short-lived ash burst to an estimated 20,000 ft (6,000 m) ASL.
The late July and August 2008 activity at Cleveland was a continuation of the intermittent explosive activity that has characterized the volcano at least since its last significant eruption in 2001 (Dean and others, 2004). Cleveland forms the western portion of Chuginadak Island, an uninhabited island in the east-central Aleutians about $73 \mathrm{~km}$ (45 mi) west of the community of Nikolski, and 1,500 km (940 mi) southwest of Anchorage. Historical eruptions have been characterized by short-lived ash explosions, lava fountaining, lava flows, and pyroclastic avalanches down the flanks. In February 2001, three explosive events produced ash clouds as high as $12 \mathrm{~km}$ $(39,000 \mathrm{ft}) \mathrm{ASL}$, a rubbly lava flow, and a hot avalanche that reached the sea (Dean and others, 2004). 


\section{Kasatochi Volcano}

CAVW\# 1101-13-

$52^{\circ} 10^{\prime} \mathrm{N} 175^{\circ} 31^{\prime} \mathrm{W}$

$314 \mathrm{~m}(1,030 \mathrm{ft})$

Kasatochi Island, west-central Aleutian Islands

\section{SIGNIFICANT EXPLOSIVE ERUPTION}

Ash clouds, ash fall, inundation of entire island by pyroclastic debris, small local tsunami, widening of summit crater.

Kasatochi, a small island volcano in the central Aleutians (fig. 32), erupted violently on August 7, 2008, after weeks of precursory seismic activity. The eruption consisted of at least five discrete explosions and a period of continuous ash emission over about 24 hours and completely blanketed the island with pyroclastic debris, enlarged the summit crater, and produced a towering eruption cloud that circled the globe. The following summary is taken largely from more detailed descriptions found in Waythomas and others (2008), Waythomas and others (2010), and Scott and others (2010).

At the time of unrest and eruption, Kasatochi was not monitored directly by seismic or other ground-based geophysical instrumentation. Additionally, very little was known about the geology and eruption history of the volcano. Four reports of activity had been tentatively attributed to Kasatochi between 1760 and 1899, but details are insufficient to fully evaluate the nature or location of the events. In 2005, a several-hour-long AVO reconnaissance visit to investigate bubbling in the summit lake (McGimsey and others, 2007) returned with photographs of the entire island, caldera walls, and samples of juvenile bombs from the young - and possibly historical—pyroclastic sheet that blanketed much of the island. Biologically, the island was much better-known. As part of the Alaska Maritime National Wildlife Refuge, Kasatochi is a long-term study site for the U.S. Fish and Wildlife Service (USFWS) who has deployed scientists to the island to monitor seabirds for 13 years (Buchheit and Ford, 2008).

The first sign of unrest in 2008 was a modest increase in regional seismic events in the general vicinity of Kasatochi, noted by AVO analysts in mid-July. Because the volcano is situated in an area of frequent tectonic seismicity, the events were first interpreted to be non-volcanic in nature. On August 4, the USFWS contacted the Alaska Volcano Observatory (AVO) and reported that their two-person biology crew on the island had felt a significant number of earthquakes "for the past several days."

By early evening August 6, increasing seismicity and the intensity of felt earthquake reports from USFWS field

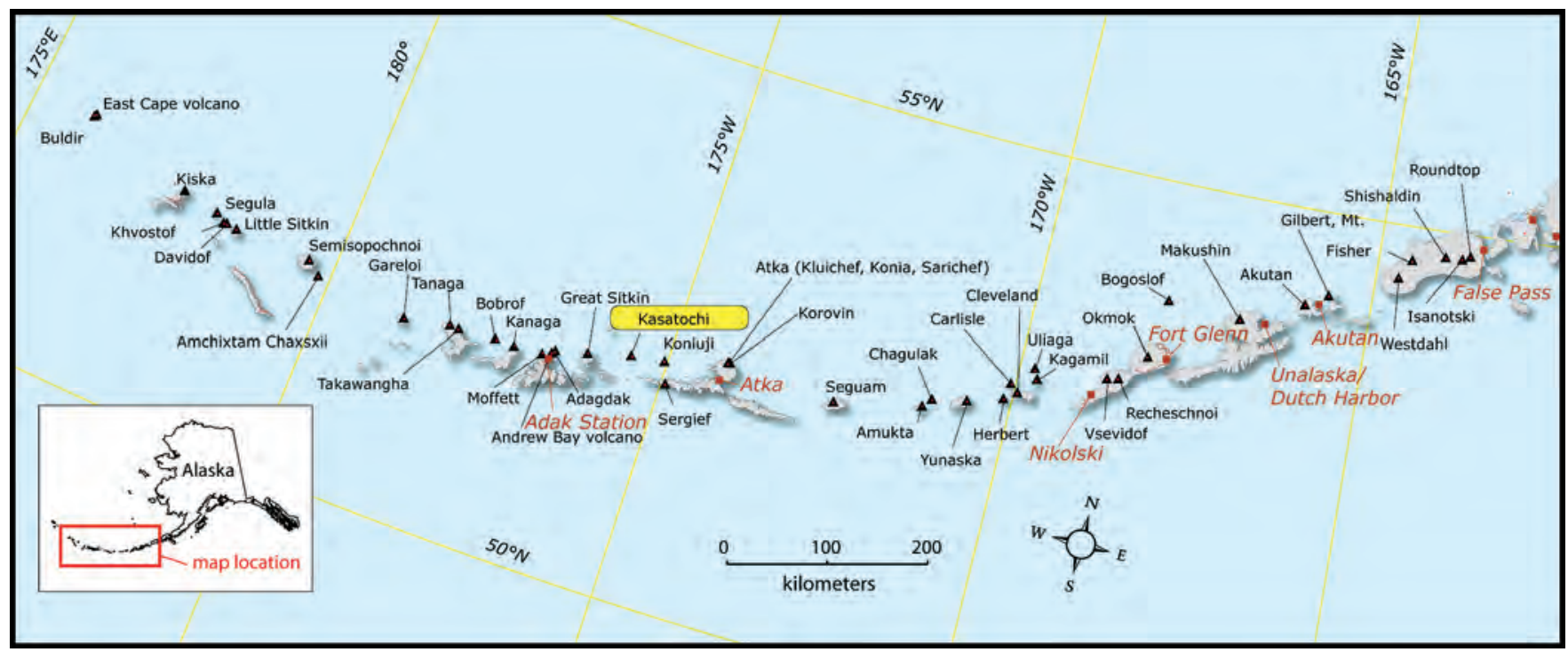

Figure 32. Location of Kasatochi Volcano in the central Aleutians. Map courtesy S. Snedigar and J. Schaefer, AVO/ADGGS. 
biologists on Kasatochi Island indicated a volcanic origin for the swarm was increasingly likely. At about 7 p.m. AKDT on August 6, AVO issued a formal Volcanic Activity Notice stating that Kasatochi had become restless and eruption was possible. Concurrently, AVO raised the Aviation Color Code and Volcano Alert Level to YELLOW/ADVISORY. AVO recommended to the USFWS that the scientists on the island be evacuated as soon as possible.

Strong seismicity continued through the night and on the morning of August 7, USFWS biologists reported periods of constant ground shaking, rockfalls, and a strong smell of sulfur. About 1 p.m. AKDT August 7, a magnitude 5.8 earthquake occurred very near the island. Soon after this earthquake, seismometers on nearby Great Sitkin Volcano (fig. 32) began recording periods of strong volcanic tremor. AVO declared ORANGE/WATCH for Kasatochi Volcano at 1:57 p.m. AKDT indicating that an eruption was now more likely to occur. At 2:23 p.m. AKDT, satellite images confirmed an eruption cloud over Kasatochi and AVO issued a Volcanic Activity Notice announcing RED/WARNING. USFWS scientists had been rescued by a local fishing boat less than 30 minutes prior to the eruption onset.

Over the next 24 hours, at least five distinct explosions were detected on the Great Sitkin seismic network. Based on analysis of satellite imagery and subsequent field investigations of pyroclastic deposits, the first two events produced relatively ash-poor, gas-rich eruption clouds that reached 13-16 km (43,000-52,000 ft) ASL. The third explosion produced an ash and gas rich plume that rose to $18 \mathrm{~km}(59,000 \mathrm{ft})$ ASL generating substantial fallout over the ocean and on islands southwest of Kasatochi. A trace amount of ash fell on eastern Adak Island about $80 \mathrm{~km}$ (50 mi) west of the volcano. Boats in the vicinity of the volcano reported up to $12 \mathrm{~cm}$ (4-5 in.) of ash fall, describing fallout as coarse sand and lapilli with clasts up to $2.5 \mathrm{~cm}$ (1 in.) across (fig. 33). Through the 1.5-3 hours of fallout, the material eventually became more of a wet mud rain. Mariners observed intensely darkened skies and lightning. The third explosion was followed by about 16 hours of continuous ash emission with two smaller explosions detected on distant seismic stations. The cumulative cloud spread over a broad area south of the Aleutian island chain (fig. 34), eventually spreading south and east over the continental United States.

AVO and USFWS scientists organized a helicoptersupported visit to Kasatochi Island on August 22 and 23, only 2 weeks after the eruption. They documented thick deposits of pyroclastic debris over the entire island. Pyroclastic deposits had extended the coastline about $400 \mathrm{~m}(1,300 \mathrm{ft})$ and were as thick as $20 \mathrm{~m}$ (66 ft) at the shoreline (fig. 35). The former USFWS cabin was not found and the formerly lush green island, home to hundreds of thousands of birds, was now a muddy, ash-covered landscape. Explosions had enlarged the summit crater by about $100 \mathrm{~m}$ (330 ft) in width. The bottom of the crater was steaming strongly from multiple vents on the crater floor. A small pond collected water from at least two vigorous streams pouring out of the lower crater wall. Over the remaining summer and into autumn, a lake gradually reformed in the bottom of this crater, milky green to gray in color and steaming vigorously. A strong, acidic gas plume issued through this lake and from other sources on the crater floor (fig. 36).

Analyzed 2008 juvenile pumice clasts are crystal-rich andesite with plagioclase, orthopyroxene, clinopyroxene, hornblende, and Ti-magnetite phenocrysts in a clear glass matrix that also contains elongate plagioclase, pyroxene, and amphibole microlites. Preliminary petrology and melt inclusion work suggests pre-eruption storage at depths of about $6.5-12.5 \mathrm{~km} \mathrm{(4-8} \mathrm{mi)} \mathrm{and} \mathrm{rapid} \mathrm{ascent} \mathrm{to} \mathrm{the} \mathrm{surface}$ (Izbekov, 2008; Izbekov and others, 2009). Gabbroic inclusions in Kasatochi pumice contained amphibole up to $11 \mathrm{~cm}$ (4 in.) in length (P. Izbekov, AVO/UAFGI and C. Nye, AVO/ADGGS written commun., 2010).

Seismicity in the vicinity of Kasatochi decreased rapidly in the days following the eruption. Satellite imagery confirmed no significant continuing ash production and AVO lowered the Aviation Color Code and Volcano Alert Level to ORANGE/ WATCH on August 9, YELLOW/ADVISORY in early September, and back to UNASSIGNED in late October (table 6).

Biological impacts of the eruption were significant in the short term; quantifying impacts to plant and animal inhabitants and the nearby ecosystem is the subject of an ongoing interdisciplinary research program (Buchheit and Ford, 2008). Aviation impacts also were severe. The ash and aerosol cloud drifted east during the week following the eruption interfering with air travel between Alaska and the conterminous U.S., causing at least 40 flight cancellations, and stranding many thousands of travelers. At least one commercial jet aircraft flew through what the flight crew reported as a thin volcanic cloud layer prompting an inspection and precautionary replacement of some equipment. A second aircraft over Canada also reported entering a sulfurous, yellowish-brown haze layer (Guffanti and others, 2010). In both cases, no in-flight malfunctions were noted and there was no discernible damage or verifiable volcanic ash contamination upon inspection.

The eruption cloud was visible for thousands of miles downwind and was the cause of some brilliant sunsets over the Midwestern U.S. The $\mathrm{SO}_{2}$ cloud from this eruption was detected by the Ozone Monitoring Instrument on NASA's EOS-Aura satellite as it circled the globe. A small tsunami [35 cm (14 in.) in amplitude] associated with the eruption was recorded by a tide gage at Adak, however, no damage was reported. 


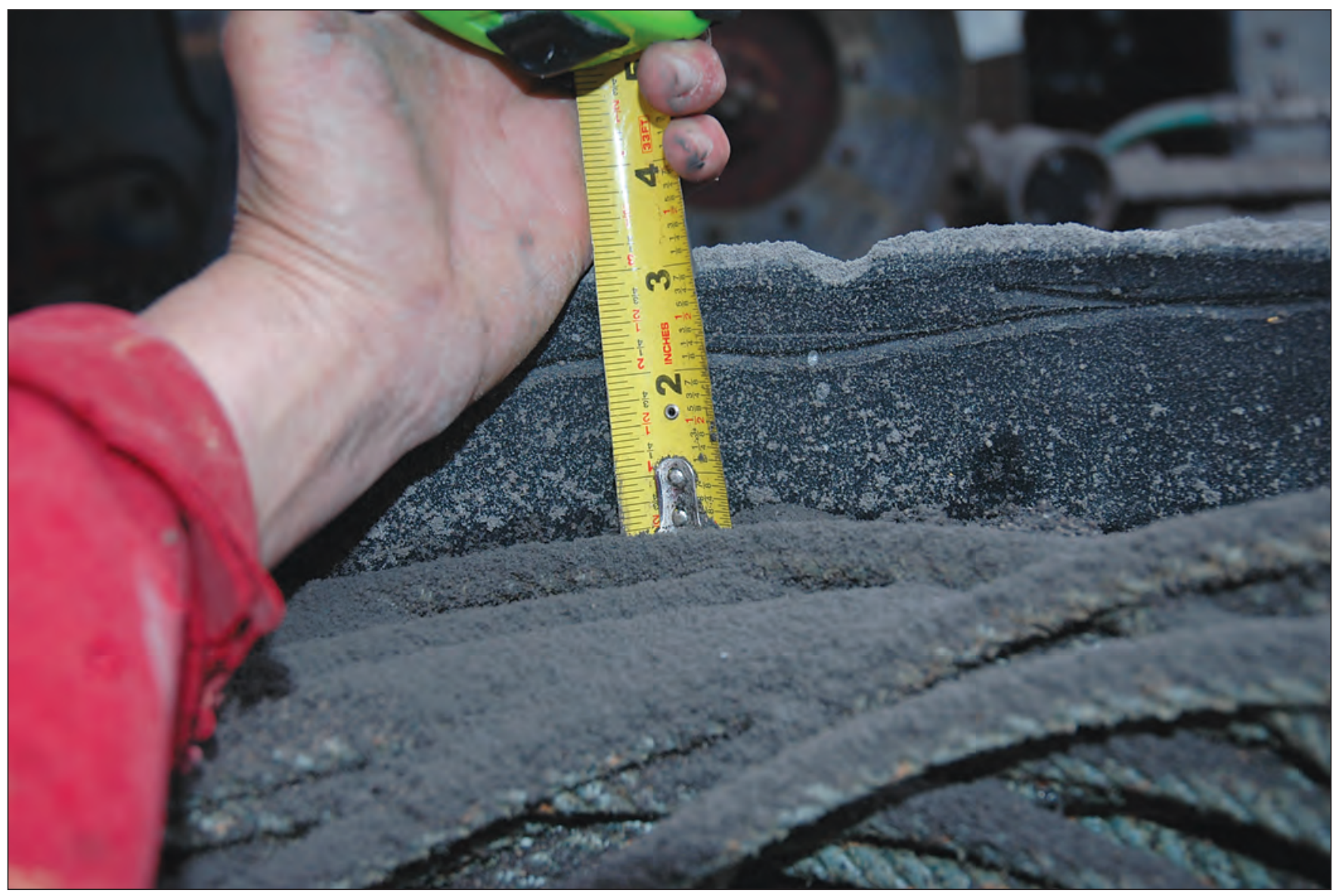

Figure 33. Tephra-fall deposit on the F/V Larisa M., which was about $13 \mathrm{~km}(8 \mathrm{mi})$ and traveling west from the volcano during a 1.5-3 hour period of intense tephra fall. Photograph by Marge Tillion, taken after the F/V Larisa M. reached Adak on August 8, 2010. AVO database image URL: http://www.avo.alaska.edu/images/image.php?id=15163. 


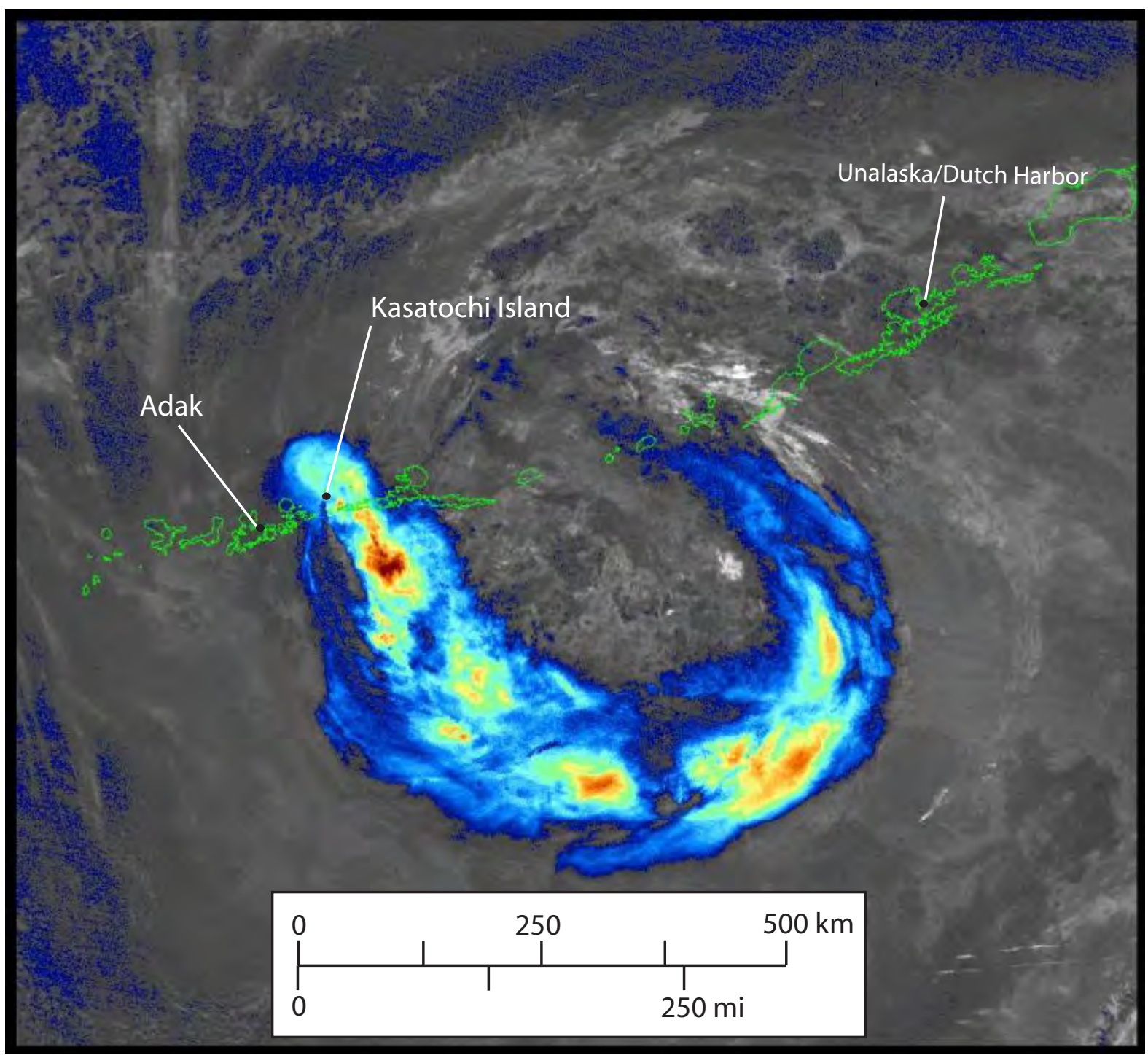

Figure 34. AVHRR image of the Kasatochi eruption cloud caught in a counter-clockwise rotating low-pressure system in the north Pacific. The brightly colored regions are areas of ash in the atmosphere. Image time 17:09 UTC on August 8, 2009, about 2 hours prior to the end of significant ash emission from Kasatochi (Scott and others, 2010). Image courtesy J. Bailey, UAFGI. AVO database image URL: http://www.avo.alaska.edu/images/image.php?id=14815. 


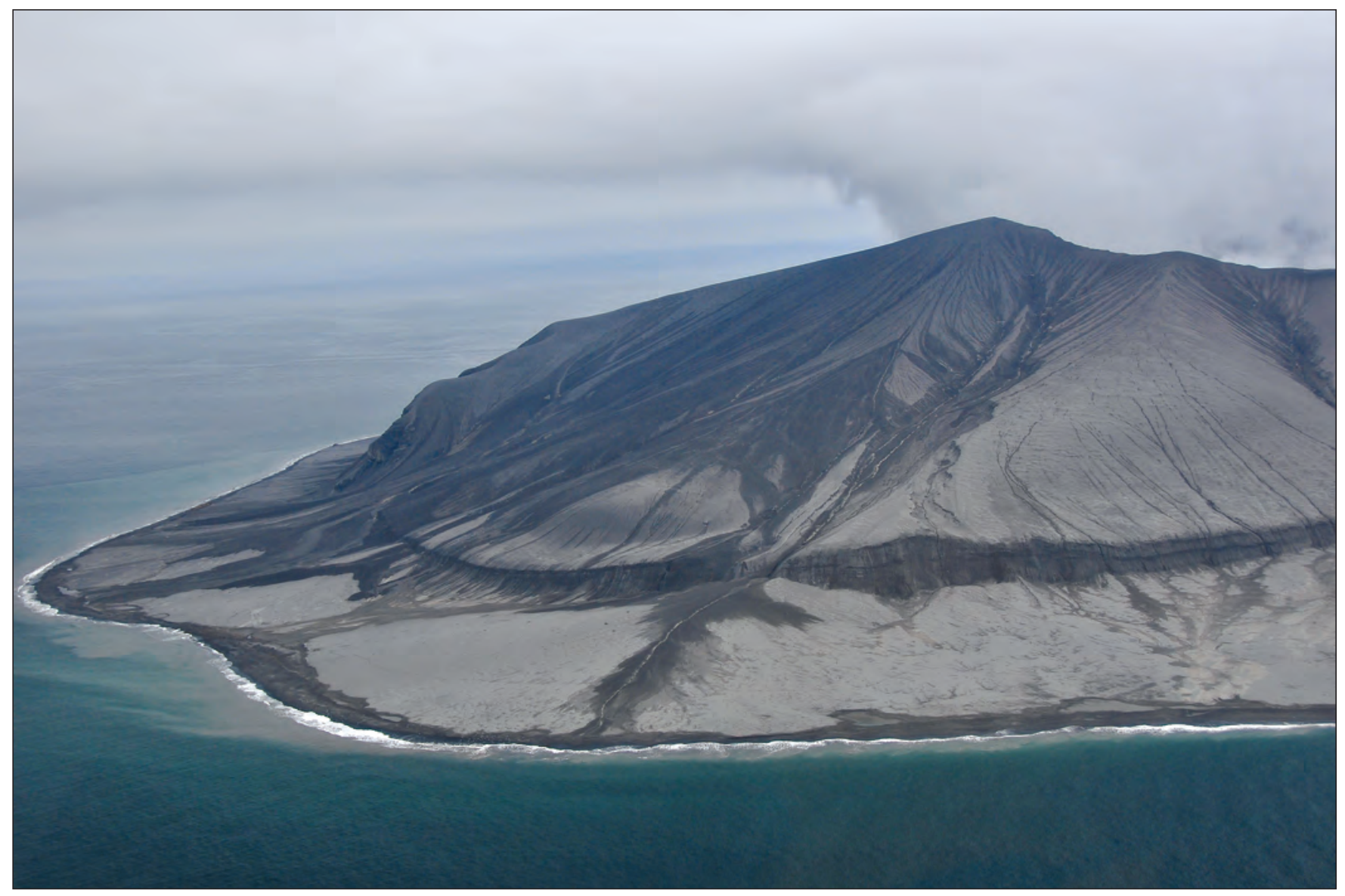

Figure 35. Aerial view of the southwest flank of Kasatochi Volcano, August 22, 2008. Pyroclastic surge and fall deposits produced during the waning stages of the eruption mantle the surface with 1-2 $\mathrm{m}(3.3-6.6 \mathrm{ft})$ of debris overlying much thicker, coarser grained pyroclastic-flow deposits. The pyroclastic flows deposited gravelly material on the flanks of the volcano and extended the shoreline about $400 \mathrm{~m}(1,300 \mathrm{ft})$ into the sea. The prominent cliff like feature that rims the low flank of the volcano is a wave cut cliff that marks the former shoreline. Photograph by C. Waythomas, AVO/USGS. AVO database image URL: http://www.avo.alaska.edu/ images/image.php?id=15306. 

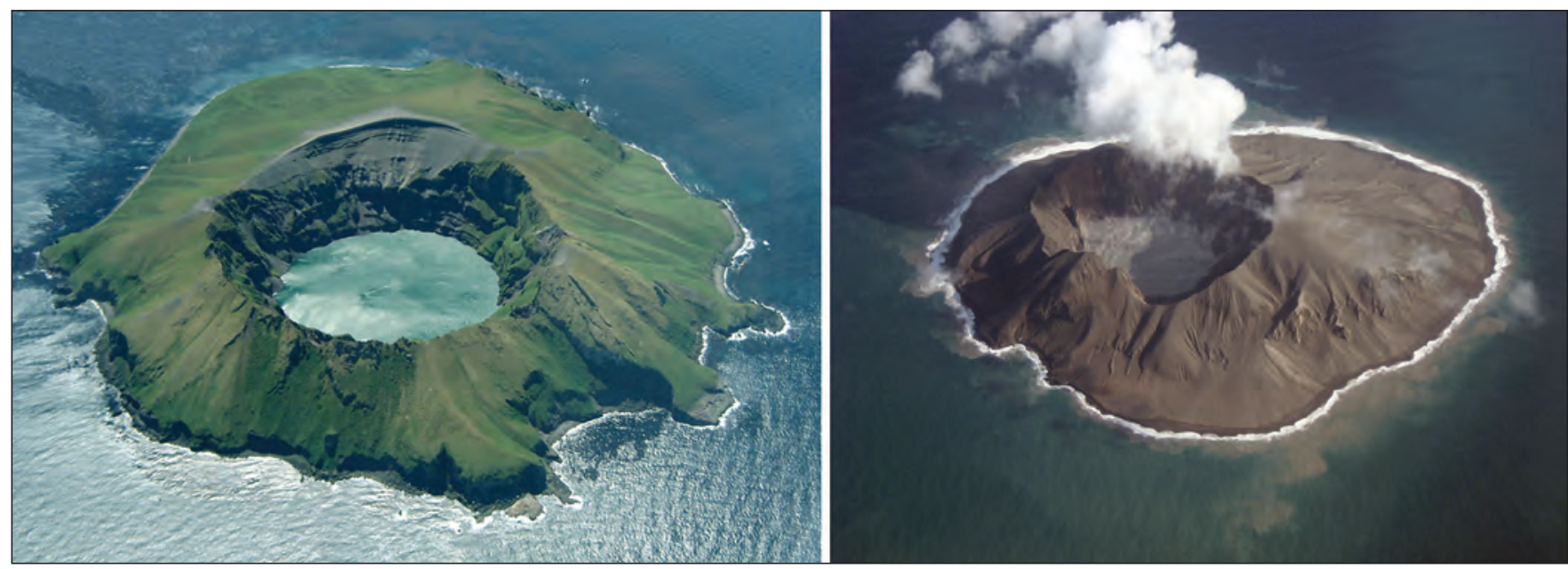

Figure 36. Kasatochi Volcano before and after the 2008 eruption. On left, aerial image from July 9, 2008, south at the top. On right, aerial image on October 23,2008 , east at the top, showing the pervasive pyroclastic mantle covering the island. By this time, a shallow, gray, acidic lake had reformed in the widened summit crater. Photographs courtesy Jerry Morris, Security Aviation.

Remote Kasatochi Island rises from the seafloor at the northern end of a submarine ridge in the central Aleutians about $840 \mathrm{~km}$ (522 mi) west-southwest of the tip of the Alaska Peninsula. Prior to the 2008 eruption, the island measured about $2.6 \times 3 \mathrm{~km}(1.6 \times 1.9 \mathrm{mi})$ and had a central, lake-filled, vertical-walled summit crater about $800 \mathrm{~m}(2,600 \mathrm{ft})$ in diameter. The surface of the lake was estimated to be about $50 \mathrm{ft}$ (15 m) ASL in 2005 using the helicopter's radar altimeter (McGimsey and others, 2007). The record of historical eruptive activity at Kasatochi is poorly known. The island was reported as "emerging" in 1760 by Grewingk (1850 and as cited in Miller and others, 1998) and as "smoking" in 1827 and 1828. USFWS observers reported 'increased steaming' at Kasatochi Volcano following a 6.0 magnitude earthquake in June 1996 (Neal and McGimsey, 1997); however, the exact source of steaming is not recorded. USFWS scientists on the island reported bubbling through the crater lake from 2005 to 2007 (McGimsey and others, 2007, 2011; Neal and others, 2009c). 


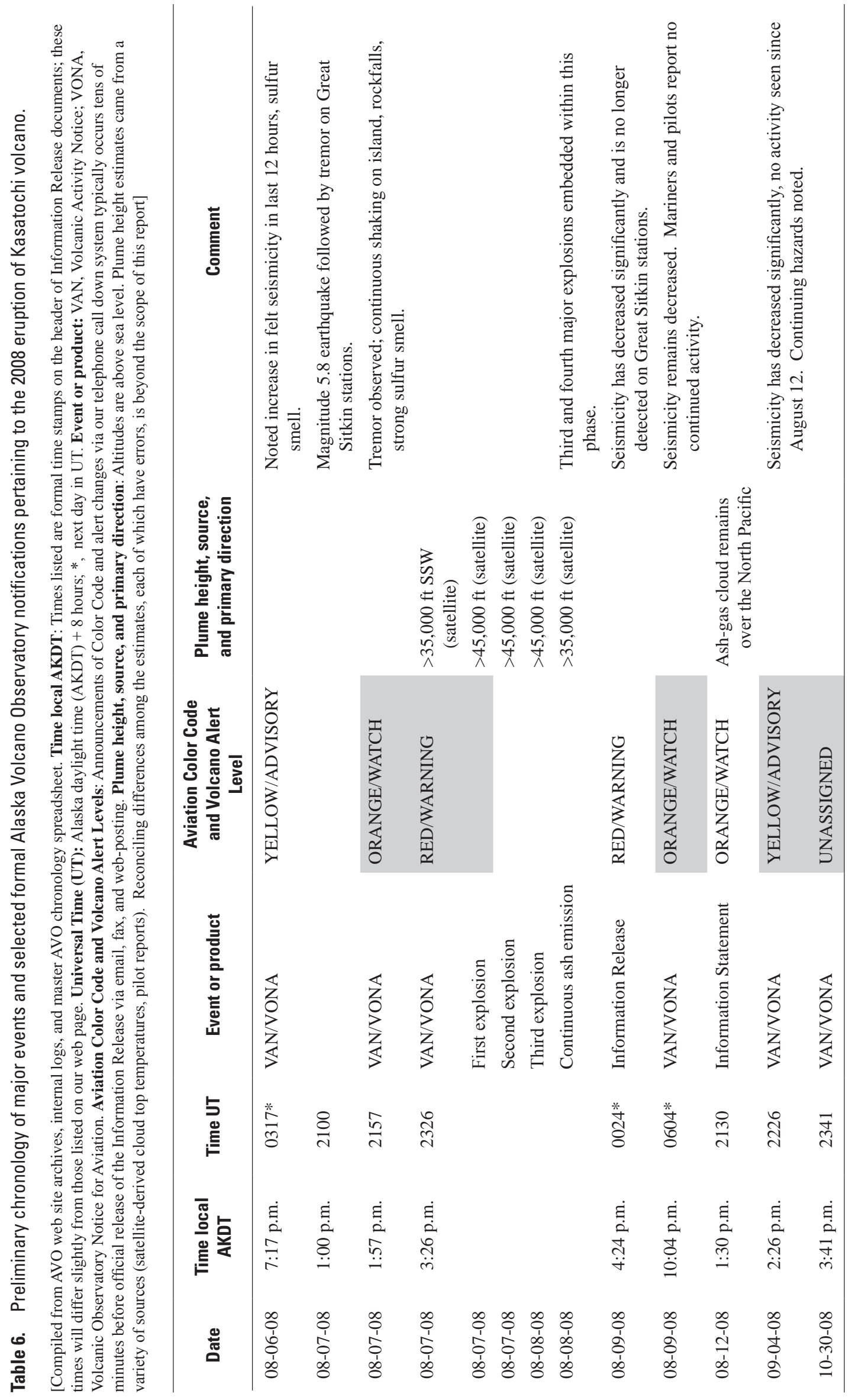




\section{Volcanic Activity, Kamchatka Peninsula, and the Northern Kurile Islands, Russia}

More than 60 potentially active volcanoes on Russia's Kamchatka Peninsula and Kurile Islands pose a serious threat to aircraft in the North Pacific, especially for planes on the North Pacific, Russian Trans-East, and Cross-Polar air routes (Neal and others, 2009a). The primary responsibility for monitoring and alerting the aviation community to activity in Russia lies with the Kamchatka Volcanic Eruptions Response Team (KVERT) for Kamchatka and the northern Kuriles, and the Sakhalin Volcanic Eruption Response Team (SVERT) for the remaining Kuriles (next section).

KVERT is a cooperative program consisting of scientists from the Institute of Volcanology and Seismology (IVS), the Kamchatka Branch of Geophysical Services (KBGS), and AVO. The KBGS component of KVERT monitors 11 of the most frequently active volcanoes in Kamchatka and on the northern Kurile Islands of Paramushir and Atlasova with one or more seismometers (fig. 37; table 7). KVERT staff analyzes AVHRR and MODIS satellite data daily and examine real-time, web-camera images of Sheveluch, Klyuchevskoy, and Bezymianny Volcanoes. In addition, KVERT receives occasional reports of volcanic activity from scientific observers in the communities of Severo-Kurilsk on Paramushir, Klyuchi, and Kozyrevsk. KVERT also receives reports from scientific field parties working in the vicinity of Karymsky Volcano, and pilot reports of volcanic activity are relayed to KVERT from the local Civil Aviation Meteorological Center at Yelizovo Airport. AVO conducts satellite monitoring of portions of the Russian volcanic arc and shares twice-daily satellite monitoring reports with KVERT staff via email. By formal agreement, AVO also assists with dissemination of hazard information for eruptions from the Kuriles and Kamchatka.

In January 2008, KVERT began using a new AVHRR receiving station to obtain as many as 12 satellite images per day for the Kamchatka region. This system provides imagery of lower resolution than High Resolution Picture Transmission (HRPT) data, although its speed and frequency of images should prove very helpful to KVERT's monitoring efforts. KVERT also launched complete English language version of its web site in 2008.

2008 was a volcanically quiet year in Kamchatka compared with the past several years. In December, phreatic activity at Koryaksky Volcano adjacent to the community of Yelizovo (fig. 37) prompted concern for impacts on Kamchatka's most populous city as well as its International airport. A total of eight volcanoes in Kamchatka and on the northern Kurile island of Paramushir were active requiring some level of AVO response in 2008. Summaries of this activity and related Color Code changes for Russian volcanoes are listed in tables 8 and $\underline{9}$. 


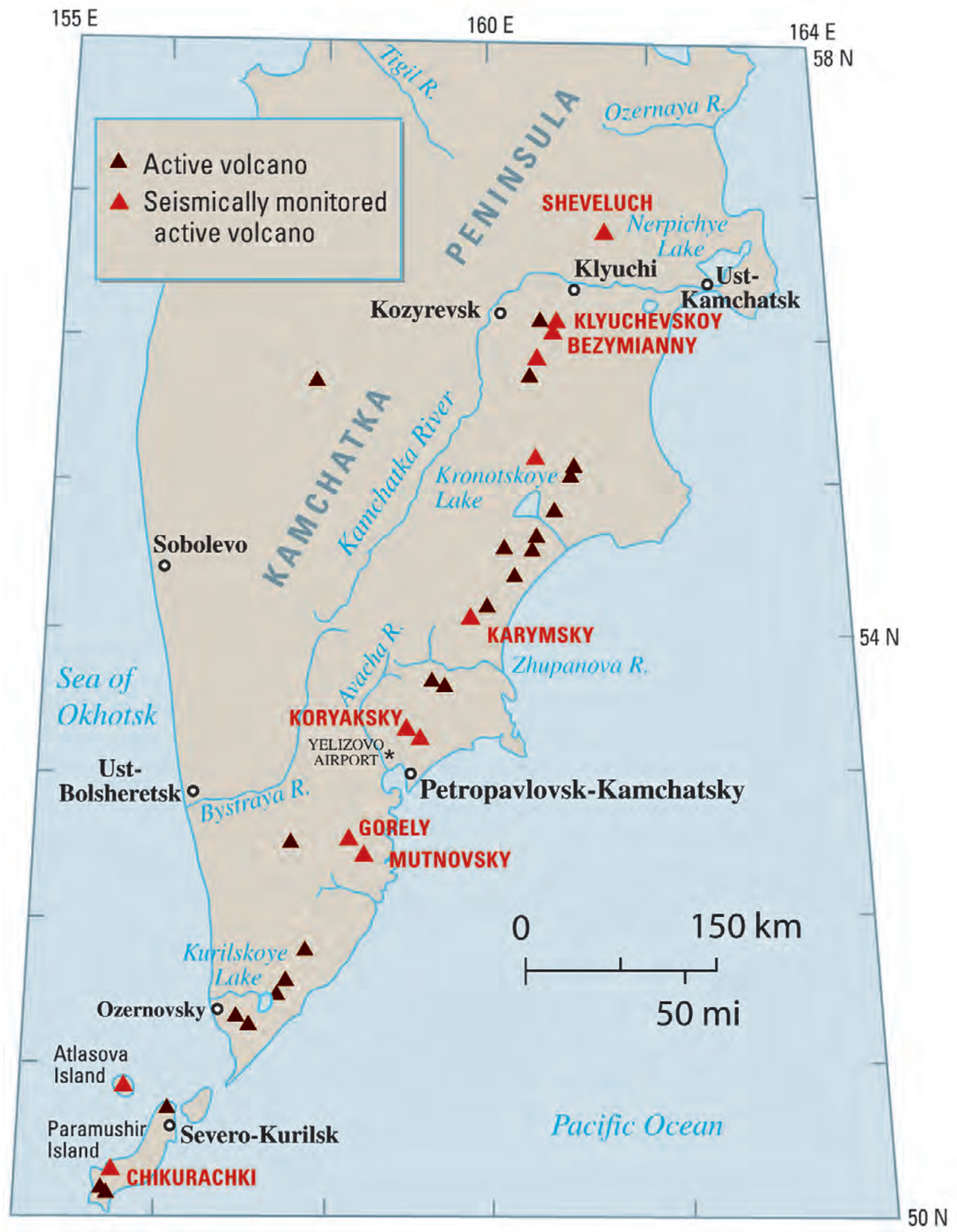

Figure 37. Kamchatka Peninsula and the northern Kurile Islands of Alaid and Paramushir. Volcanoes discussed in this report are labeled with bold red type. 
Table 7. Seismically monitored volcanoes of Kamchatka as of December 2008.

[Compiled by S. Senyukov, Kamchatka Branch of Geophysical Surveys (KBGS), and C.A. Neal, Alaska Volcano Observatory. Prior to 1979, other Russian scientific institutes maintained programs of volcano monitoring in Kamchatka (a partial listing includes: 1961-71, Pacific Seismological Department of Institute of Earth Physics; 1972-78 — Institute of Volcanology). PK_-Petropavlovsk, Kamchatska]

\begin{tabular}{|c|c|c|}
\hline Volcano & $\begin{array}{l}\text { Approximate start date of continuous seismic } \\
\text { monitoring by KEMSD (now KBGS) }\end{array}$ & $\begin{array}{l}\text { Other monitoring techniques } \\
\text { used routinely }\end{array}$ \\
\hline \multirow[t]{4}{*}{ Sheveluch } & Seismic station - February 1987 & \multirow{4}{*}{$\begin{array}{l}\text { Near real-time video system (2002); direct observation from } \\
\text { nearby Klyuchi; satellite imagery. }\end{array}$} \\
\hline & Telemetered data - 1980 & \\
\hline & Digital format - September 1996 & \\
\hline & Near-real time processing - 1999 & \\
\hline \multirow[t]{4}{*}{ Klyuchevskoy } & Seismic station - 1961 & \multirow{4}{*}{$\begin{array}{l}\text { Near real-time video system (2000); direct observation from } \\
\text { nearby Klyuchi and Kozyrevsk; satellite imagery. }\end{array}$} \\
\hline & Telemetered data - 1987 & \\
\hline & Digital format - September 1996 & \\
\hline & Near-real time processing - 1999 & \\
\hline \multirow[t]{4}{*}{ Bezymianny } & Seismic station - 1961 & \multirow{4}{*}{$\begin{array}{l}\text { Near real-time video system (2003); Direct observation from } \\
\text { nearby Kozyrevsk; satellite imagery. }\end{array}$} \\
\hline & Telemetered data - October 1988 & \\
\hline & Digital format - September 1996 & \\
\hline & Near-real time processing - 1999 & \\
\hline \multirow[t]{4}{*}{ Plosky Tolbachik } & Seismic station - January 1977 & \multirow[t]{4}{*}{ Direct observation from nearby Kozyrevsk; satellite imagery. } \\
\hline & Telemetered data - November 1990 & \\
\hline & Digital format - September 1996 & \\
\hline & Near-real time processing - 1999 & \\
\hline \multirow[t]{4}{*}{ Kizimen } & Seismic station - July 2003 & \multirow[t]{4}{*}{ Satellite imagery. } \\
\hline & Telemetered data - July 2003 & \\
\hline & Digital format - July 2003 & \\
\hline & Near-real time processing - July 2003 & \\
\hline \multirow[t]{3}{*}{ Karymsky } & Telemetered data - September 1989 & \multirow[t]{3}{*}{ Field observation; satellite imagery. } \\
\hline & Digital format - January 1996 & \\
\hline & Near-real time processing - 1996 & \\
\hline \multirow[t]{4}{*}{ Koryaksky } & Seismic station - April 1963 & \multirow[t]{4}{*}{ Direct observation from PK; satellite imagery. } \\
\hline & Telemetered data - 1975 & \\
\hline & Digital format - January 1996 & \\
\hline & Near-real time processing - 1996 & \\
\hline \multirow[t]{4}{*}{ Avachinsky } & Seismic station - April 1963 & \multirow[t]{4}{*}{ Direct observation from PK; satellite imagery. } \\
\hline & Telemetered data - July 1976 & \\
\hline & Digital format - January 1996 & \\
\hline & Near-real time processing - 1997 & \\
\hline \multirow[t]{3}{*}{ Gorely } & Telemetered data - July 1980 & \multirow[t]{3}{*}{ Direct observation from PK; satellite imagery. } \\
\hline & Digital format - January 1996 & \\
\hline & Near-real time processing - 1996 & \\
\hline \multirow[t]{3}{*}{ Mutnovsky } & Telemetered data - July 1980 & \multirow[t]{3}{*}{ Direct observation from PK; satellite imagery } \\
\hline & Digital format - January 1996 & \\
\hline & Near-real time processing - 1996 & \\
\hline \multirow[t]{3}{*}{ Alaid } & Telemetered data - August 2001 & \multirow[t]{3}{*}{ Satellite imagery } \\
\hline & Digital format - August 2001 & \\
\hline & Near-real time processing - August 2001 & \\
\hline
\end{tabular}


Table 8. Summary of VOLCANIC ACTIVITY on Kamchatka Peninsula and in the Kurile Islands, Russia, 2008.

[Location of volcanoes shown in figures 37 and $\underline{46}$ ]

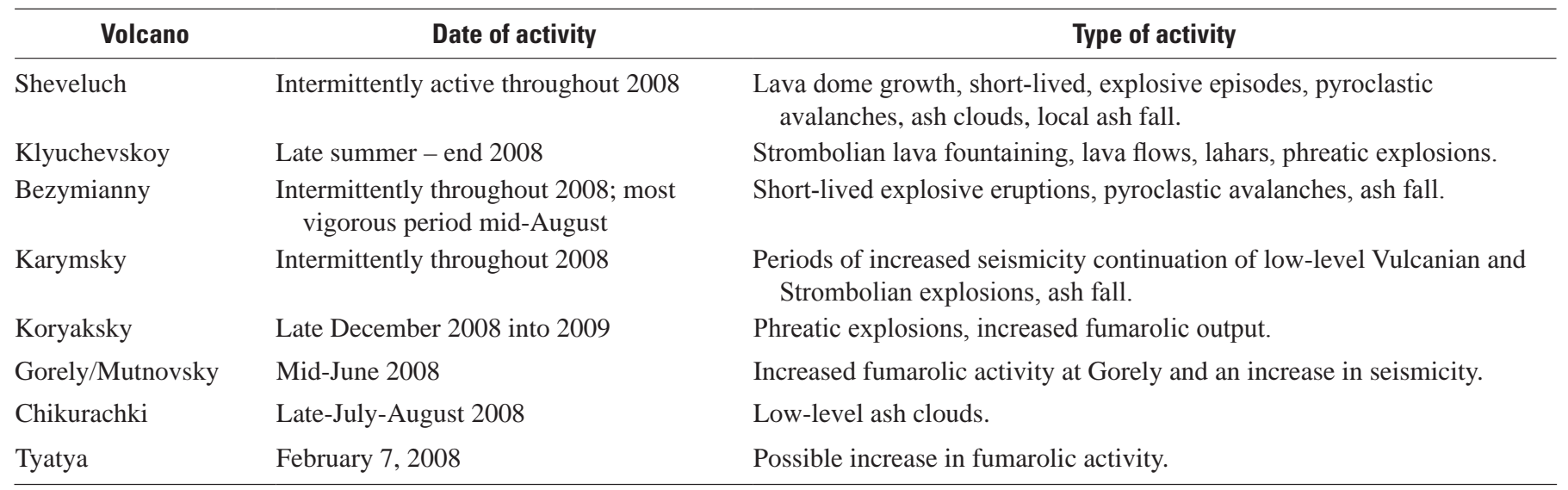

Table 9. Kamchatkan volcanoes with Color Code changes in 2008.

[Description of Level of Concern Color Code used in Russia is shown in appendix 2. Times are only shown where Color Code changes were short-lived during rapidly evolving events. Dates are from the KVERT Information Release and reflect the date in Kamchatka]

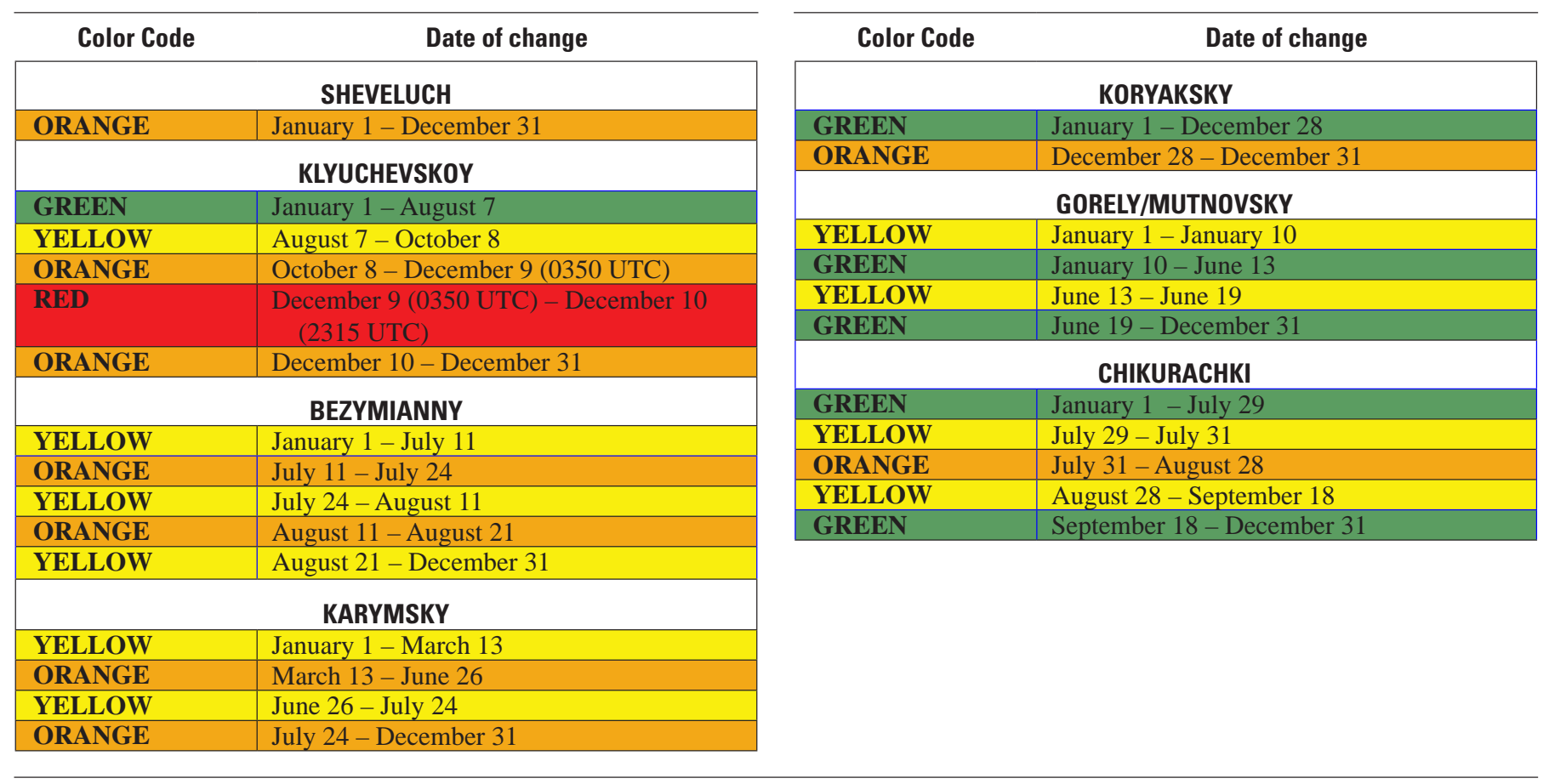




\title{
Sheveluch Volcano
}

\author{
CAVW\# 1000-27=
}

$56^{\circ} 38^{\prime} \mathrm{N} 161^{\circ} 21^{\prime} \mathrm{W}$

$3,283 \mathrm{~m}(10,771 \mathrm{ft})$

Kamchatka Peninsula

\section{LAVA DOME GROWTH CONTINUES}

Occasional ash plumes, pyrochlastic avalanches.

The protracted lava dome eruption of Sheveluch continued throughout 2008 but without major explosive events that sent voluminous ash plumes above $9 \mathrm{~km}(30,000 \mathrm{ft})$ ASL. The volcano spent the entire year at Level of Concern Color Code ORANGE. Weekly observational summaries reported elevated seismicity (many shallow earthquakes and intermittent tremor), possible ash plumes (based on seismicity) as high as 6-7 km (20,000-23,000 ft) ASL, and occasional ash clouds captured on video imagery reaching several to $5 \mathrm{~km}$ $(16,000 \mathrm{ft})$ ASL. During periods of quiescence, a fumarolic plume commonly rose above the active dome. Satellite imagery detected strong thermal anomalies over the active lava dome fairly consistently. In late February and into March, video images also recorded small hot avalanches off the active lava dome. Other avalanche events were inferred from seismic data.

Satellite monitoring of Sheveluch allowed for detection of ash plumes and associated fallout intermittently as weather allowed; clear MODIS views of the volcano in mid-February showed distinctive ash deposits on the snow-covered terrain southeast of the volcano. In early April, seismicity suggested nearly continuous avalanching of debris from the lava dome. On-site observers reported weak ash plumes over the dome on April 20-23. At the same time, seismicity suggested intermittent ash-gas explosions and perhaps a period of increased lava effusion. Activity picked up again slightly in May and on May 20, a large avalanche from the lava dome sent ash to $4 \mathrm{~km}(13,000 \mathrm{ft})$.
The lava dome continued to grow for the remainder of the year with periods of increased avalanche activity and more vigorous plume production (fig. 38). A thermal anomaly was consistently observed over the location of the lava dome and the accumulating fan of hot pyroclastic debris to the south of the dome. Ash falls related to more vigorous activity occurred in Klyuchi (fig. 37) in early October and late November. Volcanic clouds associated with this activity rarely rose more than $8 \mathrm{~km}$ (26,000 ft) ASL and were traceable on satellite imagery up to $100 \mathrm{~km}$ (60 mi) downwind. The background fumarolic plume that was often visible above the lava dome also produced, at times, visible plumes that drifted downwind.

Sheveluch Volcano is one of the largest and most active of Kamchatkan volcanoes with at least 60 large eruptions during the Holocene (Bogoyavlenskaya and others, 1985; Ponomareva and others, 1998). Historical eruptive activity has been characterized by lava-dome growth and explosive collapse, often accompanied by large debris avalanches. A catastrophic flank collapse event in 1964 formed the modern amphitheater within which the active lava dome is now growing (Zharinov and others, 1995). The current phase of lava-dome growth and explosive activity began in late September 1980 and has continued intermittently into 2010. 


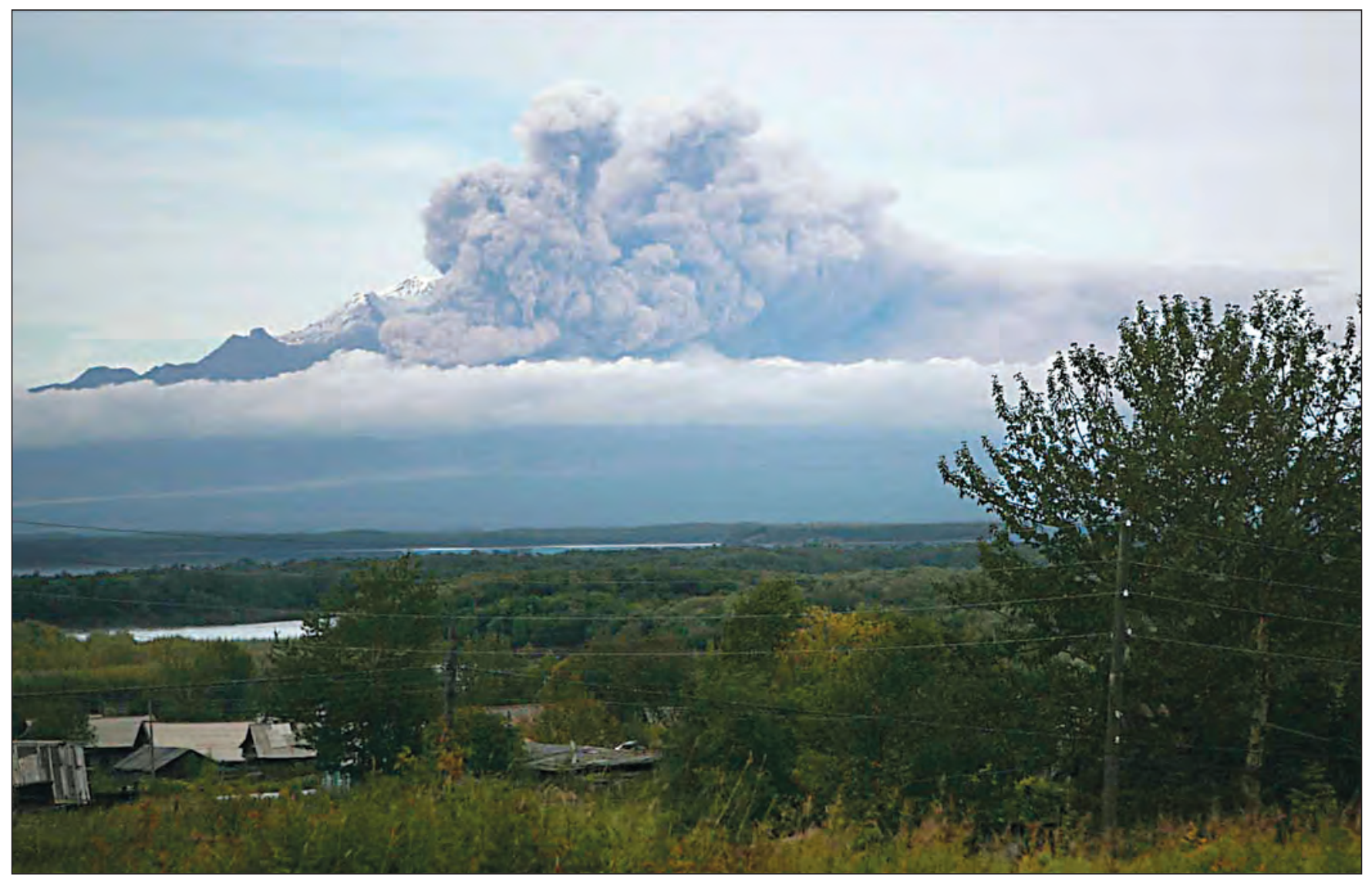

Figure 38. Ash cloud rising from a pyroclastic avalanche off the active lava dome at Sheveluch Volcano, September 13, 2008. View to the northeast from the town of Klyuchi. Photograph by Y. Demyanchuk, IVS. 


\title{
Klyuchevskoy Volcano
}

\author{
CAVW\# 1000-26=
}

$56^{\circ} 03^{\prime} \mathrm{N} 160^{\circ} 39^{\prime} \mathrm{E}$

$4,750 \mathrm{~m}(15,585 \mathrm{ft})$

Kamchatka Peninsula, Russia

INCREASED EXPLOSIVITY AND LAVA FLOW PRODUCTION

Ash falls on nearby communities, phreatic explosions as lava flow interacts with glacial ice

Klyuchevskoy began the year at Level of Concern Color Code GREEN with low levels of unrest following the explosive Strombolian and Vulcanian activity of summer 2007 (McGimsey and others, 2011). Beginning in June, seismicity consisting of many shallow earthquakes and intermittent volcanic tremor intensified and the size and temperature of the satellite-detected thermal anomaly also increased. KVERT elevated the Level of Concern Color Code to YELLOW on August 7.

After 2 months of elevated unrest, Strombolian eruptions from the summit crater began on October 8 and KVERT declared Level of Concern Color Code ORANGE. The glow of incandescence had been sighted from the town of Klyuchi as early as August 27, suggesting that activity slowly accelerated to a level where lava was visible above the crater rim by early October. Weak ash clouds rose several hundred meters above the crater rim and intermittent, explosion sounds were heard in Klyuchi. On November 21, a lava flow was sighted on the northwest flank of the volcano, indicating that the level of lava in the summit crater had risen to the point of overflow. Accompanying this, a large thermal anomaly was visible in satellite imagery. Observers noted volcanic bombs lofted about $500 \mathrm{~m}$ (1,600 ft) above the crater rim. Ash clouds stayed mostly below $6.5 \mathrm{~km}(21,000 \mathrm{ft})$ but drifted as far as $100 \mathrm{~km}$ (60 mi) downwind as observed on satellite images.
On December 9, activity intensified and Strombolian explosions sent ash possibly as high as $7.5 \mathrm{~km}(25,000 \mathrm{ft})$ ASL. KVERT declared Level of Concern Color Code RED for a period of about 20 hours. The northwest-flank lava flow had traveled about $2.5 \mathrm{~km}(1.5 \mathrm{mi})$ down slope by this time and phreatic activity at the intersection of the lava flow with glacial ice was reported by local observers (figs. 39 and 40) and captured in the web camera. Ash falls were noted in the town of Klyuchi on December 6 and 9 and in town of Kozyrevsk on December 27. The ash clouds seen in satellite images extended as far as $700 \mathrm{~km}$ (430 mi) east of the volcano at altitudes as high as $8 \mathrm{~km}(26,000 \mathrm{ft})$ ASL. This high level of activity continued into 2009, prompting frequent Volcanic Ash Advisory (VAA) messages from Tokyo VAAC.

Klyuchevskoy, the tallest active volcano in Eurasia, is frequently active with Strombolian to Vulcanian explosions and occasional lava-flow production from the main vent in the steep-walled summit crater or from flank vents (Khrenov and others, 1991). Explosive eruptions have been recorded in nearly every decade and at multiple times during most years since the early 1700s (Simkin and Siebert, 1994). 


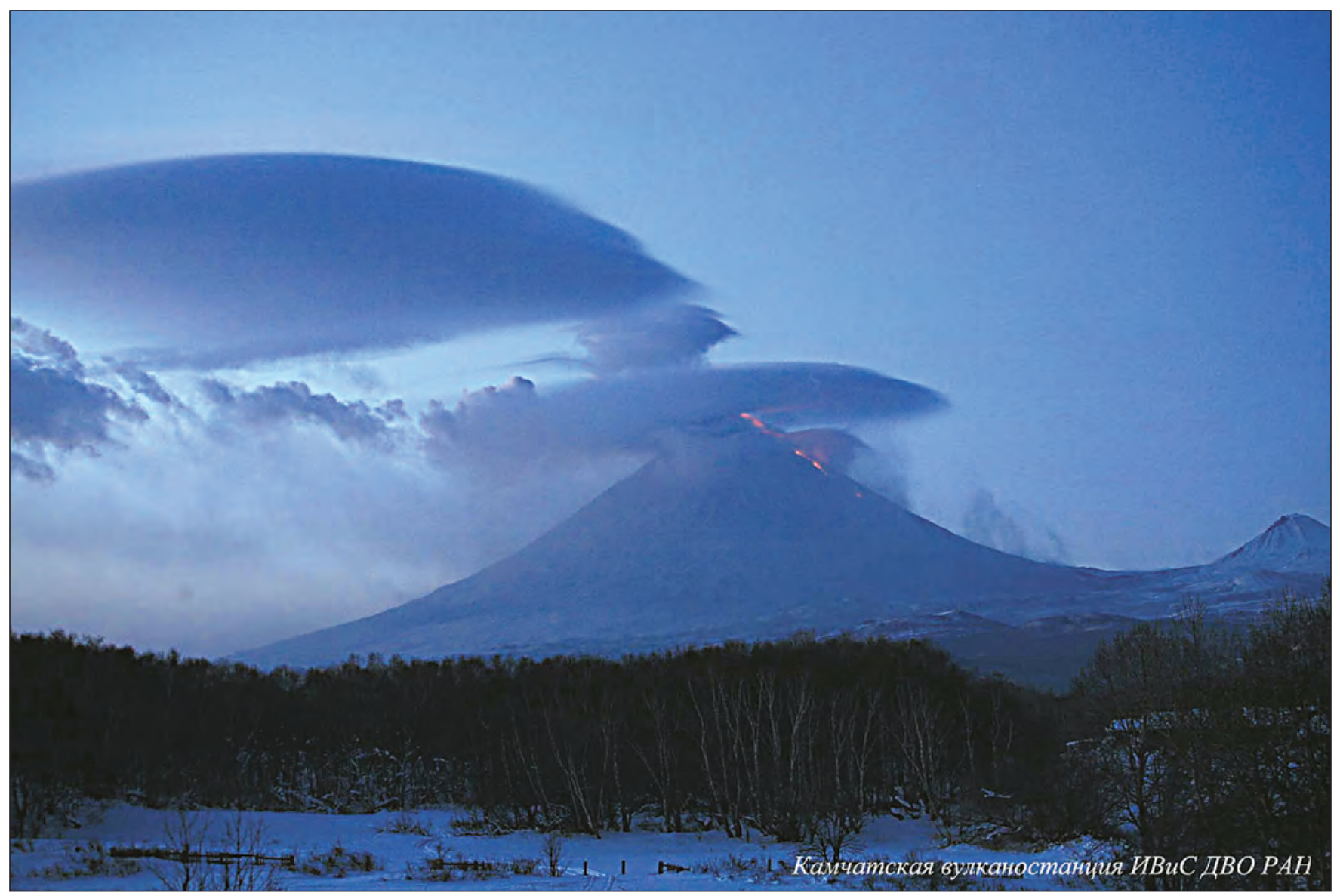

Figure 39. A lava flow descending the Krestovskay channel on the northwest flank of Klyuchevskoy Volcano, December 10, 2008. Photograph by Y. Demyanchuk, IVS. 


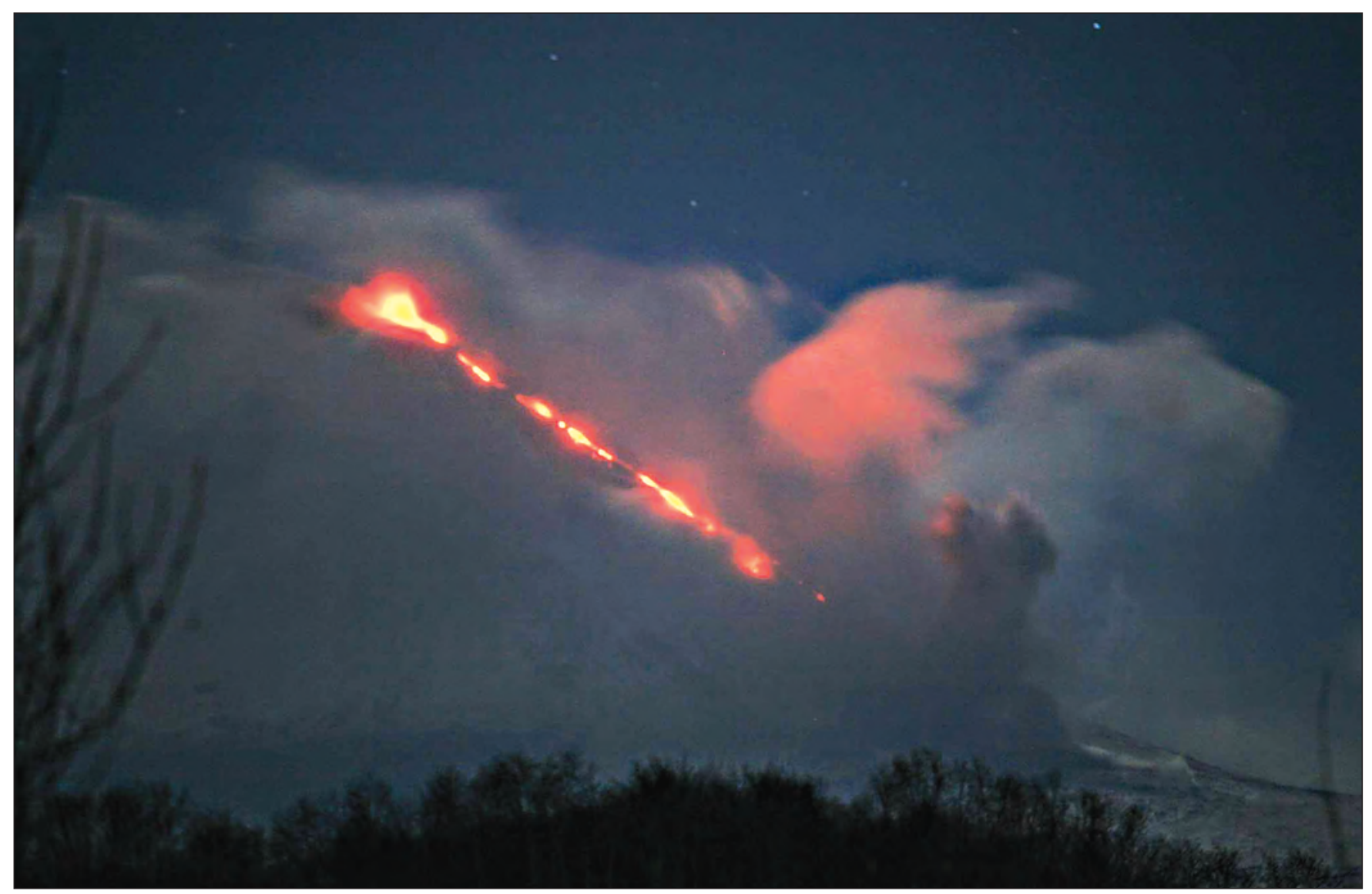

Figure 40. Small phreatic explosions and ash clouds forming as lava flowing down the northwest flank of Klyuchevskoy Volcano interacts with glacial ice, December 12, 2008. Photograph by Y. Demyanchuk, IVS. 


\author{
Bezymianny Volcano \\ CAVW\# 1000-25= \\ $55^{\circ} 58^{\prime} \mathrm{N} 160^{\circ} 36^{\prime} \mathrm{W}$ \\ $2,882 \mathrm{~m}(9,456 \mathrm{ft})$ \\ Kamchatka Peninsula, Russia \\ INTERMITTENT LAVA DOME GROWTH AND EXPLOSION \\ A significant short-lived explosion and ash cloud in August
}

Growth of the lava dome at Bezymianny Volcano continued in 2008. The volcano began the year quietly at Level of Concern Color Code YELLOW. Typically, a fumarolic plume rose above the actively growing dome and seismicity was at or slightly above background. A thermal anomaly at the approximate position of the lava dome was common in satellite images.

On July 11, following the appearance of volcanic tremor and onset of avalanches from the active lava dome, KVERT raised the Level of Concern Color Code to ORANGE. The concern for a larger explosion abated quickly, however, and on July 24, KVERT reverted to YELLOW but noted that lava was actively extruding from the summit lava dome (fig. 41).

A second increase in the frequency of hot avalanches, the size and temperature of the thermal anomaly, and seismicity prompted an uptick back to Level of Concern Color Code ORANGE on August 11. On August 19, a short-lived explosion sent ash to $9 \mathrm{~km}(30,000 \mathrm{ft})$ where it drifted as far as
1,300 km (800 mi) to the west over the Kamchatka Peninsula and Sea of Okhotsk. To our knowledge, no disruption of air traffic resulted. Activity decreased rapidly and KVERT downgraded the volcano to YELLOW on August 21.

During periods of elevated eruptive activity at adjacent Klyuchevskoy Volcano in late 2008, it was impossible to discern the state of Bezymianny seismicity. Based on other observations, the volcano remained in a low state of unrest through the end of the year. No further explosions or hot avalanches were noted, although a thermal anomaly was occasionally visible in satellite images.

On March 30, 1956, Bezymianny’s only historic eruption began with a catastrophic flank failure, debris avalanche, and lateral blast (Bogoyavlenskaya and others, 1985). Since then, lava extrusion has produced a dome that periodically collapses or produces powerful vertical ash emission events, pyroclastic flows and short-lived but far-traveled ash clouds (Girina and others, 1993; Carter and others, 2007). 


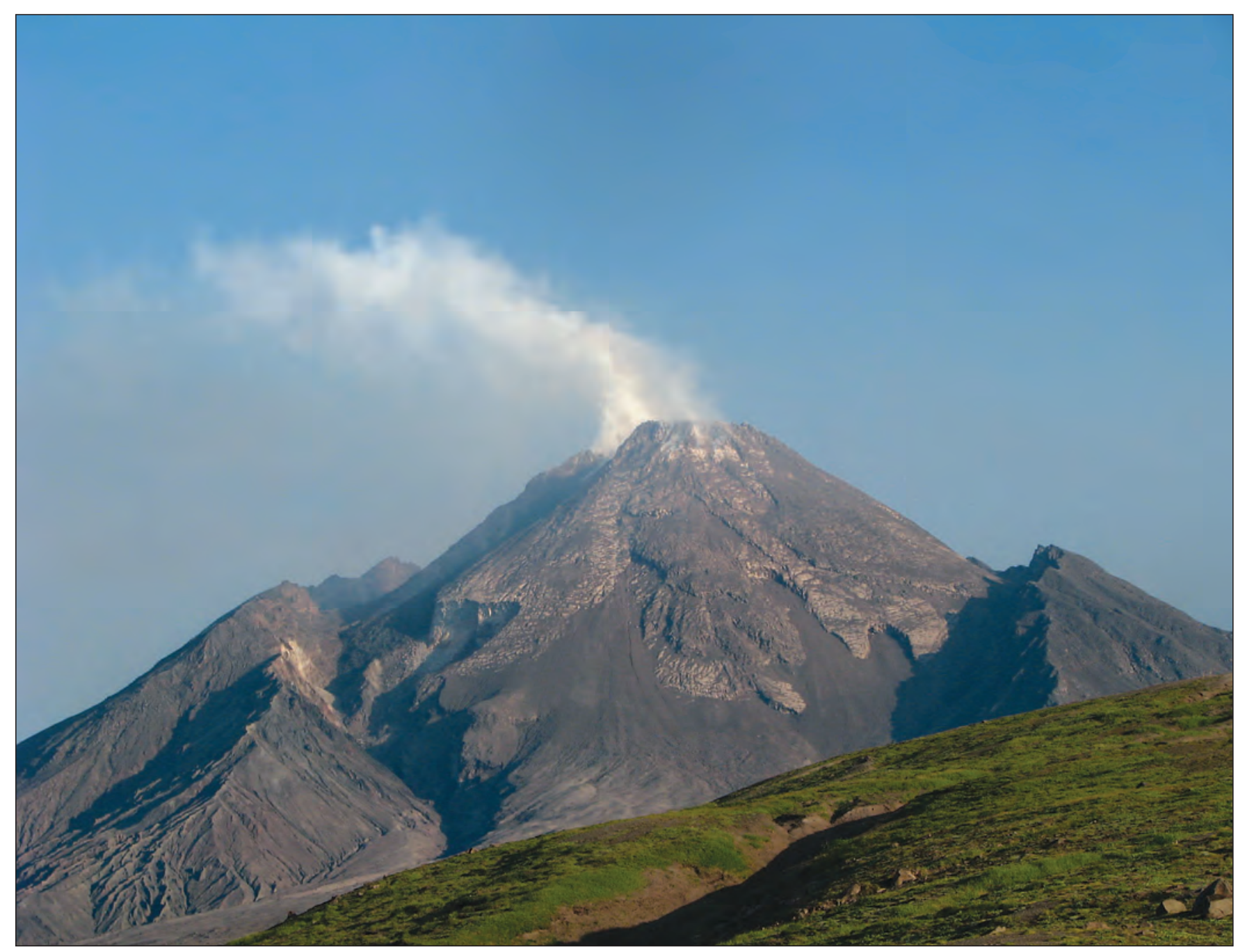

Figure 41. View of the west flank of Bezymianny Volcano on July 20, 2008. Photograph by 0. Girina, IVS/KVERT. 


\section{Karmsky Volcano}

CAVW\# 1000-13=

$54^{\circ} 03^{\prime} \mathrm{N} 159^{\circ} 27^{\prime} \mathrm{W}$

$1,486 \mathrm{~m}(4,876 \mathrm{ft})$

Kamchatka Peninsula, Russia

STROMBOLIAN / VULCANIAN ERUPTION CONTINUES INTERMITTENTLY

Explosions, low-level ash clouds

Karymsky Volcano has been in nearly constant eruption since the beginning of 1996, but 2008 was a quieter year than most for this active, remote Kamchatkan volcano. The end of 2007 had seen a decrease in the vigor and frequency of explosive events from Karymsky, and this continued in early 2008. Seismicity was commonly reported to be at or slightly above background and nothing anomalous was seen in satellite imagery. Brief interruptions in seismic-data telemetry occurred several times in January, March, November, and December.

The volcano remained active, however, and in satellite imagery throughout the year, fresh ash deposits were occasionally visible extending from the volcano. A weak thermal anomaly also was intermittently visible although the volcano was frequently obscured by clouds.

Seismicity increased in mid-March and mostly lowlevel $[<3 \mathrm{~km}(10,000 \mathrm{ft})]$ ash emissions and ash deposits were confirmed in satellite data. KVERT elevated the Level of Concern Color Code to ORANGE on March 13. Pilots reported ash reaching $7 \mathrm{~km}$ (23,000 ft) in late March and the size of the thermal anomaly detected in satellite was consistent with an increase in eruptive intensity. Bursts of ash produced spokes of ash-fall deposits extending to the east, south, and southwest of the volcano. One ash cloud visible in satellite imagery on April 1 extended about $110 \mathrm{~km}(68 \mathrm{mi})$ south from Karymsky. Seismicity suggested ongoing intermittent explosions and or hot avalanches through the spring.
After 3 months of moderate explosive activity, unrest diminished in June and KVERT downgraded Karymsky to YELLOW on June 26 but back to ORANGE on July 24 as activity intensified again. During this entire time, seismicity was consistent with weak to moderate explosions (fig. 42). A weak thermal anomaly persisted in satellite data. Most of these events produced ash clouds below about $5 \mathrm{~km}(16,000 \mathrm{ft})$ ASL and few clouds were tracked more than $100 \mathrm{~km}$ (62 mi) downwind. Karymsky remained at this low to moderate level of explosive activity through the end of the year.

Karymsky is the most active volcano on the Kamchatkan Peninsula. Explosive and effusive-explosive eruptions of andesitic tephra and lava flows alternating with periods of repose are typical of Karymsky (Ivanov and others, 1991). The current phase of unrest began in mid-April 1995 with increasing seismicity and culminated in an explosive eruption that began on January 1, 1996. Initial eruptive activity occurred simultaneously at Karymsky Volcano and from a vent at the north edge of Karymsky Lake a distance of about $10 \mathrm{~km}$ (6.2 mi; Fedotov, 1998; Belousov and Belousova, 2001). Since then, periods of explosive eruptions of ash and blocks have alternated with periods of lava-flow production. 


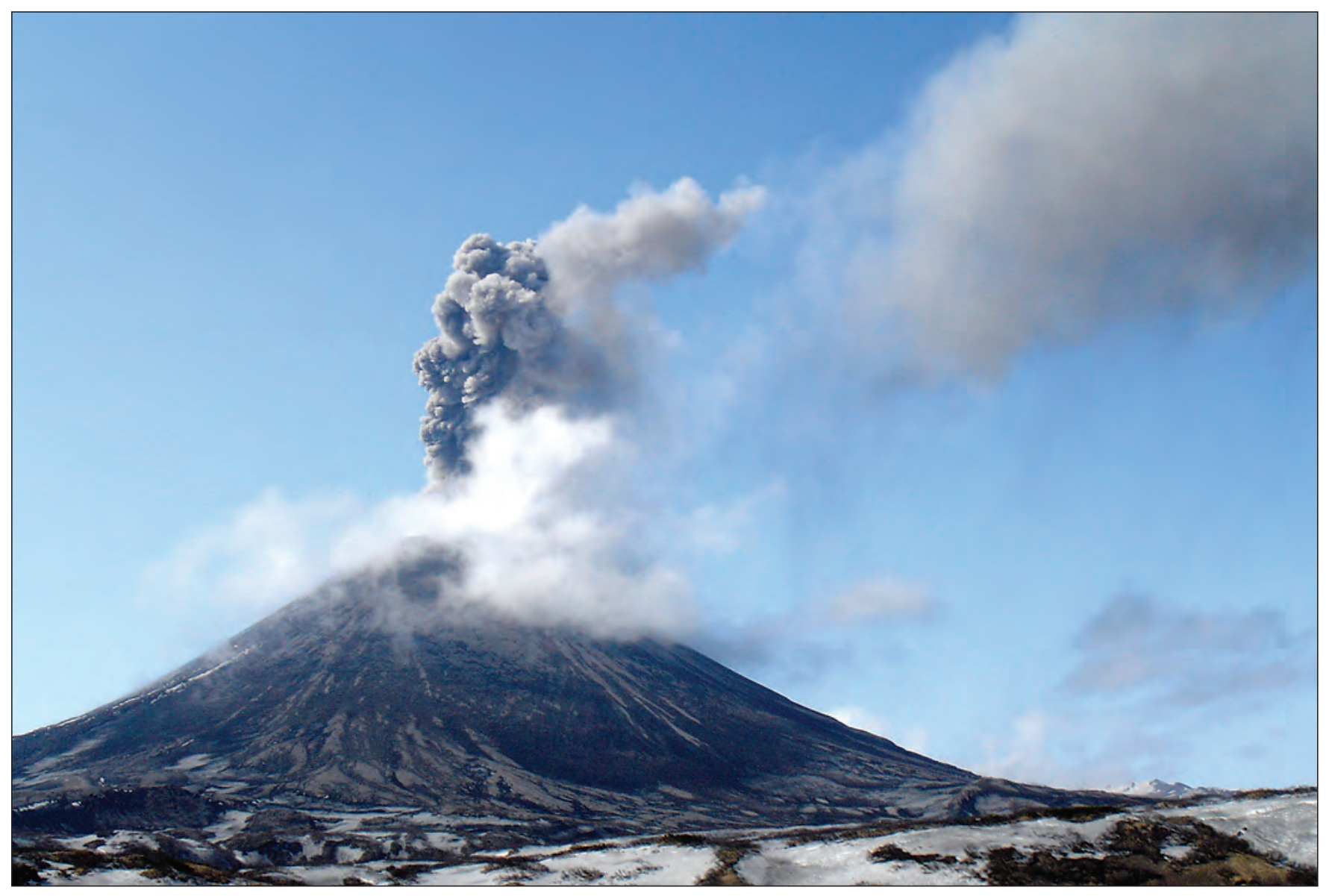

Figure 42. Typical explosive activity at Karymsky Volcano on April 23, 2008. The ash plume rises about $800 \mathrm{~m}(2,600 \mathrm{ft})$ above the volcano's summit. Photograph by A. Manvich, IVS/KVERT. 


\section{Koryaksky Volcano}

CAVW\# 1000-09=

$53^{\circ} 19^{\prime} \mathrm{N} 158^{\circ} 43^{\prime} \mathrm{W}$

$3,456 \mathrm{~m}(11,339 \mathrm{ft})$

Kamchatka Peninsula, Russia

INCREASED FUMAROLIC OUTPUT, PHREATIC EXPLOSIONS

Minor ash fall, plumes on satellite imagery

On December 24, 2008, about 1 month after a slight increase in background seismicity and visible fumarolic output, KVERT reported a moderate explosive eruption from the active fumarole on the northwest flank of Koryaksky Volcano. A distinctive plume was visible in satellite images extending $140 \mathrm{~km}$ (87 mi) northeast from the volcano. The ash cloud was about $4 \mathrm{~km}(13,000 \mathrm{ft})$ ASL. A dark, ash-rich column was reported rising up to $300 \mathrm{~m}(1,000 \mathrm{ft})$ above the fumarole by observers in Nalychevo Valley north of the volcano and ash fall was reported in the vicinity of the volcano. These same observers also reported hearing a 'boom' on the night of December 23-24.

On December 26 and 28, photographs of the volcano taken from several vantage points show a distinct ash-bearing plume emanating from the northwest flank of the volcano (fig. 43). KVERT issued an Information Release and raised the Level of Concern Color Code for Koryaksky from GREEN to ORANGE. Enhanced fumarolic activity continued into the first weeks of 2009, however, no significant increase in shallow seismicity was detected.

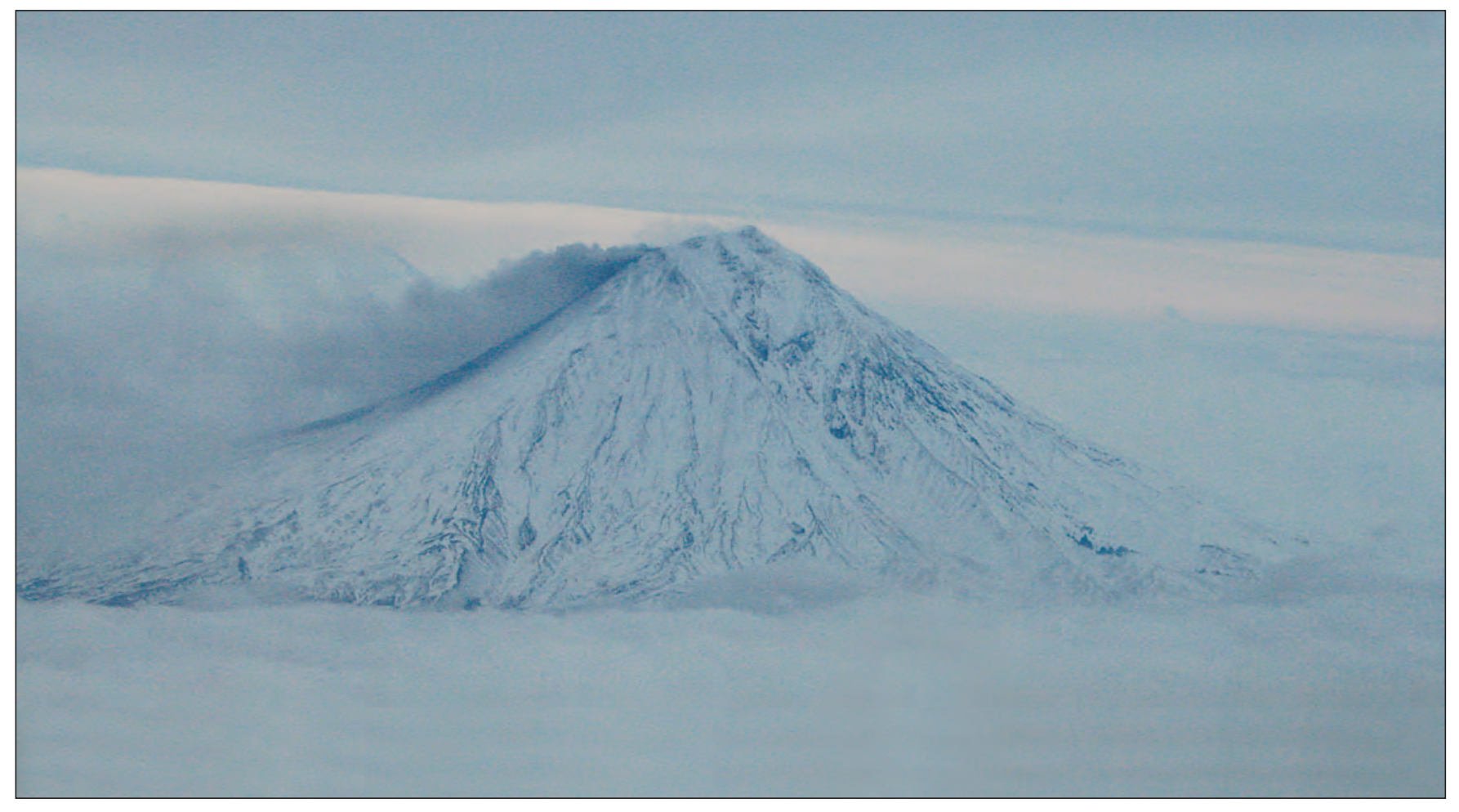

Figure 43. Ash cloud and deposits of ash on the northwestern flank of Koryaksky Volcano, December 26, 2008. View is to the north. Photograph by S. Ruchagova, IVS. 
The large eroded, rugged Koryaksky stratovolcano looms about 10 km (6.2 mi) outside Kamchatka’s largest city, Petropavlovsk and the International Airport at Yelizovo (fig. 44). There is no historical record of significant explosive eruptions, and the 1957 eruption account of a VEI 3 event with a lava flow (Siebert and Simkin, 2002-) is not supported by more recent work (O. Girina, KVERT, written commun., 2008). Similarly, the reported 1895-1896 eruption was later reinterpreted as a phreatic explosion and fumarolic activity (Meleketsev, 1996). A vigorous permanent fumarole-the area active during 2008 and into 2009-exists high on the northwest flank of the volcano. Holocene lavas are present on the west and southwest flanks; lahars associated with activity several thousand years ago reached Avacha Bay (Siebert and Simkin, 2002).

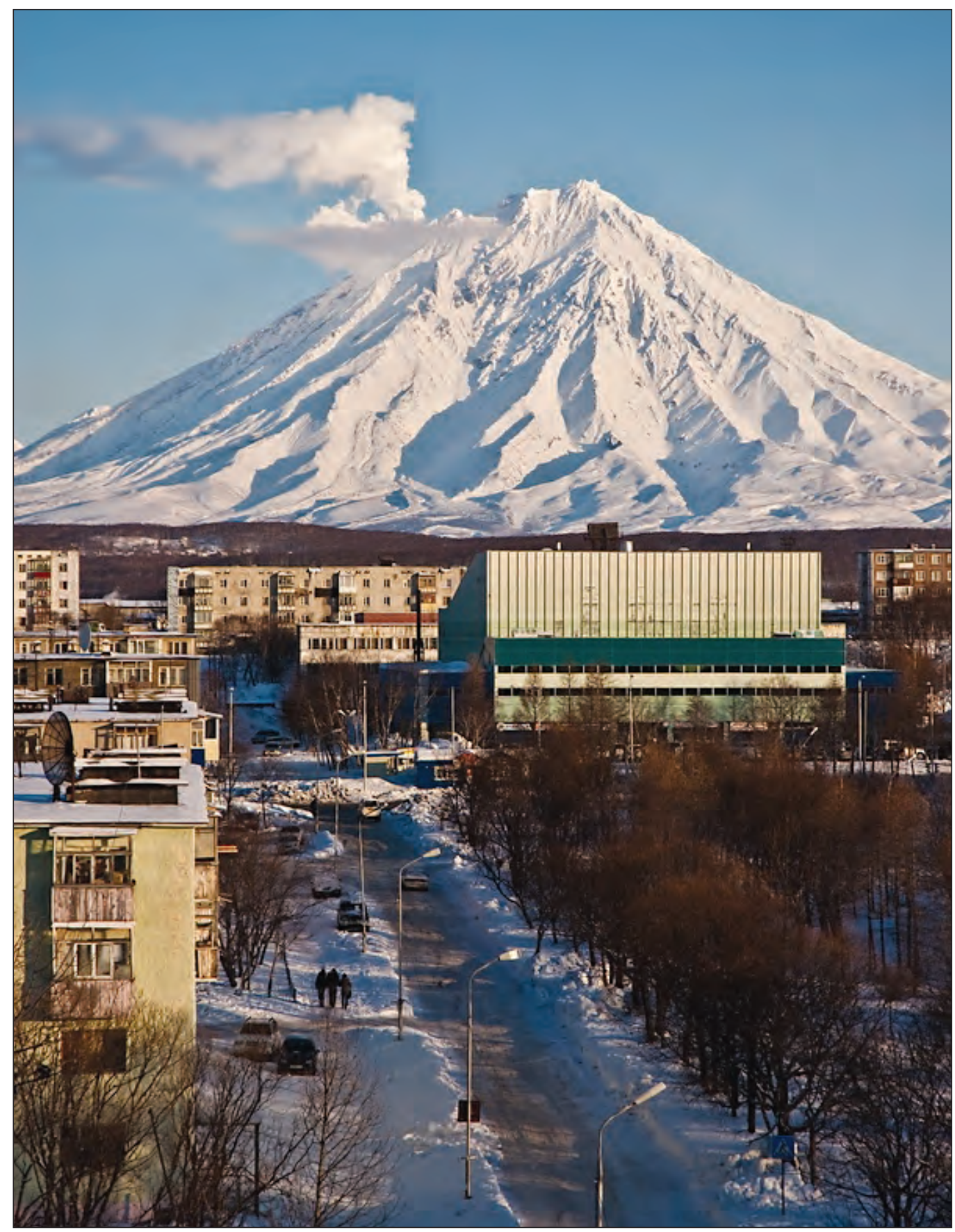

Figure 44. Vigorous fumarolic plume reaching about $4.5 \mathrm{~km}$ ASL (14,800 ft) from Koryaksky Volcano as seen from the Institute of Volcanology and Seismology in Petropavlovsk on January 10, 2009. View is to the north. Photograph by D. Melnikov, IVS/KVERT. 


\begin{tabular}{|l|l|}
\hline Gorely Volcano & Mutnovsky Volcano \\
CAVW\# $1000-07=$ & CAVW\# $1000-06=$ \\
$52^{\circ} 33^{\prime} \mathrm{N} 158^{\circ} 02^{\prime} \mathrm{E}$ & $52^{\circ} 27^{\prime} \mathrm{N} 158^{\circ} 12^{\prime} \mathrm{E}$ \\
$1,829 \mathrm{~m}(6,001 \mathrm{ft})$ & $2,323 \mathrm{~m}(7,621 \mathrm{ft})$ \\
\hline $\begin{array}{l}\text { Kamchatka Peninsula, Russia } \\
\text { INCREASED SEISMICITY } \\
\text { No eruption }\end{array}$ \\
\hline
\end{tabular}

KVERT reported an increase in seismicity in the vicinity of Gorely and Mutnovsky Volcanoes located about $75 \mathrm{~km}$ (47 mi) southwest of Petropavlovsk, on December 24, 2007. Initial analysis suggested the source was likely Gorely, which also appeared to have increased its fumarolic output coincident with the rise in seismicity, and KVERT raised the Level of Concern Color Code to YELLOW for both volcanoes. Because of the proximity of the volcanoes to each other [the two summits are about $16 \mathrm{~km}(10 \mathrm{mi})$ apart] and limited seismic data, KBGS scientists were unable to verify which volcano was the source of the increased seismicity. After several weeks of no further unrest, KVERT reverted to GREEN for both volcanoes on January 10, 2008.

However, on June 13, after 1 month of slowly increasing seismicity and the onset of volcanic tremor on the single seismic station near the two volcanoes, KVERT returned to YELLOW for both volcanoes out of concern for the unrest. No unusual surface manifestation of this increase in seismicity was noted, and KVERT reinstated GREEN on June 19 after no further escalation of unrest. A mild and typical fumarolic plume emanated from the very active geothermal fields of both volcanoes.
Mutnovsky Volcano is considered one of the most active volcanoes of southern Kamchatka. It is composed of four overlapping stratovolcanoes, the youngest of which is early Holocene in age. Simkin and Siebert (1994) list 11 eruptions in the 20th century, most of which were small phreatic explosions except for a lava-flow producing event in 1904. A commercial power plant, Mutnovsky Geothermal Power Station, produces electricity for the area.

Gorely Volcano consists of a complex set of five overlapping stratovolcanoes within late Pleistocene caldera Simkin and Siebert (1994). Many of the several dozen flank craters contain lakes. Historical eruptions have been dominated by Vulcanian and Phreatic explosions; Siebert and Simkin (2002) list 13 possible eruptions since about 1700, the most recent in 1986. 


\section{Chikurachki Volcano}

CAVW\# 0900-36=

$50^{\circ} 19^{\prime} \mathrm{N} 155^{\circ} 28^{\prime} \mathrm{W}$

$1,816 \mathrm{~m}(5,958 \mathrm{ft})$

Paramushir Island, Russia

MODERATE ASH EXPLOSIONS AND CLOUDS IN JULY

Chikurachki Volcano had last produced intermittent, low ash clouds in spring and summer of 2007, but entered 2008 quietly at Level of Concern Color Code GREEN.

On July 29, a weak ash plume was detected in MODIS imagery extending more than $30 \mathrm{~km}$ (19 mi) westsouthwest from the volcano and KVERT elevated the Level of Concern Color Code to YELLOW. Eruptive activity continued producing several ash plumes and on July 31, KVERT declared ORANGE noting that the ash cloud may have reached about $6 \mathrm{~km}(20,000 \mathrm{ft})$ ASL. Over the next month, most satellite views of the volcano were cloudy, and information about activity at the volcano-primarily low level fumarolic plumes and occasional ash-bearing clouds (fig. 45) — was only available intermittently from local scientific observers. KVERT reverted to YELLOW on August 28 and GREEN on September 18.
Chikurachki is the highest volcano on Paramushir Island (fig. 37) and it has been frequently active in the last several years with intermittent, low-level ash clouds reaching at most about 6 km ASL (20,000 ft; McGimsey and others, 2007, McGimsey and others, 2005). Direct information about the volcano is limited and intermittent because it is not monitored seismically, and few people live nearby in the community of Podgorny, $25 \mathrm{~km}$ (15 mi) from the volcano. Several IVS scientists are stationed in Podgorny report occasional observations of activity at Chikurachki and nearby Ebeko. Situated $105 \mathrm{~km}$ (65 mi) southwest of the tip of the Kamchatkan Peninsula, Chikurachki is a distinctive cone with a mantle of red, oxidized basaltic andesite scoria on its upper flanks (Gorshkov, 1970; Simkin and Siebert, 1994). There are at least six known historical eruptions attributed to Chikurachki, including a VEI 4 eruption in 1986 (Belousov and others, 2003).

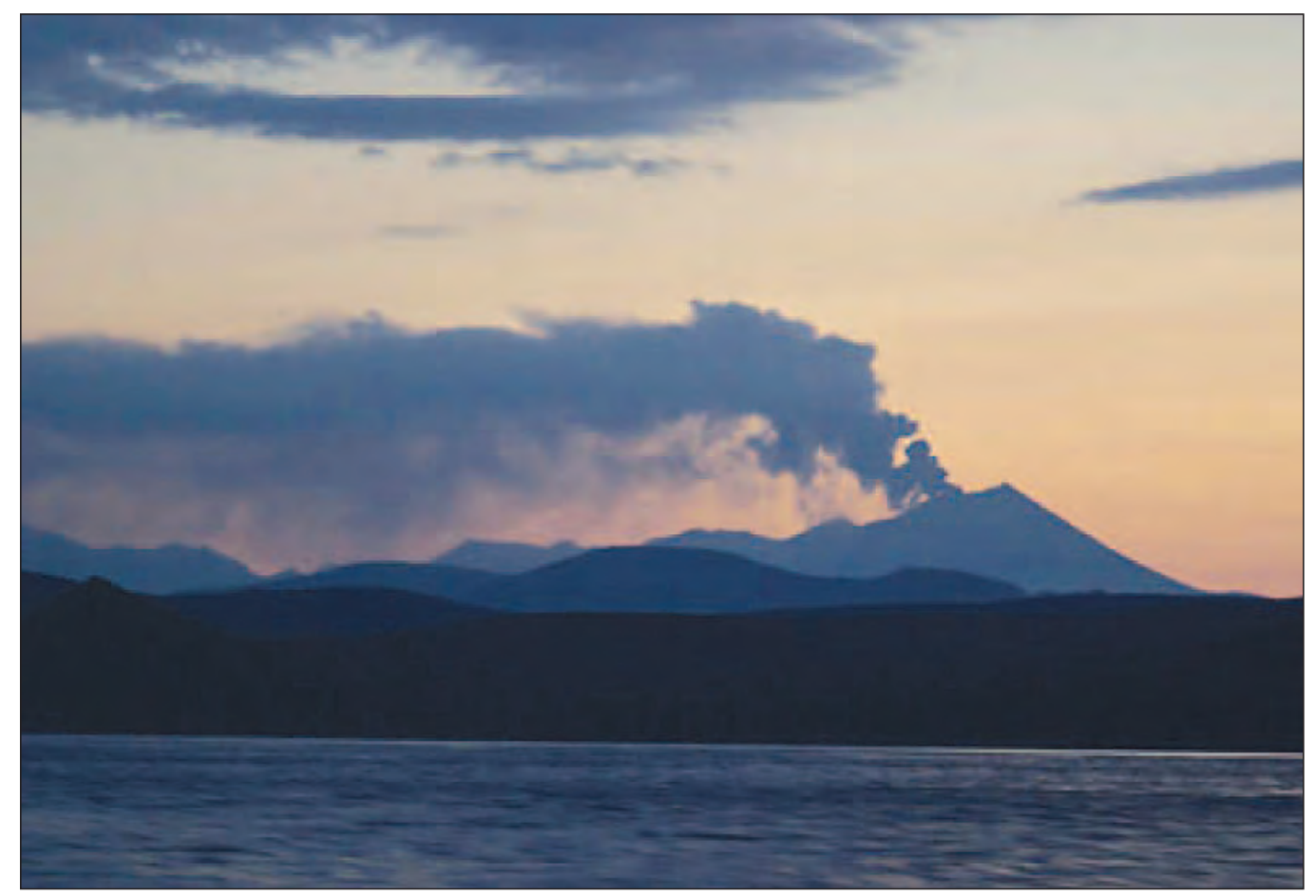

Figure 45. An ash and gas cloud drifting to the southeast from Chikurachki Volcano on August 2, 2008. A curtain of ash can be seen falling from the cloud. Photograph by A.K. Gruzevich, Russian Federal Research Institute of Fisheries and Oceanography. 


\title{
Volcanic Activity, Central and Southern Kurile Islands
}

The Institute of Marine Geology and Geophysics (IMGG), the host institute for the Sakhalin Volcanic Eruption Response Team (SVERT; Rybin and others, 2004; Neal and others, 2008), reports on activity at Kurile Island volcanoes. SVERT uses twice-daily MODIS and other satellite imagery of the Kurile Islands, periodic (every 10 days) reports of seismic data from Kunashir and Iturup Islands, and visual observations from several southern Kurile Islands. By agreement between SVERT and KVERT, the northernmost Kurile Islands of Paramushir and Alaid are under the reporting jurisdiction of KVERT.

2008 was another quiet year for Kurile Island volcanoes. A brief episode of increased fumarolic output at Tyatya Volcano on Kunashir Island was the only possible event of note.

\author{
Tyatya Volcano \\ CAVW\# 0900-03= \\ $44^{\circ} 27^{\prime} \mathrm{N} 146^{\circ} 15^{\prime} \mathrm{W}$ \\ $1,819 \mathrm{~m}(5,968 \mathrm{ft})$ \\ Kunashir Island, southern Kurile Islands, Russia \\ INCREASED FUMAROLIC OUTPUT \\ No eruption
}

On February 7, SVERT was contacted by colleagues on Kunashir Island regarding an increase in fumarolic output from Tyatya Volcano (fig. 46). No plume or other anomalous activity was detected on subsequent MODIS satellite passes and the activity apparently diminished rapidly to background. SVERT did not issue any formal information release. Seismicity on regional stations detected no volcano-related activity.

Tyatya Volcano consists of a central stratocone situated within an older caldera (fig. 47; Gorshkov, 1970; Rybin and others, 2004). The inner cone has a basal diameter of $1,500 \mathrm{~m}$ $(4,900 \mathrm{ft})$ and a height of about $400 \mathrm{~m}(1,300 \mathrm{ft})$ from the floor of the caldera to the southeastern rim of the cone, the highest point on the volcano. Many lava flows extend down the flanks of the cone and have filled and overflowed the southwestern part of the caldera, reaching as much as $9 \mathrm{~km}$
(5.6 mi) in length. Scoria covers much of the central cone, the caldera floor, and the outer flanks. The lava flows and scoria are basaltic in composition (Gorshkov, 1970). An explosive eruption in 1973 produced two maar craters, named Volodavets and Radkevich, on the eastern flank of the volcano (Smithsonian Institution, 1973).

Historical eruptions of Tyatya occurred in 1812 and 1973. The 1812 eruption was an explosive VEI 2 event (Siebert and Simkin, 2002-). The 1973 eruption was preceded by strong earthquakes and occurred from a flank vent on the eastern side of the volcano (Smithsonian Institution, 1973; Siebert and Simkin, 2002-). Clouds of steam rising from the summit of Tyatya were observed in 1978, 1981, and 1982 (Smithsonian Institution, 1978, 1981, 1988). Rybin and others (2004) have reported weak fumarolic and thermal activity in the central crater of Tyatya Volcano. 


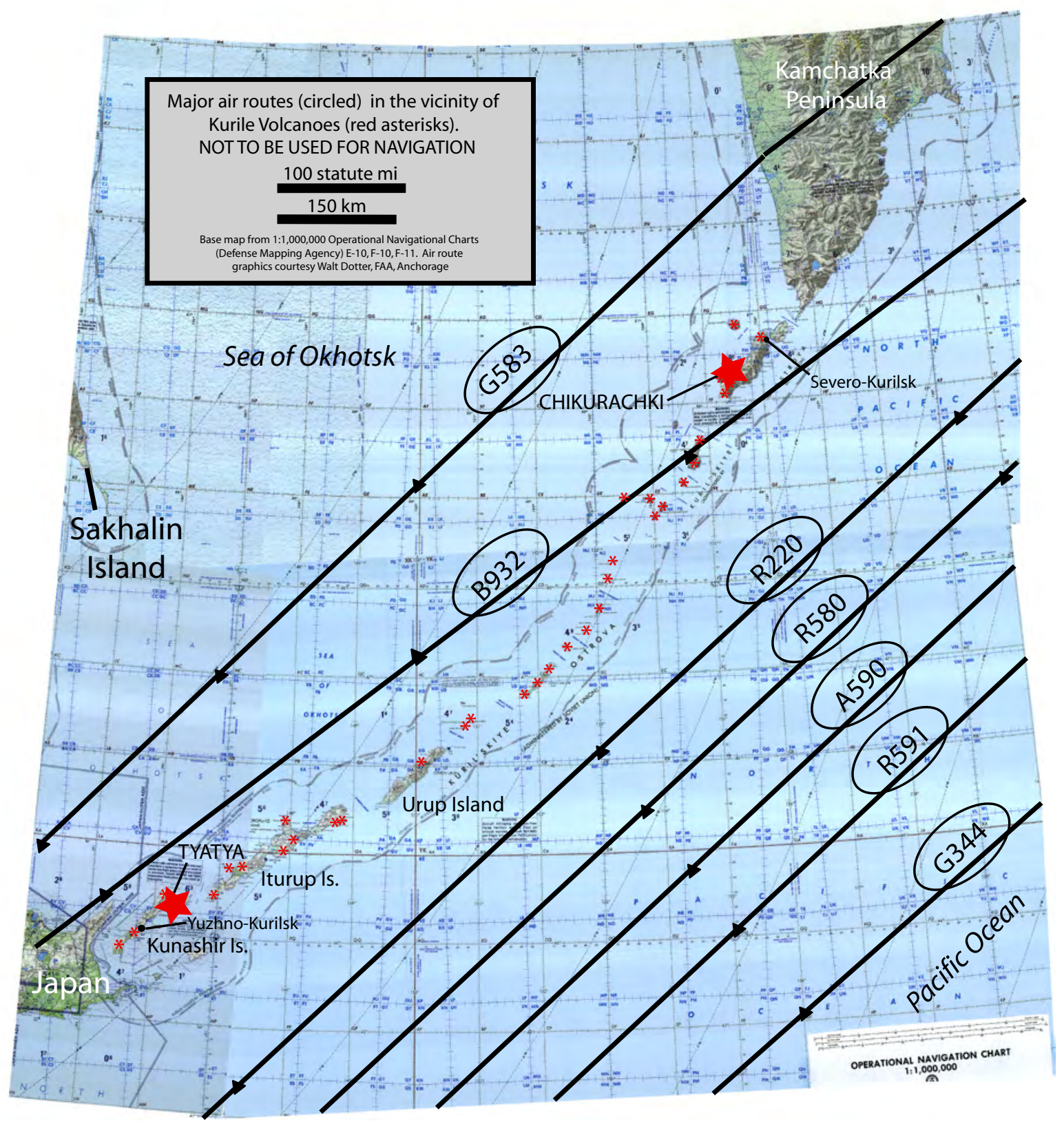

Figure 46. Kurile Island Volcanoes with place names used in this report. Volcanoes mentioned in this report are shown by large stars, additional volcanoes shown by red asterisks. Bold black lines are fixed air routes (route identifiers are circled) in the North Pacific and Russian Trans East systems. Black triangles are air navigational fixes. (From Neal and others, 2008.) 


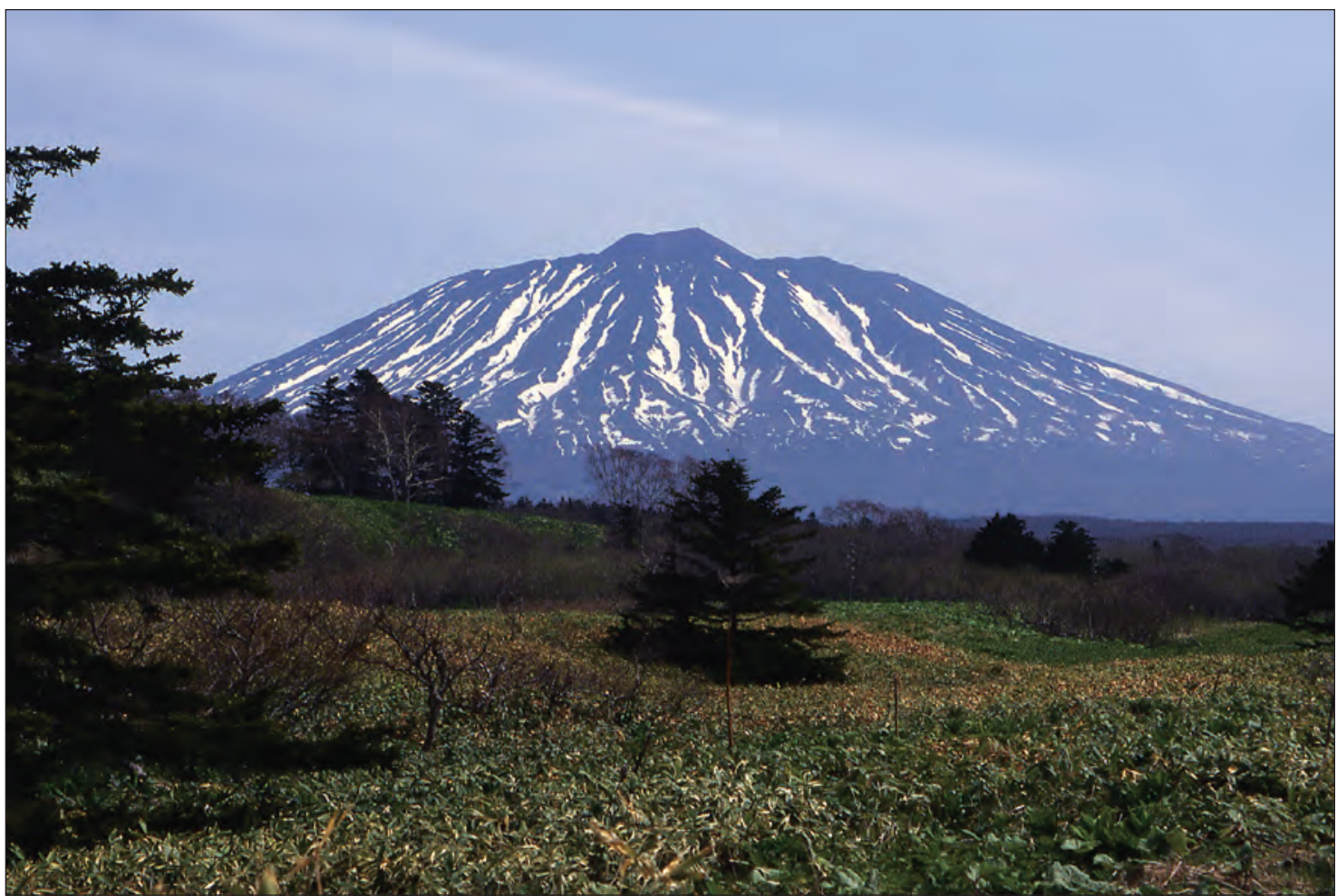

Figure 47. Fumarolic activity at Tyatya Volcano. View of the southwest flank. A fumarolic plume rises about $300-500 \mathrm{~m}(1,000-1,600 \mathrm{ft})$ above the summit of the volcano, February 7, 2008. Photograph by N.A. Eremenko, Kuril National Park, used with permission.

\section{Summary}

2008 was an extremely busy year for the Alaska Volcano Observatory. Two significant explosive eruptions in the Aleutian Islands - including the first largely hydrovolcanic eruption in the U.S. since 1977 at Okmok Volcanodominated AVO's response efforts and subsequent scientific focus. AVO staff maintained 24-hour, 7-day per week staffing at the Observatory for more than 1 month during the two eruptions. Both eruptions underscored the continuing challenge of correctly recognizing eruption precursors, rapid verification of eruption onset, and tracking and forecasting far-traveled ash and aerosol clouds. Both eruptions also had small but documented impacts on the marine community, which has prompted further interagency discussion and planning for more effective marine warnings during future explosive eruptions in the United States (Neal and others, 2009b).

In addition to responding to these two significant eruptions, AVO managed unrest and issued eruption hazard warnings for activity at five other Alaskan volcanoes. Multiple eruptive events from ongoing eruptions at several Kamchatkan volcanoes and one northern Kurile volcano sent ash repeatedly into or near the heavily traveled North Pacific and Russian Trans-East air routes, however, no aircraft encounters occurred.

\section{Acknowledgments}

This report represents work of the Alaska Volcano Observatory staff, colleagues from other USGS Volcano Observatories, cooperating State and Federal agencies, and members of the public. Russian volcanic activity is documented by many scientists at the Institute of Volcanology and Seismology, the Kamchatkan Branch of Geophysical Surveys, and the Institute of Marine Geology and Geophysics. Chad Hults and Andrew Grosz kindly shared their spectacular documentation of Okmok Volcano in eruption. We would like to specifically acknowledge the ongoing contributions of colleagues at Alaska Division of Geological and Geophysical Surveys for design and maintenance of the Alaska Volcano Observatory logs and image database, both priceless tools for review of activity through the year. Technical reviews by Jeff Wynn and Chris Waythomas significantly improved the content and presentation. 


\section{References Cited}

Bacon, C.R., Sisson, T.W., and Mazdab, F.K., 2007, Young cumulate complex beneath Veniaminof caldera, Aleutian arc, dated by zircon in erupted plutonic blocks: Geology, v. 35, no. 6, p. 491-494, doi: 10.1130/G23446A.1.

Beget, J.E., Larsen, J.F., Neal, C.A., Nye, C.J., and Schaefer, J.R., 2005, Preliminary volcano-hazard assessment for Okmok Volcano, Umnak Island, Alaska: Alaska Division of Geological and Geophysical Surveys Report of Investigation 2004-3, 32 p., 1 sheet, scale 1:150,000.

Belousov, A., and Belousova, M., 2001, Eruptive process, effects and deposits of the 1996 and the ancient basaltic phreatomagmatic eruptions in Karymskoye lake, Kamchatka, Russia, in White, J.D., and Riggs, N.R. (eds.), Lacustrine Volcanoclastic Sedimentation: Special Publications of the International Association of Sedimentologists, v. 30, p. 35-60, accessed July 6, 2010, at at http://www.kscnet.ru/ivs/lavdi/staff/belousov/lake.pdf.

Belousov, A., Belousova M., Grishin S.Yu., Krestov P.V., 2003, Historical eruptions of Chikurachki volcano (Paramushir Island, Kuriles): Volcanology and Seismology, v. 3, p. 15-34 (in Russian).

Bogoyavlenskaya, G.E., Braitseva, O.A., Melekestsev, I.V., Kiriyanov, V.Yu., and Miller, C.D., 1985, Catastrophic eruptions of the directed-blast type at Mount St. Helens, Bezymianny and Shiveluch Volcanoes: Journal of Geodynamics, v. 3, issues 3-4, p. 189-218.

Buchheit, R.M., and Ford, J.C., 2008, Biological monitoring in the central Aleutian Islands, Alaska in 2008: Summary Appendices: U.S. Fish and Wildlife Service Report, AMNWR 08/12. Homer, Alaska, 141 p.

Bull, K.F., 2009, Redoubt Volcano: 2009 eruption overview [abs.]: Eos, Transactions of the American Geophysical Union, v. 90, no. 52, Fall Meeting Supplement, Abstract V51F-01.

Byers, F.M. Jr., 1959, Geology of Umnak and Bogoslof Islands, Aleutian Islands, Alaska, in Investigations of Alaskan volcanoes: U.S. Geological Survey Bulletin B 1028-L, p. 267-369, 5 sheets, scale 1 at 1:63,360, 1 at $1: 96,000$, and 1 at 1:300,000.

Cameron, C.E., Nye, C.J., and Neal, C.A., 2008, Counting Alaskan Volcanoes: Eos, Transactions of the American Geophysical Union, v. 89, no. 53, Fall Meeting Supplement, Abstract V43H-07.

Carter A.J., Ramsey, M.S., and Belousov, A.B., 2007, Detection of a new summit crater on Bezymianny Volcano lava dome: Satellite and field-based thermal data: Bulletin of Volcanology, doi: 10.1007/s00445-007-0113-x.
Dean, K.G., Dehn, Jonathan, Papp, K.R., Smith, Steve, Izbekov, Pavel, Peterson, Rorik, Kearney, Courtney, and Steffke, Andrea, 2004, Integrated satellite observations of the 2001 eruption of Mt. Cleveland, Alaska: Journal of Volcanology and Geothermal Research, v. 135, p. 51-73.

Dehn, Jonathan, Dean, K.G., Engle, Kevin, and Izbekov, Pavel, 2002, Thermal precursors in satellite images of the 1999 eruption of Shishaldin Volcano: Bulletin of Volcanology, v. 64, no. 8, p. 525-534.

Dixon, J.P., and Stihler, S.D., 2009, Catalog of earthquake hypocenters at Alaskan volcanoes: January 1 through December 31, 2008: U.S. Geological Survey Data Series 467, 88 p. (Also available at http://pubs.usgs.gov/ds/467/.)

Dreher, S.T., Eichelberger, J.C., and Larsen, J.F., 2005, The petrology and geochemistry of the Aniakchak calderaforming ignimbrite, Aleutian Arc, Alaska: Journal of Petrology, v. 46, no. 9, p. 1747-1768, doi: 10.1093/ petrology/egi032.

Fedotov, S.A., 1998, The 1996 eruption in the Karymsky volcanic center and related events: Special issue of Volcanology and Seismology, v. 19, no. 5, p. 521-767.

Fournier, Tom, Freymueller, Jeff, and Cervelli, Peter, 2009, Tracking magma volume recovery at Okmok volcano using GPS and an unscented Kalman filter: Journal of Geophysical Research, v. 114, B02405, 18 p., doi:10.1029/2008JB005837.

Gardner, C.A., and Guffanti, M.C., 2006, U.S. Geological Survey's alert notification system for volcanic activity: U.S. Geological Survey Fact Sheet 2006-3139, 4 p. (Also available at http://pubs.usgs.gov/fs/2006/3139/.)

Girina, O.A., Bogoyavlenskaya, G.E., and Demyanchuk, Yu.V., 1993, Bezymianny eruption of August 2, 1989: Volcanology and Seismology, v. 15, no. 2, p. 135-144 (in Russian).

Gorshkov, G.S., 1970, Catalog of the active volcanoes of the world including solfatara fields. Part VII. Kurile Islands: International Volcanology Association, Via Tasso 199, Napoli, Italy, 99 p.

Grewingk, Constantine, 1850, Grewingk’s geology of Alaska and the Northwest Coast of America [edited by Marvin W. Falk, translation by Fritz Jaensch published 2003]: Rasmuson Library Historical Translation Series 11, Fairbanks, AK, The University of Alaska Press, 242 p.

Guffanti, M., Schneider, D.J., Wallace, K.L., Hall, T., Bensimon, D.R., and Salinas, L.J., 2010, Aviation response to a widely dispersed volcanic ash and gas cloud from the August 2008 eruption of Kasatochi, Alaska, USA: Journal of Geophysical Research, v. 115, doi:10.1029/2010JD013868, accessed January 3, 2011, at http://www.agu.org/pubs/crossref/2010/2010JD013868. shtml. 
Ivanov, B.V., Braitseva, O.A., and Zubin, M.I., 1991, Karymsky Volcano, chapter 21, in Fedotov, S.A., and Masurenkov, Yu.P. (eds.), Active volcanoes of Kamchatka, Moscow: Nauka Publishers (Moscow), v. 2, p. 202-203.

Izbekov, P.E., 2008, Petrology of the 2008 eruption of Kasatochi volcano, Alaska: Eruption: Eos, Transactions of the American Geophysical Union, v. 89, no. 53, Fall Meeting Supplement, Abstract V53B-0263.

Izbekov, P.E., Sisson, T.W., Wooden, J.L., and Bacon, C.R., 2009, 2008 Kasatochi Eruption: SHRIMP constraints on concentration of volatiles in melt inclusions: Transactions of the American Geophysical Union, v. 90, no. 52, Fall Meeting Supplement, Abstract V51E-1775.

Khrenov, A.P., Dvigalo, V.N., Kirsanov, I.T., Fedotov, S.A., Gorel'chik, I., and Zharinov, N.A., 1991, Klyuchevskoy Volcano, chapter 6, in Fedotov, S.A., and Masurenkov, Yu.P. (eds.), Active volcanoes of Kamchatka, Moscow: Nauka Publishers (Moscow): v. 1, p. 146-163.

Kirianov, V.Yu., Neal, C.A., Gordeev, E.I., and Miller, T.P., 2002, Kamchatkan Volcanic Eruptions Response Team (KVERT): U.S. Geological Survey Fact Sheet 064-02, 2 p., in English and Russian. (Also available in English at http:// pubs.usgs.gov/fs/2002/fs064-02/fs064-02.pdf.)

Larsen, J., Neal, C., Webley, P., Freymueller, J., Haney, M., McNutt, S., Schneider, D., Prejean, S., Schaefer, J., and Wessels, R., 2009, Eruption of Alaska volcano breaks historic pattern: Eos, Transactions of the American Geophysical Union, v. 90, no. 20, p. 173-174.

Lu, Zhong, 2007, InSAR imaging of volcanic deformation over cloud-prone areas - Aleutian Islands: Photogrammetric Engineering and Remote Sensing, v. 73, no. 3, p. 245-257.

Lu, Zhong, Masterlark, Timothy, and Dzurisin, Daniel, 2005, Interferometric synthetic aperture radar study of Okmok volcano, Alaska, 1992-2003: Magma supply dynamics and postemplacement lava flow deformation: Journal of Geophysical Research, v. 110, no. B02210, 18 p., doi: 10.1029/2004JB003148.

McConnell, V.S., Beget, J.E., Roach, A.L., Bean, K.W., and Nye, C.J., 1998, Geologic map of the Makushin volcanic field, Unalaska Island, Alaska: Alaska Division of Geological and Geophysical Surveys Report of Investigations RI 97-20, unpaged, 2 sheets, scale 1:63,360.

McGimsey, R.G., and Neal, C.A., 1996, 1995 Volcanic activity in Alaska and Kamchatka: Summary of events and response of the Alaska Volcano Observatory: U.S. Geological Survey Open-File Report 96-738, 23 p. (Also available at http:// geopubs.wr.usgs.gov/open-file/of96-738/1995 Summary. pdf.)
McGimsey, R.G., Neal, C.A., Dixon, J.P., Malik, Nataliya, and Chibisova, Marina, 2011, 2007 Volcanic activity in Alaska, Kamchatka, and the Kurile Islands: Summary of events and response of the Alaska Volcano Observatory: U.S. Geological Survey Scientific Investigations Report 2010-5242, 112 p. (Also available at http://pubs.usgs.gov/ sir/2010/5242/.)

McGimsey, R.G., Neal, C.A., Dixon, J.P., and Ushakov, Sergey, 2007, 2005 Volcanic activity in Alaska, Kamchatka, and the Kurile Islands: Summary of events and response of the Alaska Volcano Observatory: U.S. Geological Survey Scientific Investigations Report 2007-5269, 94 p. (Also available at http://pubs.usgs.gov/sir/2007/5269/.)

McGimsey, R.G., Neal, C.A., and Girina, Olga, 2005, 2003 volcanic activity in Alaska and Kamchatka: Summary of events and response of the Alaska Volcano Observatory: U.S. Geological Survey Open-File Report 2005-1310, 62 p. (Also available at http://pubs.usgs.gov/of/2005/1310.)

Melekestsev, I.V., 1996, Koryakskiy Volcano, Kamchatka: Eruption of 1895-1896 was a misinterpretation: Volcanology and Seismology, v. 18, p. 237-242.

Miller, T.P., and Chouet, B.A., 1994, The 1989-1990 eruptions of Redoubt volcano: An introduction, in Miller, T.P., and Chouet, B.A., eds., The 1989-1990 eruptions of Redoubt Volcano, Alaska: Journal of Volcanology and Geothermal Research, v. 62, no. 1, p. 1-10.

Miller, T.P., McGimsey, R.G., Richter, D.H., Riehle, J.R., Nye, C.J., Yount, M.E., and Dumoulin, J.A., 1998, Catalog of the historically active volcanoes of Alaska: U.S. Geological Survey Open-File Report 98-582, 104 p. (Also available at http://www.avo.alaska.edu/downloads/catalog.php.)

Miller, T.P., and Smith, R.L., 1987, Late Quaternary calderaforming eruptions in the eastern Aleutian arc, Alaska: Geology, v. 15, no. 5, p. 434-438.

Murray, T.L., and Endo, E.T., 1992, A real-time seismicamplitude measurement system (RSAM): U.S. Geological Survey Bulletin B 1966, p. 5-10.

Neal, C.A., Doukas, M.P., and McGimsey, R.G., 1995, 1994 Volcanic activity in Alaska: Summary of events and response of the Alaska Volcano Observatory: U.S. Geological Survey Open-File Report 95-271, 19 p. (Also available at http://geopubs.wr.usgs.gov/open-file/of95-271/.)

Neal, Christina, Girina, Olga, Senyukov, Sergey, Rybin, Alexander, Osiensky, Jeffrey, Izbekov, Pavel, and Ferguson, Gail, 2009a, Russian eruption warning systems for aviation: Natural Hazards, v. 50, 18 p., doi:10.1007/s11069-0099347-6. 
Neal, C.A., and McGimsey, R.G., 1997, 1996 volcanic activity in Alaska and Kamchatka: Summary of events and response of the Alaska Volcano Observatory: U.S. Geological Survey Open-File Report 97-433, 34 p. (Also available at http:// pubs.er.usgs.gov/djvu/OFR/1997/ofr_97_433.djvu.)

Neal, C.A., McGimsey, R.G., Dixon, J.P., Manevich, Alexander, and Rybin, Alexander, 2009c, 2006 volcanic activity in Alaska, Kamchatka, and the Kurile Islands: Summary of events and response of the Alaska Volcano Observatory: U.S. Geological Survey Scientific Investigations Report 2008-5214, 102 p. (Also available at http://pubs.usgs.gov/sir/2008/5214/.)

Neal, C.A., McGimsey, R.G., and Doukas, M.P., 1996, 1993 volcanic activity in Alaska: Summary of events and response of the Alaska Volcano Observatory: U.S. Geological Survey Open-File Report 96-24, 21 p. (Also available at http://geopubs.wr.usgs.gov/open-file/of96-24/.)

Neal, C.A., McGimsey, R.G., Miller, T.P., Riehle, J.R., and Waythomas, C.F., 2001, Preliminary volcano-hazard assessment for Aniakchak Volcano, Alaska: U.S. Geological Survey Open-File Report 00-0519, 35 p. (Also available at http://geopubs.wr.usgs.gov/open-file/of00-519/.)

Neal, Christina, Rybin, Alexander, Chibisova, Marina, and Miller, Edward, 2008, Active volcanoes of the Kurile Islands: A reference guide for aviation users: U.S. Geological Survey Open-File Report 2008-1162, 10 p.

Neal, Christina, Wallace, Kristi, Waythomas, Chris, Cameron, Cheryl, and Glazewski, Matt, 2009b, Impacts on marine operations during 2008 Aleutian eruptions: towards improving warning messages for vessels at sea: 6th Biennial Workshop on Japan-Kamchatka-Alaska Subduction Processes (JKASP 2009), Geophysical Institute, University of Alaska Fairbanks, Scientific Program and Abstracts, p. 44.

Nicholson, R.S., 2003, The 1931 eruption of Aniakchak volcano, Alaska: University of Alaska Fairbanks, unpublished M.S. thesis, $270 \mathrm{p}$.

Nye, C.J., Keith, T.E.C., Eichelberger, J.C., Miller, T.P., McNutt, S.R., Moran, S., Schneider, D.J., Dehn, J., and Schaefer, J.R., 2002, The 1999 eruption of Shishaldin Volcano, Alaska: monitoring a distant eruption: Bulletin of Volcanology, v. 64, no. 8, p. 507-519.

Ponomareva, V.V., Pevzner, M.M., and Melekestsev, I.V., 1998, Large debris avalanches and associated eruptions in the Holocene eruptive history of Shiveluch Volcano, Kamchatka, Russia: Bulletin of Volcanology, v. 59, no. 7, p. $490-505$.
Reyes, C.G., and McNutt, S.R., 2008, Comparing amplitudebased tremor locations from the July-August 2008 Okmok eruption to 2003-2005 non-eruptive tremor sequences: Eos, Transactons of the American Geophysical Union, v. 89, no. 53, Fall Meeting Supplement, Abstract A53B-0256.

Riehle, J.R., Fleming, M.D., Molnia, B.F., Dover, J.H., Kelley, J.S., Miller, M.L., Plafker, George, and Till, A.B., 1997, Shaded relief image of Alaska: U.S. Geological Survey Miscellaneous Investigations Series MI-2585.

Rybin, A.V., Karagusov, Y.V., Izbekov, Pavel, Terentyev, N.S., Guryanov, V.B., Neal, C.A., and Dean, Ken, 2004, Status of monitoring active volcanoes of the Kurile Islands: Present and future, in Proceedings of the Second International Conference on Volcanic Ash and Aviation Safety. Published by the Office of the Federal Coordinator for Meteorological Services and Supporting Research, p. 61-66.

Schaefer, J.R., Cameron, C.E., and Nye, C.J., 2009, Historically active volcanoes of Alaska: Alaska Division of Geological and Geophysical Surveys Miscellaneous Publication 133, 1 sheet, scale 1:3,000,000, accessed January 3, 2011, at http://www.dggs.dnr.state.ak.us/pubs/ pubs?reqtype $=$ citation $\& I D=20181$.

Scott, W.E., Nye, C.J., Waythomas, C.F., and Neal, C.A., 2010, August 2008 eruption of Kasatochi Volcano, Andreanof Islands, Alaska-Resetting an island landscape: Arctic, Antarctic, and Alpine Research, v. 42, no. 3, p. 250-259.

Searcy, C.K., Dean, K.G., and Stringer, W., 1998, PUFF: A volcanic ash tracking and prediction model: Journal of Volcanology and Geothermal Research, v. 80, p. 1-16.

Siebert, Lee, and Simkin, Tom, 2002-, Volcanoes of the World: An illustrated catalog of Holocene volcanoes and their eruptions: Smithsonian Institution, Global Volcanism Program Digital Information Series, GVP-3, accessed July 6, 2010, at http://www.volcano.si.edu/world/.

Simkin, Tom, and Siebert, Lee, 1994, Volcanoes of the World [2 $2^{\text {nd }}$ ed.]: Tucson, Arizona, Geoscience Press, Inc., 349 p.

Smith, W.H.F., and Sandwell, D.T., 1977, Global seafloor topography from satellite altimetry and ship depth soundings: Science, v. 277, p. 1957-1962.

Smithsonian Institution, 1973, Tiatia: Center for Short Lived Phenomena, Event Notification Report, nos. 92-73.

Smithsonian Institution, 1978, Tiatia: Scientific Event Alert Network Bulletin, v. 3, no. 8.

Smithsonian Institution, 1981, Tiatia:, Scientific Event Alert Network Bulletin, v. 6, nos. 7, 12. 
Smithsonian Institution, 1988, Tiatia: Scientific Event Alert Network Bulletin, v. 13, no. 11.

Vergniolle, S., Boichu, M., and Caplan-Auerbach, J., 2004, Acoustic measurements of the 1999 eruption of Shishaldin Volcano, Alaska: (1) origin of Strombolian activity: in Special issue on conduit processes during explosive basaltic eruptions: Journal of Volcanology and Geothermal Research, v. 137, p. 109-134.

Wallace, K., and Schaefer, J.R., 2009, Timing, distribution, and character of tephra fall from the 2009 eruption of Redoubt Volcano, Alaska, a progress report: Eos, Transactions of the American Geophysical Union, v. 90, no. 52, Fall Meeting Supplement, Abstract V43A-2220.

Waythomas, C.F., Dorava, J.M., Miller, T.P., Neal, C.A., and McGimsey, R.G., 1997, Preliminary volcano-hazard assessment for Redoubt Volcano, Alaska: U.S. Geological Survey Open-File Report 97-857, 40 p., 1 plate.
Waythomas, C.F., Prejean, S.G., and Schneider, D.J., 2008, Small volcano, big eruption, scientists rescued just in time: People, Land \& Water, the U.S. Department of the Interior's employee news magazine.

Waythomas, C.F., Scott, W.E., Prejean, S.G., Schneider, D.J., Izbekov, P., and Nye, C.J., 2010, The 7-8 August eruption of Kasatochi Volcano, central Aleutian Islands, Alaska: Journal of Geophysical Research, v. 115, B00B06, doi:10.1029/2010JB007437.

Zharinov, N.A., Bogoyavlenskaya, G.E., Khubunaya, S.A., and Demyanchuk Yu.V., 1995, A new eruption cycle of Shiveluch Volcano, 1980-1993: Volcanology and Seismology, v. 17, p. 21-30 (in Russian). 
This page is intentionally left blank. 


\section{Glossary of Selected Terms and Acronyms}

AKDGGS: Alaska Division of Geological and Geophysical Surveys.

AKDT: "Alaska Daylight Time"; UTC

-8 hours.

AKST: "Alaska Standard Time"; UTC -9 hours AKST.

andesite: volcanic rock composed of about 53-63 percent silica $\left(\mathrm{SiO}_{2}\right.$; an essential constituent of most minerals found in rocks).

ash: fine fragments (less than $2 \mathrm{~mm}$ across) of lava or rock formed in an explosive volcanic eruption.

ASL: above sea level.

ASTER: Advanced Spaceborne Thermal Emission and Reflection Radiometer.

AVHRR: "Advanced Very High Resolution Radiometer;" AVHRR provides one form of satellite imagery.

AV0: Alaska Volcano Observatory.

basalt: general term for dark-colored igneous rock, usually extrusive, containing about 45-52 weight percent silica $\left(\mathrm{SiO}_{2}\right.$, an essential constituent of most minerals found in rocks).

bomb: boulder-size chunk of partly solidified lava explosively ejected from a volcano.

caldera: a large, roughly circular depression usually caused by volcanic collapse or explosion.

CAVW: Smithsonian Institute's "Catalog of Active Volcanoes of the World" (Simkin and Siebert, 1994).

cinder cone: small, steep-sided conical hill built mainly of cinder, spatter, and volcanic bombs.

COSPEC: "Correlation Spectrometer," a device for measuring sulfur-dioxide emissions.

CWSU: "Center Weather Service Unit" of the National Oceanic and Atmospheric Administration, stationed at the Air Route Traffic Control Center.

ERSDAC: Earth Remote Sensing Data Analysis Center.
FAA: Federal Aviation Administration.

fallout: a general term for debris that falls to the Earth from an eruption cloud.

fault: A fracture along which the blocks of the Earth's crust on either side have moved relative to one another parallel to the fracture.

fissure: a roughly linear or sinuous crack or opening on a volcano; a type of vent which commonly produces lava fountains and flows.

FLIR: "Forward Looking Infrared Radiometer," used to delineate objects of different temperature.

fumarole: a small opening or vent from which hot gases are emitted.

F/N: Fishing Vessel.

GMS: Geostationary Meteorological Satellite.

GMT: Greenwich Mean Time

GOES: Geostationary Operational Environmental Satellite.

GPS: Global Positioning System.

GSFC: Goddard Space Flight Center.

Holocene: geologic epoch extending from the present to 10,000 years ago.

HRPT: High Resolution Picture Transmission.

IMGG: Russian "Institute of Marine Geology and Geophysics."

incandescent: glowing red or orange due to high temperature.

InSAR: Interferometric Synthetic Aperture Radar.

intracaldera: refers to something within the caldera.

ISS: International Space Station.

IVS: Russian "Institute of Volcanology and Seismology."

JAROS: Japan ASTER Science Team.

JMA: Japanese Meteorological Agency.

Ka: thousands of years before the present.

KDT: "Kamchatkan Daylight Time" equals AKDT + 21 hrs. 
KBGS: Kamchatka Branch of Geophysical Surveys.

KEMSD: Russian "Kamchatka Experimental and Methodical Seismological Department."

KST: "Kamchatka Standard Time" equals AKST + 21 hours.

KVERT: Kamchatkan Volcanic Eruption Response Team.

lapilli: pyroclasts or volcanic fragments that are between 2 and $64 \mathrm{~mm}$ in diameter.

lava: molten rock that has reached the Earth's surface.

magma: molten rock below the surface of the Earth.

METI: Japanese Ministry of Economy, Trade, and Industry.

MODIS: Satellite-based "Moderate-resolution Imaging Spectroradiometer."

MW0: Meteorological Watch Office.

NASA: National Aeronautics and Space Administration.

NOAA: National Oceanic and Atmospheric Administration.

NWS: National Weather Service.

OMI: Ozone Mapping Instrument on NASA's Aura satellite.

phreatic activity: an explosiveeruption caused by the sudden heating of groundwater as it comes in contact with hot volcanic rock or magma.

phreatic ash: fine fragments of volcanic rock expelled during phreatic activity; this ash usually is derived from existing rock and not from new magma.

PIREP: "Pilot Weather Report;" a report of meteorological phenomena encountered by aircraft in flight.

pixel: contraction of "picture element." A pixel is one of the many discrete rectangular elements that form a digital image or picture on a computer monitor or stored in memory. In a satellite image, resolution describes the size of a pixel in relation to area covered on the ground. More pixels per unit area on the ground means a higher resolution.

Pleistocene: geologic epoch extending from about 2.6 million years ago to approximately 10,000 years before present.
PUFF: a volcanic ash tracking model (see at URL: http://puff.images.alaska.edu/ monitoring.shtml).

pyroclast: an individual particle ejected during a volcanic eruption; usually classified by size, for example, ash, lapilli.

RSAM: Real-time Seismic-Amplitude Measurement.

regional earthquake:earthquakegenerated by fracture or slippage along a fault; not caused by volcanic activity.

SAR: Synthetic Aperture Radar.

satellite cone: a subsidiary volcanic vent located on the flank of a larger volcano.

seismic swarm: a flurry of closely spaced earthquakes or other ground shaking activity; often precedes an eruption.

shield volcano: a broad, gently sloping volcano usually composed of fluid lava flows of basalt composition (for example, Mauna Loa, Hawaii).

SI: Internation System of Units.

SIGMET: SIGnificant METeorological information statement, issued by NWS.

Stratovolcano: Also called a stratocone or composite cone, a steep-sided volcano, usually conical in shape, built of interbedded lava flows and fragmental deposits from explosive eruptions.

Strombolian: type of volcanic eruption characterized by intermittent bursts of fluid lava, usually basalt, from a vent or crater as gas bubbles risethrough a conduit and burstat the surface.

SVA: Suspect Volcanic Activity.

SVERT: "Sakhalin Volcanic Eruption Response Team" monitors and reports on Kurile Island volcanoes.

SWIR: Short Wave Infrared.

tephra: a general term covering all fragmental material expelled from a volcano (ash, bombs, cinders, etc.).

TFR: "Temporary Flight Restriction," issued by FAA.

TIR: Thermal Infrared.

UAFGI: University of Alaska Fairbanks Geophysical Institute.

USFWS: United States Fish and Wildlife Service. 
USGS: United States Geological Survey.

UTC: "Coordinated Universal Time"; same as Greenwich Mean Time (GMT).

UUA: Urgent pilot report.

VAAC: Volcanic Ash Advisory Center.

VAA: Volcanic Ash Advisory.

vent: an opening in the earth's surface through which magma erupts or volcanic gasses are emitted.
VNIR: Very Near Infrared.

volcano-tectonic earthquakes: earthquakes generated within or near a volcano from brittle rock failure resulting from strain induced by volcanic processes.

VT: volcano-tectonic. 
This page intentionally left blank. 


\section{Appendix 1. Volcano Alert Levels and Revised Aviation Color Codes Used by United States Volcano Observatories}

Alert levels address the overall activity at the volcano, not just the hazard to aviation. There may be situations where a volcano is producing lava flows that are dangerous on the ground and merit a WATCH or WARNING, however, the hazard to aviation is minimal. Alert level announcements contain additional explanation of volcanic activity and expected hazards where possible (Gardner and Guffanti, 2006).

\begin{tabular}{|c|l|}
\hline \multicolumn{2}{|c|}{ Alert Levels } \\
\hline NORMAL & $\begin{array}{l}\text { Typical background activity of a volcano in a non-eruptive state. } \\
\text { Or, after a change from a higher level: } \\
\text { Volcanic activity considered to have ceased and volcano reverted to its normal, non-eruptive state }\end{array}$ \\
\hline ADVISORY & $\begin{array}{l}\text { Elevated unrest above known background activity. } \\
\text { Or, after a change from a higher level: } \\
\text { Volcanic activity has decreased significantly but continues to be closely monitored for possible renewed increase. }\end{array}$ \\
\hline WATCH & $\begin{array}{l}\text { Volcano is exhibiting heightened or escalating unrest with increased potential for eruptive activity. } \\
\text { Or: } \\
\text { A minor eruption is underway that poses limited hazards. }\end{array}$ \\
\hline WARNING & Highly hazardous eruption underway or imminent. \\
\hline
\end{tabular}

\section{Level of Concern Codes for Aviation}

AVO will continue to use the color-coded level of concern designation that has been in place since 1990. Colors will now reflect only the hazards posed to the aviation community. Definitions of each color have changed slightly. Typically, this means that color codes indicate the likelihood or presence of airborne ash and ash clouds that threaten aircraft.

\begin{tabular}{|c|l|}
\hline \multirow{2}{*}{ GREEN } & $\begin{array}{l}\text { Volcano is in a normal, non-eruptive state. } \\
\text { Or, after a change from a higher level: } \\
\text { Volcanic activity considered to have ceased and volcano reverted to its normal, non-eruptive state }\end{array}$ \\
\hline \multirow{2}{*}{ YELLOW } & $\begin{array}{l}\text { Volcano is exhibiting signs of elevated unrest above known background levels. } \\
\text { Or, after a change from a higher level: } \\
\text { Volcanic activity has decreased significantly but continues to be closely monitored for possible renewed increase. }\end{array}$ \\
\hline \multirow{2}{*}{ ORANGE } & $\begin{array}{l}\text { Volcano is exhibiting heightened unrest with increased likelihood of eruption. } \\
\text { Volcanic eruption underway with no or minor ash emission. }\end{array}$ \\
& $\begin{array}{l}\text { Eruption is forecast to be imminent with significant emission of ash into the atmosphere likely. } \\
\text { Or: } \\
\text { Eruption is underway with significant emission of ash into the atmosphere. }\end{array}$
\end{tabular}




\section{Appendix 2. Level of Concern Color Code for Volcanic Activity Used in Kamchatka and the Kurile Islands in 2008}

\begin{tabular}{|c|l|}
\hline \multicolumn{2}{|l|}{ Level of Concern Color Code: Generic } \\
\hline GREEN & $\begin{array}{l}\text { No eruption anticipated. } \\
\text { Volcano is in quiet "dormant" state. }\end{array}$ \\
\hline YELLOW & $\begin{array}{l}\text { An eruption is possible in the next few weeks and may occur with little or no additional warning. } \\
\text { Small earthquakes detected locally and (or) increased levels of volcanic gas emissions. }\end{array}$ \\
\hline \multirow{2}{*}{ ORANGE } & $\begin{array}{l}\text { Explosive eruption is possible within a few days and may occur with little or no warning. Ash plume(s) not } \\
\text { expected to reach 25,000 feet above sea level. } \\
\text { Increase numbers of local earthquakes. Extrusion of a lava dome or lava flows (non-explosive eruption) may be } \\
\text { occurring. }\end{array}$ \\
\hline RED & $\begin{array}{l}\text { Major explosive eruption expected within } 24 \text { hours. Large ash plume(s) expected to reach at least } \\
\text { 25,000 feet above sea level. } \\
\text { Strong earthquake activity detected even at distant monitoring stations. Explosive eruption may be in progress. }\end{array}$ \\
\hline
\end{tabular}


Publishing support provided by the U.S. Geological Survey Publishing Network, Tacoma Publishing Service Center

For more information concerning the research in this report, contact the Director, Volcano Science Center

U.S. Geological Survey

4200 University Drive

Anchorage, Alaska 99508

http://volcanoes.usgs.gov/ 
Z

ํㅡㄹ

옴 